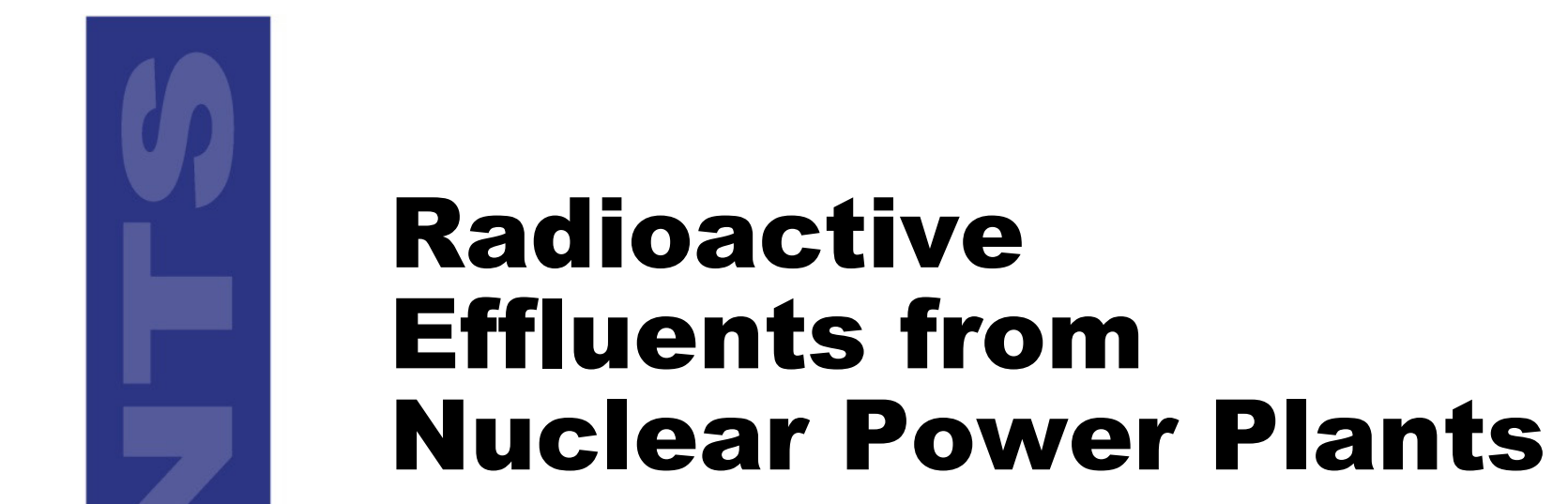

Annual Report 2007

Office of Nuclear Reactor Regulation U.S. Nuclear Regulatory Commission Washington, DC 20555-0001

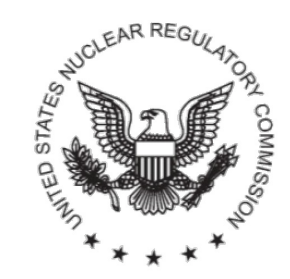


This page intentionally left blank 


\section{Radioactive Effluents}

\section{From Nuclear Power Plants}

\section{Annual Report 2007}

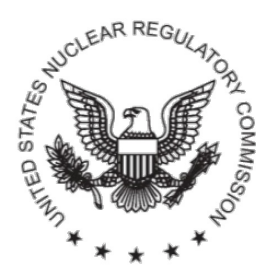

Prepared for

Office of Nuclear Reactor Regulation

U.S. Nuclear Regulatory Commission

Washington, DC 20555-0001 
This page intentionally left blank 


\section{ABSTRACT}

This report describes radioactive effluents from commercial nuclear power plants (NPPs) in the United States. This information was reported by the licensees for radioactive discharges that occurred in 2007. The report provides information relevant to the potential impact of NPPs on the environment and on public health. The report includes information on:

- radionuclides in liquid and gaseous effluents from NPPs and

- radiation doses to the public from NPP effluents.

This report is a summary of the effluent data reported by the NPPs. To view all the information contained in the Annual Radioactive Effluent Release Reports from each NPP, visit the Nuclear Regulatory Commission (NRC) Web site at http://www.nrc.gov/about-nrc/radiation.html.

The radionuclide and radiation dose data in this report are intended to provide the reader with a means to quickly characterize the effluents from any NPP. The data presented are considered by the NRC to be particularly relevant to the potential impact of NPPs on public health and the environment. The radionuclides selected for inclusion are either the most predominant in radioactive effluents or are particularly useful indicators of overall releases. The radiation doses in the report are those most directly associated with potential public health impact.

For purposes of comparison, the data also include the median (midpoint) radionuclide concentrations, as well as the applicable NRC dose limits and design objectives. Finally, the results of the National Council on Radiation Protection's assessment of radiation exposure to the U.S. population also are included so the reader can compare the dose from NPP effluents relative to natural background and other sources of radiation exposure. 
This page intentionally left blank 


\section{TABLE OF CONTENTS}

ABSTRACT

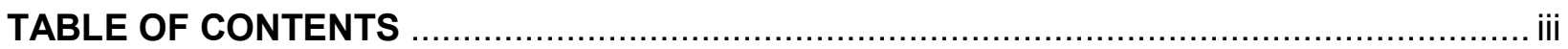

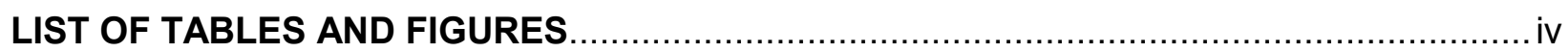

ABBREVIATIONS

1 INTRODUCTION

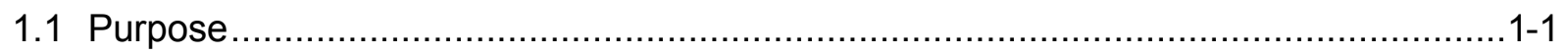

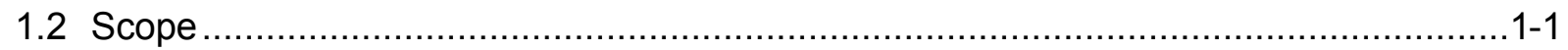

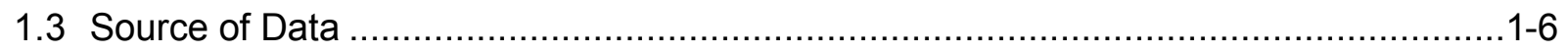

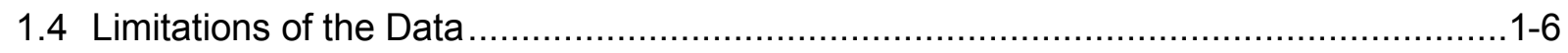

2 DESCRIPTION OF THE DATA

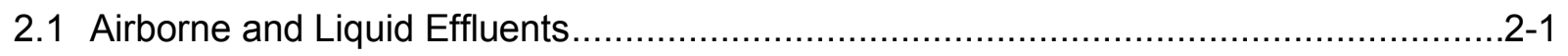

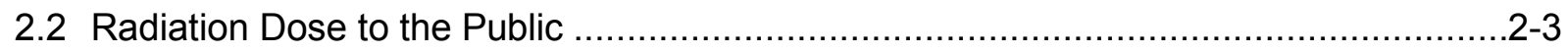

2.3 Other Sources of Radiation Dose to the U.S. Population .........................................2-4

3 SUMMARY

4 TABLES AND GRAPHS

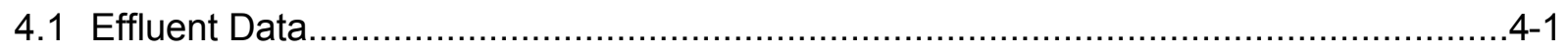

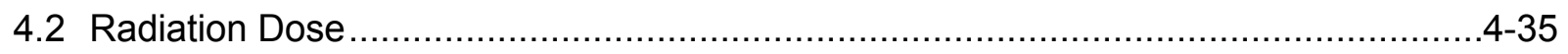

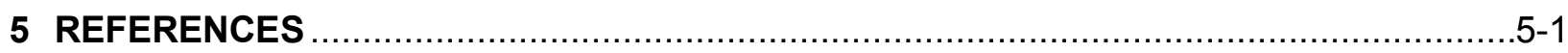

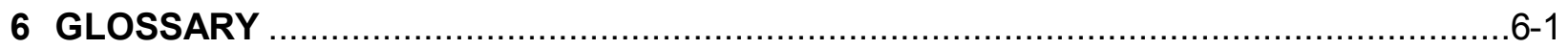




\section{LIST OF TABLES AND FIGURES}

\section{TABLES}

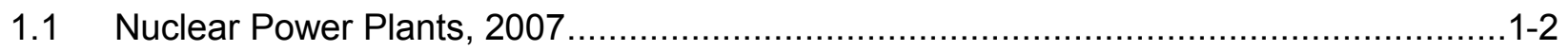

1.2 Reactors for Which the NRC Has Normalized Data on a Unit-specific Basis .................1-8

2.1 Radionuclides in Gaseous Effluents, 2007 ...........................................................

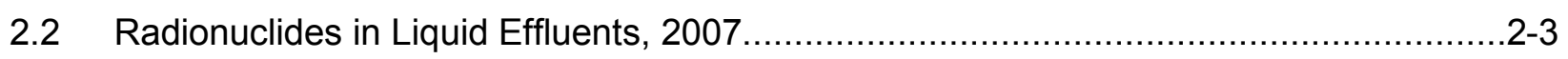

4.1 BWR Gaseous Releases — Selected Fission and Activation Gases, 2007 …................4-1

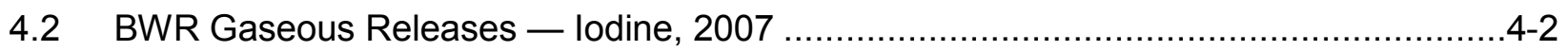

4.3 BWR Gaseous Releases — Selected Particulates, 2007 …........................................4-3

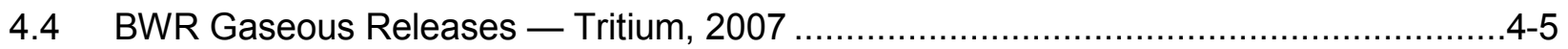

4.5 PWR Gaseous Releases — Selected Fission and Activation Gases, 2007 ....................4-6

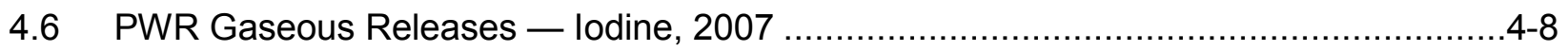

4.7 PWR Gaseous Releases — Selected Particulates, 2007 ..........................................4-9

4.8 PWR Gaseous Releases — Tritium, 2007 ....................................................

4.9 BWR Liquid Releases - Selected Fission and Activation Products, 2007 ...................4-12

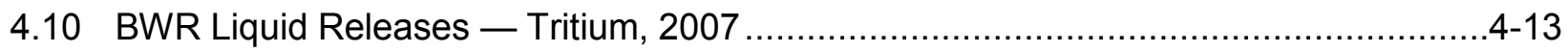

4.11 PWR Liquid Releases — Selected Fission and Activation Products, 2007 ...................4-14

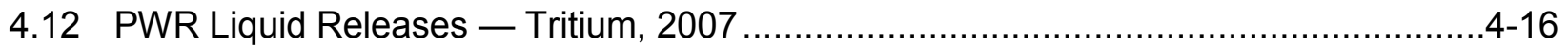

4.13 BWR Gaseous Effluents — Maximum Annual Organ Dose, 2007 ……….................4-35

4.14 PWR Gaseous Effluents — Maximum Annual Organ Dose, 2007 …..........................4-36

4.15 BWR Liquid Effluents — Maximum Annual Total Body and Organ Dose, 2007 ............4-37

4.16 PWR Liquid Effluents - Maximum Annual Total Body and Organ Dose, 2007 ............4-38 


\section{FIGURES}

2.1 Sources of Radiation Exposure to the U.S. Population ……..................................

4.1 BWR Gaseous Releases — Selected Fission and Activation Gases .........................4-17

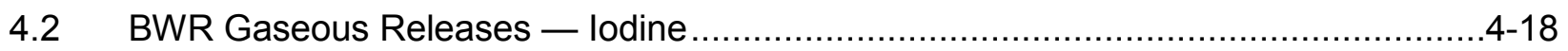

4.3 BWR Gaseous Releases — Selected Particulates .................................................4-19

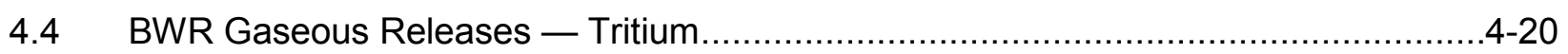

4.5 PWR Gaseous Releases — Selected Fission and Activation Gases .........................4-21

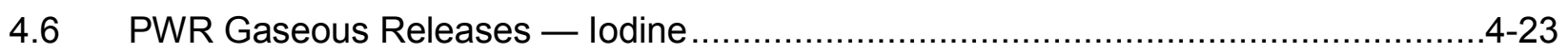

4.7 PWR Gaseous Releases — Selected Particulates ................................................ 4-25

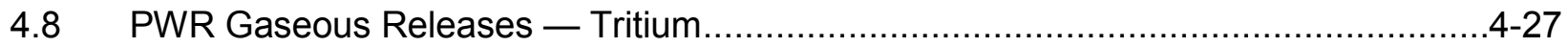

4.9 BWR Liquid Releases — Selected Fission and Activation Products ..........................4-29

4.10 BWR Liquid Releases — Tritium ...........................................................

4.11 PWR Liquid Releases — Selected Fission and Activation Products .........................4-31

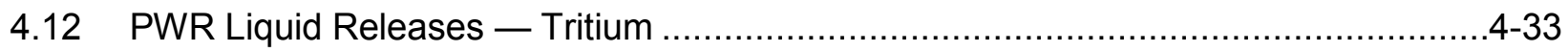

4.13 BWR Gaseous Effluents — Maximum Annual Organ Dose ....................................4-39

4.14 PWR Gaseous Effluents — Maximum Annual Organ Dose .....................................4-40

4.15 BWR Liquid Effluents - Maximum Annual Total Body and Organ Dose ...................4-42

4.16 PWR Liquid Effluents - Maximum Annual Total Body and Organ Dose ...................4-43 


\section{ABBREVIATIONS}

ALARA

ARERR

BWR

CFR

NCRP

NPP

NRR

ODCM

PWR

(U.S.) EPA

(U.S.) NRC as low as is reasonably achievable

Annual Radioactive Effluent Release Report

boiling water reactor

Code of Federal Regulations

National Council on Radiation Protection and Measurements

nuclear power plant

U.S. NRC, Office of Nuclear Reactor Regulation

Offsite Dose Calculation Manual

pressurized water reactor

United States Environmental Protection Agency

United States Nuclear Regulatory Commission 


\section{Section 1 INTRODUCTION}

\subsection{PURPOSE}

This report describes radioactive effluents from commercial nuclear power plants (NPPs) in the United States during calendar year 2007. It is based on an extensive amount of information submitted to the Nuclear Regulatory Commission (NRC) by all U.S. NPP licensees. The original information was submitted by the NPPs in their Annual Radioactive Effluent Release Reports (ARERRs) and comprises several thousand pages of data. These reports may be viewed in their entirety on the NRC Web site (http://www.nrc.gov/about-nrc/radiation.html).

For the years between 1972 and 1993, this type of annual information was condensed in a tabular format and published as a large volume of raw information (Ref. 1-22). An evaluation of the practice of generating annual reports revealed the need for a more concise summary report that presented the information in a more intuitive, graphic format (Ref. 23).

The purpose of this report is to condense an extremely large volume of technical information into a few graphs and tables from which the reader can quickly, if broadly, characterize the effluents from any U.S. NPP. These graphs and tables are designed to provide easily understandable information for the public at large, while also providing experienced professionals with enough information to evaluate trends in industry performance and to identify potential performance issues for individual power plants. Those users wanting more extensive and detailed information are encouraged to retrieve the original ARERRs from the NRC Web site.

\subsection{SCOPE}

This report summarizes data from all NPPs that were in commercial operation between January 1, 2007 and December 31, 2007. A list of NPPs for which information is included in this report is provided in Table 1.1. 
TABLE 1.1

Nuclear Power Plants, 2007

\begin{tabular}{|c|c|c|c|}
\hline Plant Name & Type & Full Plant Name & Location \\
\hline Arkansas $1 \& 2$ & PWR & $\begin{array}{l}\text { Arkansas Nuclear One (ANO), } \\
\text { Units } 1 \& 2\end{array}$ & Russellville, AR \\
\hline Beaver Valley 1 \& 2 & PWR & Beaver Valley, Units $1 \& 2$ & Shippingport, PA \\
\hline Braidwood 1 \& 2 & PWR & $\begin{array}{l}\text { Braidwood Generating Station, } \\
\text { Units } 1 \& 2\end{array}$ & Braceville, IL \\
\hline Browns Ferry 1, 2, \& 3 & BWR & $\begin{array}{l}\text { Browns Ferry Nuclear Plant, } \\
\text { Units } 1,2, \& 3\end{array}$ & Decatur, AL \\
\hline Brunswick $1 \& 2$ & BWR & $\begin{array}{l}\text { Brunswick Steam Electric Plant, } \\
\text { Units } 1 \& 2\end{array}$ & Southport, NC \\
\hline Byron $1 \& 2$ & PWR & $\begin{array}{l}\text { Byron Generating Station, } \\
\text { Units } 1 \& 2\end{array}$ & Byron, IL \\
\hline Callaway & PWR & Callaway Plant, Unit 1 & Callaway, MO \\
\hline Calvert Cliffs 1, 2 & PWR & $\begin{array}{l}\text { Calvert Cliffs Nuclear Power } \\
\text { Plant, Units } 1 \& 2\end{array}$ & Lusby, MD \\
\hline Catawba 1, 2 & PWR & $\begin{array}{l}\text { Catawba Nuclear Station, } \\
\text { Units } 1 \& 2\end{array}$ & York, SC \\
\hline Clinton & BWR & Clinton Power Station & Clinton, IL \\
\hline Columbia Generating & BWR & Columbia Generating Station & Richland, WA \\
\hline Comanche Peak 1, 2 & PWR & $\begin{array}{l}\text { Comanche Peak Steam Electric } \\
\text { Station, Units } 1 \& 2\end{array}$ & Glen Rose, TX \\
\hline Cook 1, 2 & PWR & $\begin{array}{l}\text { Donald C. Cook Nuclear Plant, } \\
\text { Units } 1 \& 2\end{array}$ & Bridgman, MI \\
\hline Cooper Station & BWR & Cooper Nuclear Station & Brownville, NE \\
\hline Crystal River 3 & PWR & Crystal River, Unit 3 & Crystal River, FL \\
\hline Davis-Besse & PWR & $\begin{array}{l}\text { Davis-Besse Nuclear Power } \\
\text { Station, Unit } 1\end{array}$ & Oak Harbor, OH \\
\hline Diablo Canyon 1, 2 & PWR & Diablo Canyon, Units $1 \& 2$ & Avila Beach, CA \\
\hline Dresden 2, 3 & BWR & $\begin{array}{l}\text { Dresden Generating Station, } \\
\text { Units } 2 \& 3\end{array}$ & Morris, IL \\
\hline Duane Arnold & BWR & Duane Arnold Energy Center & Palo, IA \\
\hline Farley 1 \& 2 & PWR & $\begin{array}{l}\text { Joseph M. Farley Nuclear Plant, } \\
\text { Units } 1 \& 2\end{array}$ & Ashford, AL \\
\hline Fermi 2 & BWR & Fermi 2 Nuclear Power Plant & Newport, MI \\
\hline
\end{tabular}


TABLE 1.1 (continued)

Nuclear Power Plants, 2007

\begin{tabular}{|c|c|c|c|}
\hline Plant Name & Type & Full Plant Name & Location \\
\hline Fitzpatrick & BWR & $\begin{array}{l}\text { James A. FitzPatrick } \\
\text { Nuclear Power Plant }\end{array}$ & Lycoming, NY \\
\hline Fort Calhoun & PWR & Fort Calhoun Station, Unit 1 & Fort Calhoun, NE \\
\hline Ginna & PWR & R.E. Ginna Nuclear Power Plant, Unit 1 & Ontario, NY \\
\hline Grand Gulf & BWR & $\begin{array}{l}\text { Grand Gulf Nuclear Station, } \\
\text { Unit } 1\end{array}$ & Port Gibson, MS \\
\hline Harris & PWR & $\begin{array}{l}\text { Shearon Harris Nuclear Power Plant, } \\
\text { Unit } 1\end{array}$ & New Hill, NC \\
\hline Hatch 1, 2 & BWR & $\begin{array}{l}\text { Edwin I. Hatch Nuclear Plant, Units } 1 \text { \& } \\
2\end{array}$ & Baxley, GA \\
\hline Hope Creek & BWR & Hope Creek Generating Station, Unit 1 & Hancocks Bridge, NJ \\
\hline Indian Point 2, 3 & PWR & $\begin{array}{l}\text { Indian Point Energy Center, } \\
\text { Units } 2 \& 3\end{array}$ & Buchanan, NY \\
\hline Kewaunee & PWR & Kewaunee Power Station & Kewaunee, WI \\
\hline LaSalle 1, 2 & BWR & $\begin{array}{l}\text { LaSalle County Generating Station, } \\
\text { Units } 1 \text { \& } 2\end{array}$ & Marseilles, IL \\
\hline Limerick 1, 2 & BWR & Limerick Generating Station, Units 1 \& 2 & Saratoga, PA \\
\hline McGuire 1, 2 & PWR & $\begin{array}{l}\text { McGuire Nuclear Station, } \\
\text { Units } 1 \& 2\end{array}$ & Huntersville, NC \\
\hline Millstone 2, 3 & PWR & Millstone Power Station, Units 2 \& 3 & Waterford, CT \\
\hline Monticello & BWR & Monticello Nuclear Generating Plant & Monticello, MN \\
\hline Nine Mile Point 1, 2 & BWR & $\begin{array}{l}\text { Nine Mile Point Nuclear Station, Units } 1 \\
\& 2\end{array}$ & Lycoming, NY \\
\hline North Anna 1, 2 & PWR & $\begin{array}{l}\text { North Anna Power Station, } \\
\text { Units } 1 \& 2\end{array}$ & Mineral, VA \\
\hline Oconee 1, 2, 3 & PWR & $\begin{array}{l}\text { Oconee Nuclear Station, } \\
\text { Units } 1,2, \& 3\end{array}$ & Seneca, SC \\
\hline
\end{tabular}


TABLE 1.1 (continued)

Nuclear Power Plants, 2007

\begin{tabular}{|c|c|c|c|}
\hline Plant Name & Type & Full Plant Name & Location \\
\hline Oyster Creek & BWR & $\begin{array}{l}\text { Oyster Creek Nuclear Generating } \\
\text { Station }\end{array}$ & Forked River, NJ \\
\hline Palisades & PWR & Palisades Nuclear Plant & Covert, MI \\
\hline Palo Verde 1, 2, 3 & PWR & $\begin{array}{l}\text { Palo Verde Nuclear Generating Station, } \\
\text { Units } 1,2, \& 3\end{array}$ & Phoenix, AZ \\
\hline Peach Bottom 2, 3 & BWR & $\begin{array}{l}\text { Peach Bottom Atomic Power Station, } \\
\text { Units } 2 \text { \& } 3\end{array}$ & Delta, PA \\
\hline Perry & BWR & $\begin{array}{l}\text { Perry Nuclear Power Plant, } \\
\text { Unit } 1\end{array}$ & Perry, OH \\
\hline Pilgrim & BWR & Pilgrim Nuclear Power Station, Unit 1 & Plymouth, MA \\
\hline Point Beach 1, 2 & PWR & $\begin{array}{l}\text { Point Beach Nuclear Plant, } \\
\text { Units } 1 \& 2\end{array}$ & Two Rivers, WI \\
\hline Prairie Island 1, 2 & PWR & $\begin{array}{l}\text { Prairie Island Nuclear Generating Plant, } \\
\text { Units } 1 \& 2\end{array}$ & Welch, MN \\
\hline Quad Cities 1, 2 & BWR & $\begin{array}{l}\text { Quad Cities Generating Station, Units } 1 \\
\& 2\end{array}$ & Cordova, IL \\
\hline River Bend & BWR & River Bend Station, Unit 1 & St. Francisville, LA \\
\hline Robinson 2 & PWR & $\begin{array}{l}\text { H. B. Robinson Steam Electric Plant, } \\
\text { Unit } 2\end{array}$ & Hartsville, SC \\
\hline Salem 1, 2 & PWR & $\begin{array}{l}\text { Salem Nuclear Generating Station, } \\
\text { Units } 1 \& 2\end{array}$ & Hancocks Bridge, NJ \\
\hline San Onofre 2, 3 & PWR & $\begin{array}{l}\text { San Onofre Nuclear Generating Station, } \\
\text { Units } 2 \& 3\end{array}$ & San Clemente, CA \\
\hline Seabrook & PWR & Seabrook Station, Unit 1 & Seabrook, NH \\
\hline Sequoyah 1,2 & PWR & $\begin{array}{l}\text { Sequoyah Nuclear Plant, } \\
\text { Units } 1 \& 2\end{array}$ & Soddy-Daisy, TN \\
\hline South Texas 1, 2 & PWR & $\begin{array}{l}\text { South Texas Project Electric Generating } \\
\text { Station, Units } 1 \& 2\end{array}$ & Wadsworth, TX \\
\hline St. Lucie 1, 2 & PWR & $\begin{array}{l}\text { St. Lucie Nuclear Plant, } \\
\text { Units } 1 \text { \& } 2\end{array}$ & Ft. Pierce, FL \\
\hline Summer & PWR & Virgil C. Summer Nuclear Station, Unit 1 & Jenkinsville, SC \\
\hline Surry 1,2 & PWR & Surry Power Station, Units $1 \& 2$ & Surry, VA \\
\hline Susquehanna 1, 2 & BWR & $\begin{array}{l}\text { Susquehanna Steam Electric Station, } \\
\text { Units } 1 \& 2\end{array}$ & Berwick, PA \\
\hline
\end{tabular}


TABLE 1.1 (continued)

Nuclear Power Plants, 2007

\begin{tabular}{|c|c|c|c|}
\hline Plant Name & Type & Full Plant Name & Location \\
\hline Three Mile Island 1 & PWR & $\begin{array}{l}\text { Three Mile Island Generating Station, } \\
\text { Unit } 1\end{array}$ & Harrisburg, PA \\
\hline Turkey Point 3, 4 & PWR & $\begin{array}{l}\text { Turkey Point Nuclear Plant, } \\
\text { Units } 3 \text { \& } 4\end{array}$ & Princeton, FL \\
\hline Vermont Yankee & BWR & Vermont Yankee Nuclear Plant, Unit 1 & Vernon, VT \\
\hline Vogtle 1, 2 & PWR & $\begin{array}{l}\text { Vogtle Electric Generating } \\
\text { Plant, Units } 1 \& 2\end{array}$ & Waynesboro, GA \\
\hline Waterford 3 & PWR & $\begin{array}{l}\text { Waterford Steam Electric Station, Unit } \\
3\end{array}$ & Killona, LA \\
\hline Watts Bar & PWR & Watts Bar Nuclear Plant, Unit 1 & Spring City, TN \\
\hline Wolf Creek & PWR & Wolf Creek Generating Station, Unit 1 & Burlington, KS \\
\hline \multicolumn{4}{|c|}{ Reactors No Longer In Commercial Operation } \\
\hline Big Rock Point & BWR & Big Rock Point Restoration Project & Charlevoix, MI \\
\hline Dresden 1 & BWR & Dresden Generating Station, Unit 1 & Morris, IL \\
\hline Haddam Neck & PWR & Haddam Neck Nuclear Plant Site & Haddam Neck, CT \\
\hline Humboldt Bay & BWR & $\begin{array}{l}\text { Humboldt Bay Power Plant, } \\
\text { Unit } 3\end{array}$ & Eureka, CA \\
\hline Indian Point 1 & PWR & $\begin{array}{l}\text { Indian Point Energy Center, } \\
\text { Unit } 1\end{array}$ & Buchanan, NY \\
\hline Lacrosse & BWR & LaCrosse Boiling Water Reactor & Genoa, WI \\
\hline Maine Yankee & PWR & Maine Yankee & Bath, ME \\
\hline Millstone 1 & PWR & $\begin{array}{l}\text { Millstone Power Station, } \\
\text { Unit } 1\end{array}$ & Waterford, CT \\
\hline Rancho Seco & PWR & Rancho Seco, Unit 1 & Herald, CA \\
\hline San Onofre 1 & PWR & $\begin{array}{l}\text { San Onofre Nuclear Generating } \\
\text { Station, Unit } 1\end{array}$ & San Clemente, CA \\
\hline Three Mile Island 2 & PWR & $\begin{array}{l}\text { Three Mile Island Nuclear Station, } \\
\text { Unit } 2\end{array}$ & Middletown, PA \\
\hline Trojan & PWR & Trojan Nuclear Plant, Unit 1 & Portland, OR \\
\hline Yankee-Rowe & PWR & Yankee Nuclear Power Station & Franklin Co., MA \\
\hline Zion 1, 2 & PWR & $\begin{array}{l}\text { Zion Generating Station, } \\
\text { Units } 1 \& 2\end{array}$ & Warrenville, IL \\
\hline
\end{tabular}


The NRC uses the information on radioactive releases to ensure NPPs are operated within regulatory requirements and consistent with the objective of maintaining radiation doses as low as is reasonably achievable (ALARA). For this summary report, only information submitted with regard to NRC reporting requirements and guidance is included.

The Big Rock Point, Haddam Neck, Humboldt Bay, Lacrosse, Maine Yankee, Rancho Seco, Trojan, Yankee-Rowe and Zion 1 and 2 reactor sites are shutdown and are not collocated with an operating reactor. The data from these shutdown reactors are not included in the tables in this report. The Dresden 1, Millstone 1, and Three Mile Island 2 reactors are shutdown and are collocated with one of more operating reactors. For these shutdown reactors, the licensee reports data for the shutdown unit separately from the operating units, and the results from these shutdown reactors are not included in this report. For the Indian Point 1 and San Onofre 1 reactor sites, which are shutdown and collocated beside two operating units, the licensee reports the sum of the effluents from the shutdown unit with one (or both) of the operating units. For these shutdown reactors, the effluent data are included with (and attributed to) one or more of the operating units in this report.

\subsection{SOURCE OF DATA}

Each commercial nuclear power plant in the United States is authorized by the NRC to release small amounts of radioactive materials to the environment as specified in the licensing documents for the plant. NRC regulations require each NPP to establish and maintain a program for monitoring radioactive effluents (10 CFR 50.36 and 10 CFR 50, Appendix I, Section IV.B) and to report these effluents in an Annual Radioactive Effluent Release Report (10 CFR 50.36a) (Ref. 24). Licensees submit their reports to the NRC with content and format in accordance with Regulatory Guide 1.21 (Ref. 25).

The information included in this document was obtained from the licensees' ARERRs. Individual licensee reports are available in the NRC Public Document Room, One White Flint North, 11555 Rockville Pike (first floor), Rockville, Maryland 20852, phone 1-800-397-4209 or 301-415-4737; in local Public Document Rooms located near each licensed facility; and on the Internet as posted on the NRC's public Web site at http://www.nrc.gov/about-nrc/radiation.html.

The data from these reports are entered into a database that is maintained by the NRC. The public may access this database through an NRC Web site (http://www.reirs.com/effluent/). The data are entered into the database as they are reported by each site.

\subsection{LIMITATIONS OF THE DATA}

Some NPPs have more than one reactor unit located at a site. If the licensee reports data separately for each reactor unit, those data are reflected in this report as reported by the licensee. Because some licensees are allowed to operate multi-unit sites with a common radioactive waste processing system, the NRC allows these licensees to report total effluents 
from the site instead of reporting the totals from each reactor unit. This complicates the task of presenting the effluent information in a manner that allows both (1) a direct comparison of one reactor unit to another, and (2) a direct comparison of each reactor unit to NRC limits and regulations.

For purposes of presentation in this report, the data are normalized on a per-unit basis. For multi-unit sites where the effluents are from a common radioactive waste system, the effluents are divided equally between the units in operation during that year. For example, Calvert Cliffs has two units ( 1 and 2 ) with a common radioactive waste processing system. For this report, the total effluents for Calvert Cliffs were split equally between Unit 1 and Unit 2. In the case of Beaver Valley, the licensee reports gaseous effluents from four sources: Unit 1, Unit 2, a common plant vent, and a common building vent. In this case, the releases from the common vents are split equally between Unit 1 and Unit 2, and the totals for each unit then are calculated. In those cases where the licensee does not report unit-specific data, the NRC has for purposes of presentation in this report - split the data on a unit-specific basis. This may affect either the radionuclide data or the dose data (or both). The affected NPPs and the type of data affected are listed in table 1-2.

Although there are other methods of normalizing effluent data (e.g., on the basis of thermal or electrical power generation), the unit-based method selected (1) is most intuitive, (2) is most directly comparable with the NRC required design objectives, and (3) is easily derived from the effluent data supplied by the licensee. This approach satisfies a primary objective for this report: to allow the reader to quickly formulate reasonable comparisons between reactors and with the regulatory limits. It should be noted, however, that the actual unit contributions to a common multi-unit release might be different than the equal distribution calculated with this approach.

Care has been taken to assure that the information contained in this report accurately reflects the information provided by the licensees. The report includes licensees' corrections submitted to the NRC up to the time of publication. However, if licensees submit amendments to the data in accordance with NRC regulatory guidance, the NRC reserves the right to update the data in future reports. For the most current data, the reader should use the most recent versions of the NPPs' ARERRs and the NRC's annual summary report, which are available on the NRC Web site. 
TABLE 1.2

Reactors for Which the NRC Has Normalized Data on a Unit-specific Basis

\begin{tabular}{|c|c|}
\hline $\begin{array}{c}\text { Boiling Water } \\
\text { Reactors (BWRs) }\end{array}$ & $\begin{array}{l}\text { Pressurized Water } \\
\text { Reactors (PWRs) }\end{array}$ \\
\hline $\begin{array}{l}\text { Browns Ferry } \\
1,2 \& 3(R, D)\end{array}$ & $\begin{array}{l}\text { Beaver Valley } \\
1 \& 2(R)\end{array}$ \\
\hline $\begin{array}{l}\text { Brunswick } \\
1 \& 2(R, D)\end{array}$ & $\begin{array}{l}\text { Calvert Cliffs } \\
1 \& 2(R, D)\end{array}$ \\
\hline $\begin{array}{l}\text { Dresden } \\
2 \& 3(\mathrm{R})\end{array}$ & $\begin{array}{l}\text { Catawba } \\
1 \& 2(R, D)\end{array}$ \\
\hline $\begin{array}{l}\text { LaSalle } \\
1 \& 2(R, D)\end{array}$ & $\begin{array}{l}\text { Comanche Peak } \\
1 \& 2(R, D)\end{array}$ \\
\hline $\begin{array}{l}\text { Limerick } \\
1 \text { \& } 2 \text { (R, D) }\end{array}$ & $\begin{array}{l}\text { Cook } \\
1 \& 2(R, D)\end{array}$ \\
\hline $\begin{array}{l}\text { Nine Mile Point } \\
1 \& 2 \text { (D) }\end{array}$ & $\begin{array}{l}\text { Diablo Canyon } \\
1 \& 2(\mathrm{R})\end{array}$ \\
\hline $\begin{array}{l}\text { Peach Bottom } \\
2 \& 3(R, D)\end{array}$ & $\begin{array}{l}\text { Indian Point } \\
1 \& 2(R, D)\end{array}$ \\
\hline $\begin{array}{l}\text { Quad Cities } \\
1 \& 2(R, D)\end{array}$ & $\begin{array}{l}\text { McGuire } \\
1 \text { \& } 2 \text { (R, D) }\end{array}$ \\
\hline \multirow[t]{8}{*}{$\begin{array}{l}\text { Susquehanna } \\
1 \& 2(R)\end{array}$} & $\begin{array}{l}\text { North Anna } \\
1 \& 2(R, D)\end{array}$ \\
\hline & $\begin{array}{l}\text { Oconee } \\
1,2 \& 3(R, D)\end{array}$ \\
\hline & $\begin{array}{l}\text { Point Beach } \\
1 \& 2(R, D)\end{array}$ \\
\hline & $\begin{array}{l}\text { Prairie Island } \\
1 \& 2(R, D)\end{array}$ \\
\hline & $\begin{array}{l}\text { Salem } \\
1 \& 2(D)\end{array}$ \\
\hline & $\begin{array}{l}\text { San Onofre } \\
2 \& 3(R, D)\end{array}$ \\
\hline & $\begin{array}{l}\text { Sequoyah } \\
1 \& 2(R, D)\end{array}$ \\
\hline & $\begin{array}{l}\text { Surry } \\
1 \& 2(R, D)\end{array}$ \\
\hline
\end{tabular}

Notes:

$R=$ Radionuclide Data, $D=$ Dose Data 


\section{Section 2}

DESCRIPTION OF THE DATA

\subsection{AIRBORNE AND LIQUID EFFLUENTS}

The effluent data are presented in Section 4 as tables and graphs. Tables 4.1 through 4.12 list the total measured activities of selected radionuclides in gaseous and liquid effluents during 2007. These data are illustrated in Figures 4.1 through 4.12. If there is no value listed in a particular cell in a table, it is because the licensee indicated the radionuclide was not detected at that NPP. In those cases, the corresponding graph will not contain information on that radionuclide at that NPP.

For comparison purposes, median values are included on some tables and graphs. The median is a statistical estimate of the midpoint of the data. It is a method of estimating a central or typical value while avoiding bias caused by extremely high or low values in the data set. All sites are included when calculating the medians, even those sites for which no measurable release of a particular radionuclide is reported. If the majority of reactors did not detect a nuclide, the median will be blank.

The tables and graphs are organized by reactor type: boiling water reactors (BWRs) and pressurized water reactors (PWRs). The tables and graphs are further subdivided into liquid and gaseous effluents. Finally, the data are subdivided into effluent radionuclide categories.

In order to present the airborne and liquid effluent data in a manner that is both useful and concise, only selected radionuclides are included in the tables and graphs of this report. The radionuclides included are listed by effluent category in Tables 2.1 and 2.2.

The unit used for calculating and reporting effluent activity is the curie (Ci), a traditional unit for reporting radioactivity in the United States. Other countries report radionuclide activity in units of becquerels $(\mathrm{Bq})$. One curie equals $3.7 \mathrm{E}+10\left(3.7 \times 10^{10}\right)$ becquerels. 
TABLE 2.1

Radionuclides in Gaseous Effluents, 2007

\begin{tabular}{|c|c|c|}
\hline $\begin{array}{l}\text { Gaseous Effluent } \\
\text { Categories }\end{array}$ & $\begin{array}{l}\text { Some Common Radionuclides in } \\
\text { this Category }\end{array}$ & $\begin{array}{l}\text { Radionuclides Included } \\
\text { in this Report }\end{array}$ \\
\hline $\begin{array}{l}\text { Fission and } \\
\text { Activation Gases }\end{array}$ & $\begin{array}{l}\text { Krypton }(85,85 \mathrm{~m}, 87,88) \\
\text { Xenon }(131,131 \mathrm{~m}, 133,133 \mathrm{~m}, \\
135,135 \mathrm{~m}) \\
\text { Argon }(41)\end{array}$ & $\begin{array}{l}\mathrm{Kr}-85 \\
\mathrm{Xe}-133 \\
\mathrm{Xe}-135\end{array}$ \\
\hline lodines/Halogens & $\begin{array}{l}\text { Iodine }(131,132,133,134,135) \\
\text { Bromine }(82)\end{array}$ & I-131 \\
\hline Particulates & $\begin{array}{l}\text { Cobalt }(58,60) \\
\text { Cesium }(134,137) \\
\text { Chromium }(51) \\
\text { Manganese }(54) \\
\text { Niobium }(95)\end{array}$ & $\begin{array}{l}\text { Co-58 } \\
\text { Co-60 } \\
\text { Cs-134 } \\
\text { Cs-137 }\end{array}$ \\
\hline Tritium & Hydrogen (3) & $\mathrm{H}-3$ \\
\hline Gross Alpha & $\begin{array}{l}\text { Total alpha activity from all } \\
\text { alpha emitters }\end{array}$ & Not Presented in this Report \\
\hline
\end{tabular}

The radionuclides highlighted in this report are good indicators of total radioactive releases from the site, and they can provide additional information about operational practices at the site. For example, although there are more than 11 radionuclides in the category of "fission and activation gases," only 3 (Kr-85, Xe-133, and Xe-135) were selected for inclusion in this report. These three were chosen because as their activity increases, the activity of other fission and activation gases typically increases as well. Conversely, if the activity of these three radionuclides is very low, the activity of other fission and activation gases tends to be low also.

In addition, the ratios of the activities of selected radionuclides can provide insights into fuel performance, radioactive waste system operation, and general radioactive waste handling practices at a site. The interested reader wanting to see all radionuclides released from NPPs is encouraged to review the detailed, site-specific ARERRs on the NRC Web site. 
TABLE 2.2

Radionuclides in Liquid Effluents, 2007

\begin{tabular}{|c|c|c|}
\hline $\begin{array}{l}\text { Liquid Effluent } \\
\text { Categories }\end{array}$ & $\begin{array}{l}\text { Some Common Radionuclides in } \\
\text { this Category }\end{array}$ & $\begin{array}{l}\text { Radionuclides Included } \\
\text { in this Report }\end{array}$ \\
\hline $\begin{array}{l}\text { Mixed Fission and } \\
\text { Activation Products }\end{array}$ & $\begin{array}{l}\text { Iron }(55) \\
\text { Cobalt }(58,60) \\
\text { Cesium }(134,137) \\
\text { Chromium }(51) \\
\text { Manganese }(54) \\
\text { Zirconium }(95) \\
\text { Niobium }(95) \\
\text { lodine }(131,133,135)\end{array}$ & $\begin{array}{l}\text { Fe-55 } \\
\text { Co-58 } \\
\text { Co-60 } \\
\text { Cs-134 } \\
\text { Cs-137 } \\
\text { I-131 }\end{array}$ \\
\hline Tritium & Hydrogen (3) & $\mathrm{H}-3$ \\
\hline $\begin{array}{l}\text { Dissolved and } \\
\text { Entrained Noble } \\
\text { Gases }\end{array}$ & $\begin{array}{l}\text { Krypton }(85,85 \mathrm{~m}, 87,88) \\
\text { Xenon }(131,133,133 \mathrm{~m}, 135,135 \mathrm{~m})\end{array}$ & Not Presented in this Report \\
\hline Alpha & $\begin{array}{l}\text { Total alpha activity from all alpha } \\
\text { emitters }\end{array}$ & Not Presented in this Report \\
\hline
\end{tabular}

\subsection{RADIATION DOSE TO THE PUBLIC}

Each licensee calculates radiation doses from radioactive effluents in accordance with requirements of 10 CFR 50, Appendix I, (Ref. 24) based on:

1. actual measurements of the radioactive materials released to the environment,

2. models of how radionuclides are dispersed and diluted in the environment,

3. models of how radionuclides are incorporated into animals, plants, and soil, and

4. biokinetic models of human uptake and metabolism of radioactive materials.

These models are designed to calculate the doses to the individuals closest to the NPP or the individuals who may be exposed to the highest concentrations of radioactive materials from radioactive effluents. This is often referred to as the maximum exposed individual. The parameters and assumptions used in these calculations typically include conservative assumptions that tend to overestimate the calculated exposures. As a result, the actual doses received by real individuals are often much less than those calculated. Guidance for these calculations is provided in NRC Regulatory Guide 1.109, and licensees have incorporated this 
guidance into their Offsite Dose Calculation Manuals (ODCM) (Ref. 26). ODCMs are available in the NRC Public Document Room and in local Public Document Rooms (e.g., public libraries) located near each NPP. The interested reader may refer to these documents for additional information about dose calculations.

The traditional unit for reporting radiation dose in the United States is the millirem (mrem). Other countries report radiation dose in units of sieverts (Sv). One millirem equals 0.00001 sievert. The number 0.00001 is often represented in scientific notation as $1 \times 10^{-5}$ or $1 \mathrm{E}-05$.

Once the doses are calculated as described in the preceding paragraphs, the calculated doses are compared to the operating limits for a NPP. Licensees have established operating limits for plant systems to control the amounts of radioactive materials released from NPPs. The NRC requires these operating limits to be established in accordance with the design objectives in 10 CFR 50, Appendix I (Ref. 24). These operating limits are designed to ensure radioactive effluents from NPPs are kept as low as is reasonably achievable (ALARA). It should be understood that these are operating limits for plant systems and are not safety limits. If a licensee would exceed one of these operating limits, they are required to take corrective actions to ensure the plant systems are functioning as designed. Maintaining the design functions of plant systems is critical to ensure radioactive releases do not exceed the dose limits in 10 CFR 20 (which are federal safety limits) (Ref. 27). For purposes of comparison, the operating limits are set to a small fraction (typically about $3 \%$ ) of the federal safety limits. Licensees have incorporated several different operating limits into their ODCMs as required by their Technical Specifications to satisfy NRC regulatory requirements.

Radiation doses from plant effluents are summarized in Section 4 (Tables 4.13 through 4.16 and Figures 4.13 through 4.16). These graphs and figures contain the annual organ doses (for gaseous and liquid effluents), the annual total body doses (for liquid effluents), and the corresponding operating limits. These doses are measures of the potential impact of NPP effluents on public health and the environment. For multi-unit sites, the operating limits are established on a per-unit basis. If there is no value listed in a particular cell of a table, it is because the value was not reported by the licensee. In such cases, the corresponding graph will not contain dose information for that NPP. Although only the annual organ doses and the annual total body doses are included in this report, other doses calculated by the NPPs are included in the individual NPP ARERRs, available on the NRC Web site.

\subsection{OTHER SOURCES OF RADIATION DOSE TO THE U.S. POPULATION}

For comparison with NPP effluents, this section provides a perspective on the doses that Americans typically receive on average from natural and background radiation.

In March 2009, the National Council on Radiation Protection and Measurements (NCRP) published Report No. 160 as an update to the 1987 NCRP Report No. 93, lonizing Radiation Exposure of the Population of the United States (Refs. 28, 29). Report No. 160 describes the 
doses to the U.S. population from all sources of ionizing radiation for 2006 , the most recent data available at the time the report was written. The report also includes information on the variability of those doses from one individual to another. The NCRP estimated that the average person in the United States receives the equivalent of about 620 mrem of radiation dose each year. NCRP Report No. 160 describes each of the sources of radiation that contribute to this dose, including:

1. naturally-occurring sources (natural background) such as cosmic radiation from space, terrestrial radiation from radioactive materials in the earth, and naturally occurring radioactive materials in food people eat and air people breathe;

2. medical sources from diagnosis and treatment of health disorders using radioactive pharmaceuticals and radiation-producing equipment;

3. consumer products;

4. industrial processes, security devices, educational tools, and research activities;

5. exposures of workers that result from their occupations.

Figure 2.1 is a pie chart showing the relative contributions of these sources to radiation dose to the U.S. population. Larger relative contributors to dose are represented by proportionally larger slices of the pie. Doses to the public from nuclear power generation are included in the industrial category; doses to workers from nuclear power generation are included in the category of occupational dose.

Doses to the public due to effluents from NPPs are less than $0.1 \%$ of what the average person receives each year from all sources of radiation. Doses to workers from occupational exposures, including those received from work at NPPs, also are less than $0.1 \%$ of the average dose to a member of the public from all sources. 
FIGURE 2.1

Sources of Radiation Exposure to the U.S. Population

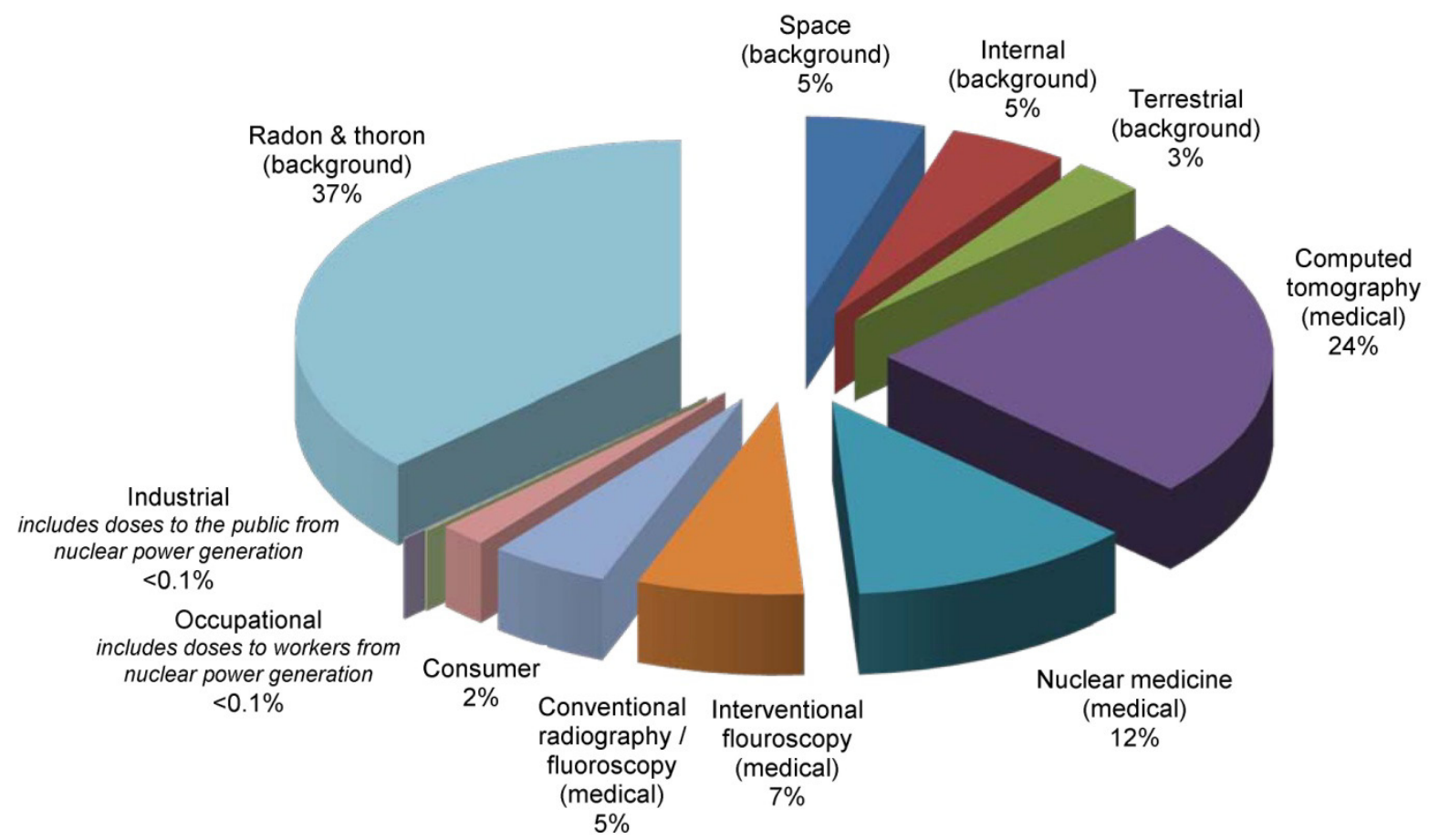

Percent contribution of various sources of exposure to the total collective effective dose and the total effective dose per individual in the U.S. population for 2006. Percent values have been rounded to the nearest $1 \%$, except for those $<1 \%$ [less than 1\%]. Credit: Modification to image courtesy of National Council on Radiation Protection and Measurements. 


\section{Section 3 \\ SUMMARY}

The effluent data from 2007 have been compiled and reported in the following section. The information contained in this report characterizes liquid and gaseous effluents from all United States nuclear power plants (NPPs) in commercial operation for calendar year 2007. Although all NPPs released some amount of radioactive materials in 2007, none of the effluents from any NPP exceeded any NRC limit, any NRC design objective, or any of the licensees' operating limits for radioactive effluents.

The effluent data provided in this report are considered by the NRC to be particularly relevant to the potential impact of the NPPs on public health and the environment. The radionuclides highlighted in this report are good indicators of the total radioactive releases from the site and they provide additional information about operational practices at a site. The radiation doses in this report are those most directly associated with potential public health impact from radioactive effluents.

The statistical medians of the effluent values, the corresponding operating limits, and the results of NCRP's assessment of radiation exposure to the U.S. population are provided for comparison to the effluent data. Comparisons between NPPs should be approached with caution because differences in fuel conditions, fuel cycle length, radwaste processing equipment, reactor types, reactor ages, electrical outputs, and operating conditions can have an effect on radioactive effluents.

More complete and detailed information, including copies of the NPP Annual Radioactive Effluent Release Reports, is available to the public on the NRC Web site. 
This page intentionally left blank 


\subsection{EFFLUENT DATA}

TABLE 4.1

BWR Gaseous Releases — Selected Fission and Activation Gases, 2007

\begin{tabular}{|c|c|c|c|c|c|c|c|}
\hline BWR Facility & $\begin{array}{l}\mathrm{Kr}-85 \\
(\mathrm{Ci})\end{array}$ & $\begin{array}{c}X e-133 \\
(C i)\end{array}$ & $\begin{array}{c}X e-135 \\
\text { (Ci) }\end{array}$ & BWR Facility & $\begin{array}{c}\mathrm{Kr}-85 \\
(\mathrm{Ci})\end{array}$ & $\begin{array}{c}X e-133 \\
(C i)\end{array}$ & $\begin{array}{c}\text { Xe-135 } \\
\text { (Ci) }\end{array}$ \\
\hline $\begin{array}{l}\text { Browns } \\
\text { Ferry } 1\end{array}$ & & & & Oyster Creek & & & $2.06 \mathrm{E}+01$ \\
\hline $\begin{array}{l}\text { Browns } \\
\text { Ferry } 2\end{array}$ & & & & Limerick 1 & $1.62 \mathrm{E}-01$ & $1.34 \mathrm{E}+01$ & $7.61 \mathrm{E}+00$ \\
\hline $\begin{array}{l}\text { Browns } \\
\text { Ferry } 3\end{array}$ & & & & Hope Creek & & $2.51 \mathrm{E}+01$ & $8.65 \mathrm{E}+00$ \\
\hline Clinton & & & & $\begin{array}{l}\text { Nine Mile } \\
\text { Point } 1\end{array}$ & & $3.42 \mathrm{E}+01$ & $2.75 \mathrm{E}+00$ \\
\hline Fermi 2 & & & & Dresden 2 & & $5.96 \mathrm{E}+00$ & $5.51 \mathrm{E}+01$ \\
\hline $\begin{array}{l}\text { Vermont } \\
\text { Yankee }\end{array}$ & & & & Dresden 3 & & $5.96 \mathrm{E}+00$ & $5.51 \mathrm{E}+01$ \\
\hline Hatch 1 & & & 4.62E-02 & Brunswick 1 & & $2.15 \mathrm{E}+01$ & $5.89 \mathrm{E}+01$ \\
\hline Hatch 2 & & & 4.62E-02 & Brunswick 2 & & $2.15 \mathrm{E}+01$ & $5.89 \mathrm{E}+01$ \\
\hline $\begin{array}{l}\text { Susquehanna } \\
1\end{array}$ & & 2.79E-01 & $1.70 \mathrm{E}-02$ & $\begin{array}{l}\text { Peach } \\
\text { Bottom } 2\end{array}$ & & $7.98 \mathrm{E}+01$ & $6.10 \mathrm{E}+00$ \\
\hline $\begin{array}{l}\text { Susquehanna } \\
2\end{array}$ & & $2.79 \mathrm{E}-01$ & 1.70E-02 & $\begin{array}{l}\text { Peach } \\
\text { Bottom } 3\end{array}$ & & $7.98 \mathrm{E}+01$ & $6.10 \mathrm{E}+00$ \\
\hline Perry & 2.98E-01 & $1.60 \mathrm{E}+00$ & $1.07 \mathrm{E}+00$ & Monticello & & $1.03 E+02$ & $1.69 \mathrm{E}+01$ \\
\hline $\begin{array}{l}\text { Columbia } \\
\text { Generating }\end{array}$ & & & $3.50 \mathrm{E}+00$ & $\begin{array}{l}\text { Nine Mile } \\
\text { Point } 2\end{array}$ & 2.11E-02 & $1.15 \mathrm{E}+02$ & $6.30 \mathrm{E}+00$ \\
\hline Limerick 2 & $1.62 \mathrm{E}-01$ & $2.08 \mathrm{E}+00$ & $1.67 \mathrm{E}+00$ & Grand Gulf & & $9.07 \mathrm{E}+01$ & $1.07 \mathrm{E}+02$ \\
\hline $\begin{array}{l}\text { Cooper } \\
\text { Station }\end{array}$ & & 3.82E-01 & $5.14 \mathrm{E}+00$ & Fitzpatrick & & $1.00 \mathrm{E}+02$ & $1.07 \mathrm{E}+02$ \\
\hline Quad Cities 1 & & $8.64 \mathrm{E}+00$ & $1.05 \mathrm{E}+00$ & River Bend & & $4.89 \mathrm{E}+01$ & $1.60 \mathrm{E}+02$ \\
\hline Quad Cities 2 & & $8.64 \mathrm{E}+00$ & $1.05 E+00$ & Pilgrim & & $1.98 \mathrm{E}+02$ & $1.08 \mathrm{E}+02$ \\
\hline Duane Arnold & $9.00 \mathrm{E}+00$ & & $3.35 E+00$ & LaSalle 1 & & $3.65 E+02$ & 6.01E-01 \\
\hline $\begin{array}{l}\text { BWR Median } \\
\text { Release }\end{array}$ & & $5.96 \mathrm{E}+00$ & $3.35 E+00$ & LaSalle 2 & & $3.65 E+02$ & 6.01E-01 \\
\hline
\end{tabular}


TABLE 4.2

BWR Gaseous Releases — lodine, 2007

\begin{tabular}{|l|l|}
\multicolumn{1}{|c|}{ BWR Facility } & I-131 (Ci) \\
\hline Susquehanna 1 & $1.16 \mathrm{E}-06$ \\
\hline Susquehanna 2 & $1.16 \mathrm{E}-06$ \\
\hline Columbia Generating & $4.95 \mathrm{E}-06$ \\
\hline Vermont Yankee & $2.71 \mathrm{E}-05$ \\
\hline Limerick 1 & $2.76 \mathrm{E}-05$ \\
\hline Limerick 2 & $2.76 \mathrm{E}-05$ \\
\hline Duane Arnold & $3.46 \mathrm{E}-05$ \\
\hline Clinton & $4.20 \mathrm{E}-05$ \\
\hline Hatch 2 & $7.51 \mathrm{E}-05$ \\
\hline Hatch 1 & $8.09 \mathrm{E}-05$ \\
\hline Cooper Station & $1.77 \mathrm{E}-04$ \\
\hline Browns Ferry 1 & $3.68 \mathrm{E}-04$ \\
\hline Browns Ferry 2 & $3.68 \mathrm{E}-04$ \\
\hline Browns Ferry 3 & $3.68 \mathrm{E}-04$ \\
\hline Perry & $4.73 \mathrm{E}-04$ \\
\hline Nine Mile Point 1 & $4.87 \mathrm{E}-04$ \\
\hline Dresden 2 & $8.15 \mathrm{E}-04$ \\
\hline BWR Median Release & $\mathbf{8 . 1 5 E}-04$ \\
\hline
\end{tabular}

\begin{tabular}{|l|l|}
\multicolumn{1}{|c|}{ BWR Facility } & I-131 (Ci) \\
\hline Dresden 3 & $8.15 \mathrm{E}-04$ \\
\hline Quad Cities 1 & $1.00 \mathrm{E}-03$ \\
\hline Quad Cities 2 & $1.00 \mathrm{E}-03$ \\
\hline Hope Creek & $1.21 \mathrm{E}-03$ \\
\hline Nine Mile Point 2 & $1.68 \mathrm{E}-03$ \\
\hline Oyster Creek & $1.75 \mathrm{E}-03$ \\
\hline Fermi 2 & $2.69 \mathrm{E}-03$ \\
\hline Fitzpatrick & $3.06 \mathrm{E}-03$ \\
\hline Peach Bottom 2 & $4.17 \mathrm{E}-03$ \\
\hline Peach Bottom 3 & $4.17 \mathrm{E}-03$ \\
\hline Monticello & $5.19 \mathrm{E}-03$ \\
\hline Pilgrim & $1.46 \mathrm{E}-02$ \\
\hline River Bend & $1.81 \mathrm{E}-02$ \\
\hline Brunswick 1 & $3.82 \mathrm{E}-02$ \\
\hline Brunswick 2 & $3.82 \mathrm{E}-02$ \\
\hline LaSalle 1 & $4.01 \mathrm{E}-02$ \\
\hline LaSalle 2 & $4.01 \mathrm{E}-02$ \\
\hline Grand Gulf & $4.28 \mathrm{E}-02$ \\
\hline
\end{tabular}


TABLE 4.3

BWR Gaseous Releases — Selected Particulates, 2007

\begin{tabular}{|l|c|c|c|c|}
\multicolumn{1}{|c|}{ BWR Facility } & $\begin{array}{c}\text { Co-58 } \\
\text { (Ci) }\end{array}$ & $\begin{array}{c}\text { Co-60 } \\
\text { (Ci) }\end{array}$ & $\begin{array}{c}\text { Cs-134 } \\
\text { (Ci) }\end{array}$ & $\begin{array}{c}\text { Cs-137 } \\
\text { (Ci) }\end{array}$ \\
\hline Hope Creek & & & & \\
\hline River Bend & & & & \\
\hline Vermont Yankee & & $3.08 \mathrm{E}-07$ & & \\
\hline Hatch 1 & & $3.08 \mathrm{E}-07$ & & \\
\hline Hatch 2 & & $1.16 \mathrm{E}-05$ & & \\
\hline Clinton & $1.83 \mathrm{E}-06$ & $2.76 \mathrm{E}-05$ & & $3.58 \mathrm{E}-07$ \\
\hline Fitzpatrick & & $3.24 \mathrm{E}-05$ & & \\
\hline Limerick 1 & & $3.24 \mathrm{E}-05$ & & \\
\hline Limerick 2 & & & & $3.56 \mathrm{E}-05$ \\
\hline Perry & $9.70 \mathrm{E}-06$ & $3.14 \mathrm{E}-05$ & & \\
\hline Grand Gulf & $1.31 \mathrm{E}-06$ & $5.26 \mathrm{E}-05$ & & $1.28 \mathrm{E}-05$ \\
\hline Peach Bottom 2 & $1.31 \mathrm{E}-06$ & $5.26 \mathrm{E}-05$ & & $1.28 \mathrm{E}-05$ \\
\hline Peach Bottom 3 & $5.50 \mathrm{E}-06$ & $6.68 \mathrm{E}-05$ & $1.65 \mathrm{E}-05$ & $3.37 \mathrm{E}-05$ \\
\hline Pilgrim & $2.30 \mathrm{E}-05$ & $1.23 \mathrm{E}-04$ & & \\
\hline Duane Arnold & $5.51 \mathrm{E}-06$ & $1.49 \mathrm{E}-04$ & $7.75 \mathrm{E}-07$ & $5.84 \mathrm{E}-06$ \\
\hline Brunswick 1 & $5.51 \mathrm{E}-06$ & $1.49 \mathrm{E}-04$ & $7.75 \mathrm{E}-07$ & $5.84 \mathrm{E}-06$ \\
\hline Brunswick 2 & $3.33 \mathrm{E}-06$ & $1.44 \mathrm{E}-04$ & & \\
\hline BWR Median Release & & & & \\
\hline
\end{tabular}


TABLE 4.3 (continued)

BWR Gaseous Releases — Selected Particulates, 2007

\begin{tabular}{|l|c|c|c|c|}
\multicolumn{1}{|c|}{ BWR Facility } & $\begin{array}{c}\text { Co-58 } \\
\text { (Ci) }\end{array}$ & $\begin{array}{c}\text { Co-60 } \\
\text { (Ci) }\end{array}$ & $\begin{array}{c}\text { Cs-134 } \\
\text { (Ci }\end{array}$ & $\begin{array}{c}\text { Cs-137 } \\
\text { (Ci) }\end{array}$ \\
\hline Browns Ferry 1 & $2.28 \mathrm{E}-05$ & $1.44 \mathrm{E}-04$ & & $2.50 \mathrm{E}-05$ \\
\hline Browns Ferry 2 & $2.28 \mathrm{E}-05$ & $1.44 \mathrm{E}-04$ & & $2.50 \mathrm{E}-05$ \\
\hline Browns Ferry 3 & $2.28 \mathrm{E}-05$ & $1.44 \mathrm{E}-04$ & & $2.50 \mathrm{E}-05$ \\
\hline Cooper Station & $2.11 \mathrm{E}-06$ & $1.98 \mathrm{E}-04$ & & $7.33 \mathrm{E}-07$ \\
\hline Nine Mile Point 2 & $9.21 \mathrm{E}-06$ & $1.94 \mathrm{E}-04$ & & \\
\hline Fermi 2 & $6.55 \mathrm{E}-05$ & $1.77 \mathrm{E}-04$ & & \\
\hline Oyster Creek & $5.10 \mathrm{E}-05$ & $2.08 \mathrm{E}-04$ & & \\
\hline Susquehanna 1 & $3.43 \mathrm{E}-06$ & $2.93 \mathrm{E}-04$ & & \\
\hline Susquehanna 2 & $3.43 \mathrm{E}-06$ & $2.93 \mathrm{E}-04$ & & \\
\hline LaSalle 1 & & $3.18 \mathrm{E}-04$ & & $6.55 \mathrm{E}-05$ \\
\hline LaSalle 2 & & $3.18 \mathrm{E}-04$ & & $6.55 \mathrm{E}-05$ \\
\hline Dresden 2 & $8.08 \mathrm{E}-06$ & $3.98 \mathrm{E}-04$ & & \\
\hline Dresden 3 & $8.08 \mathrm{E}-06$ & $3.98 \mathrm{E}-04$ & & \\
\hline Monticello & $3.33 \mathrm{E}-06$ & $2.98 \mathrm{E}-04$ & & $1.34 \mathrm{E}-04$ \\
\hline Quad Cities 1 & & $4.85 \mathrm{E}-04$ & & $1.65 \mathrm{E}-05$ \\
\hline Quad Cities 2 & & $4.85 \mathrm{E}-04$ & & $1.65 \mathrm{E}-05$ \\
\hline Columbia Generating & $5.81 \mathrm{E}-05$ & $5.30 \mathrm{E}-04$ & & \\
\hline Nine Mile Point 1 & $7.09 \mathrm{E}-05$ & $3.77 \mathrm{E}-03$ & $8.39 \mathrm{E}-06$ & $1.66 \mathrm{E}-04$ \\
\hline
\end{tabular}


BWR Gaseous Releases — Tritium, 2007

\begin{tabular}{|l|l|}
\multicolumn{1}{|c|}{ BWR Facility } & H-3 (Ci) \\
\hline Duane Arnold & \\
\hline Perry & \\
\hline Quad Cities 1 & \\
\hline Quad Cities 2 & \\
\hline Limerick 1 & $3.28 \mathrm{E}+00$ \\
\hline Limerick 2 & $3.28 \mathrm{E}+00$ \\
\hline Vermont Yankee & $6.01 \mathrm{E}+00$ \\
\hline Dresden 2 & $1.05 \mathrm{E}+01$ \\
\hline Dresden 3 & $1.05 \mathrm{E}+01$ \\
\hline Browns Ferry 1 & $1.15 \mathrm{E}+01$ \\
\hline Browns Ferry 2 & $1.15 \mathrm{E}+01$ \\
\hline Browns Ferry 3 & $1.15 \mathrm{E}+01$ \\
\hline Fitzpatrick & $1.40 \mathrm{E}+01$ \\
\hline Grand Gulf & $1.56 \mathrm{E}+01$ \\
\hline River Bend & $1.94 \mathrm{E}+01$ \\
\hline Nine Mile Point 1 & $1.97 \mathrm{E}+01$ \\
\hline Cooper Station & $1.98 \mathrm{E}+01$ \\
\hline BWR Median Release & $2.59 \mathrm{E}+01$ \\
\hline
\end{tabular}

\begin{tabular}{|l|l|}
\multicolumn{1}{|c|}{ BWR Facility } & H-3 (Ci) \\
\hline Hope Creek & $2.59 \mathrm{E}+01$ \\
\hline Peach Bottom 2 & $2.66 \mathrm{E}+01$ \\
\hline Peach Bottom 3 & $2.66 \mathrm{E}+01$ \\
\hline Hatch 1 & $3.51 \mathrm{E}+01$ \\
\hline Clinton & $3.75 \mathrm{E}+01$ \\
\hline Monticello & $3.95 \mathrm{E}+01$ \\
\hline Hatch 2 & $4.34 \mathrm{E}+01$ \\
\hline Susquehanna 1 & $4.47 \mathrm{E}+01$ \\
\hline Susquehanna 2 & $4.47 \mathrm{E}+01$ \\
\hline Columbia Generating & $4.48 \mathrm{E}+01$ \\
\hline Oyster Creek & $4.58 \mathrm{E}+01$ \\
\hline LaSalle 1 & $4.76 \mathrm{E}+01$ \\
\hline LaSalle 2 & $4.76 \mathrm{E}+01$ \\
\hline Pilgrim & $5.86 \mathrm{E}+01$ \\
\hline Fermi 2 & $1.25 \mathrm{E}+02$ \\
\hline Brunswick 1 & $1.28 \mathrm{E}+02$ \\
\hline Brunswick 2 & $1.28 \mathrm{E}+02$ \\
\hline Nine Mile Point 2 & $1.38 \mathrm{E}+02$ \\
\hline
\end{tabular}


TABLE 4.5

PWR Gaseous Releases — Selected Fission and Activation Gases, 2007

\begin{tabular}{|l|c|c|c|}
\multicolumn{1}{|c|}{ PWR Facility } & Kr-85 (Ci) & Xe-133 (Ci) & Xe-135 (Ci) \\
\hline Palo Verde 3 & & $2.69 \mathrm{E}-05$ & $4.02 \mathrm{E}-08$ \\
\hline Seabrook & & $1.99 \mathrm{E}-03$ & $4.29 \mathrm{E}-04$ \\
\hline Vogtle 1 & & $1.21 \mathrm{E}-02$ & $2.53 \mathrm{E}-05$ \\
\hline Farley 2 & & $1.81 \mathrm{E}-02$ & $3.40 \mathrm{E}-05$ \\
\hline South Texas 1 & $2.29 \mathrm{E}-02$ & \\
\hline Wolf Creek & & $4.17 \mathrm{E}-03$ & $3.28 \mathrm{E}-02$ \\
\hline Prairie Island 1 & $4.75 \mathrm{E}-02$ & $1.22 \mathrm{E}-03$ & $6.60 \mathrm{E}-04$ \\
\hline Prairie Island 2 & $4.75 \mathrm{E}-02$ & $1.22 \mathrm{E}-03$ & $6.60 \mathrm{E}-04$ \\
\hline Point Beach 1 & & $4.98 \mathrm{E}-02$ & $2.40 \mathrm{E}-03$ \\
\hline Point Beach 2 & & $4.98 \mathrm{E}-02$ & $2.40 \mathrm{E}-03$ \\
\hline Kewaunee & & $7.51 \mathrm{E}-02$ & $2.76 \mathrm{E}-03$ \\
\hline McGuire 1 & $5.08 \mathrm{E}-02$ & $2.67 \mathrm{E}-02$ & $2.61 \mathrm{E}-03$ \\
\hline McGuire 2 & $5.08 \mathrm{E}-02$ & $2.67 \mathrm{E}-02$ & $2.61 \mathrm{E}-03$ \\
\hline Beaver Valley 2 & $2.84 \mathrm{E}-03$ & $9.42 \mathrm{E}-02$ & $4.15 \mathrm{E}-02$ \\
\hline Salem 1 & & $2.15 \mathrm{E}-01$ & $8.18 \mathrm{E}-03$ \\
\hline Byron 2 & $3.77 \mathrm{E}-03$ & $2.14 \mathrm{E}-01$ & $2.17 \mathrm{E}-02$ \\
\hline Palo Verde 1 & $6.39 \mathrm{E}-04$ & $2.40 \mathrm{E}-01$ & $2.02 \mathrm{E}-03$ \\
\hline Beaver Valley 1 & $2.84 \mathrm{E}-03$ & $2.16 \mathrm{E}-01$ & $4.15 \mathrm{E}-02$ \\
\hline Diablo Canyon 1 & $4.55 \mathrm{E}-02$ & $2.50 \mathrm{E}-01$ & $3.09 \mathrm{E}-04$ \\
\hline Diablo Canyon 2 & $4.55 \mathrm{E}-02$ & $2.50 \mathrm{E}-01$ & $3.09 \mathrm{E}-04$ \\
\hline Byron 1 & $3.77 \mathrm{E}-03$ & $3.04 \mathrm{E}-01$ & $1.39 \mathrm{E}-03$ \\
\hline Robinson 2 & $1.67 \mathrm{E}-02$ & $5.83 \mathrm{E}-01$ & $1.96 \mathrm{E}-03$ \\
\hline Salem 2 & & $7.75 \mathrm{E}-01$ & $1.52 \mathrm{E}-04$ \\
\hline Ginna & & $9.12 \mathrm{E}-01$ & $6.37 \mathrm{E}-03$ \\
\hline Catawba 1 & & $8.80 \mathrm{E}-01$ & $6.92 \mathrm{E}-02$ \\
\hline Catawba 2 & $7.00 \mathrm{E}-03$ & $8.80 \mathrm{E}-01$ & $6.92 \mathrm{E}-02$ \\
\hline Surry 1 & $7.00 \mathrm{E}-03$ & $9.33 \mathrm{E}-01$ & $2.76 \mathrm{E}-02$ \\
\hline Surry 2 & & $9.33 \mathrm{E}-01$ & $2.76 \mathrm{E}-02$ \\
\hline Summer & & $4.48 \mathrm{E}-04$ & $1.03 \mathrm{E}+00$ \\
\hline Indian Point 2 & $5.77 \mathrm{E}-01$ & $4.95 \mathrm{E}-01$ & $1.24 \mathrm{E}-01$ \\
\hline Harris & $8.48 \mathrm{E}-03$ & $1.42 \mathrm{E}+00$ & $1.02 \mathrm{E}-01$ \\
\hline Millstone 2 & $1.39 \mathrm{E}+00$ & $3.64 \mathrm{E}-01$ & $2.20 \mathrm{E}-03$ \\
\hline Fort Calhoun & $2.05 \mathrm{E}-03$ & $2.00 \mathrm{E}+00$ & $4.45 \mathrm{E}-02$ \\
\hline St. Lucie 1 & & $2.10 \mathrm{E}+00$ & $9.32 \mathrm{E}-01$ \\
\hline Three Mile Island 1 & $2.91 \mathrm{E}+00$ & $9.99 \mathrm{E}-01$ & $8.04 \mathrm{E}-03$ \\
\hline PWR Median Release & $\mathbf{2 . 6 0 E - 0 2}$ & $1.42 \mathrm{E}+00$ & $\mathbf{2 . 7 6 E - 0 2}$ \\
\hline
\end{tabular}


TABLE 4.5 (continued)

PWR Gaseous Releases — Selected Fission and Activation Gases, 2007

\begin{tabular}{|l|c|c|c|}
\multicolumn{1}{|c|}{ PWR Facility } & Kr-85 (Ci) & $\mathbf{X e - 1 3 3}(\mathbf{C i})$ & $\mathbf{X e - 1 3 5}(\mathbf{C i})$ \\
\hline Cook 1 & $3.31 \mathrm{E}+00$ & $1.03 \mathrm{E}+00$ & $3.71 \mathrm{E}-03$ \\
\hline Cook 2 & $3.31 \mathrm{E}+00$ & $1.03 \mathrm{E}+00$ & $3.71 \mathrm{E}-03$ \\
\hline Crystal River 3 & $1.32 \mathrm{E}+00$ & $2.88 \mathrm{E}+00$ & $2.45 \mathrm{E}-01$ \\
\hline St. Lucie 2 & $1.54 \mathrm{E}-01$ & $4.74 \mathrm{E}+00$ & $3.61 \mathrm{E}-01$ \\
\hline Turkey Point 3 & & $6.03 \mathrm{E}+00$ & $1.70 \mathrm{E}-04$ \\
\hline Turkey Point 4 & & $5.84 \mathrm{E}+00$ & $1.95 \mathrm{E}-01$ \\
\hline Comanche Peak 1 & $1.33 \mathrm{E}+00$ & $4.88 \mathrm{E}+00$ & $8.14 \mathrm{E}-02$ \\
\hline Comanche Peak 2 & $1.33 \mathrm{E}+00$ & $4.88 \mathrm{E}+00$ & $8.14 \mathrm{E}-02$ \\
\hline Arkansas 2 & $4.72 \mathrm{E}-01$ & $6.88 \mathrm{E}+00$ & \\
\hline Indian Point 3 & $8.96 \mathrm{E}-02$ & $7.51 \mathrm{E}+00$ & $2.23 \mathrm{E}-02$ \\
\hline Davis-Besse & $3.41 \mathrm{E}+00$ & $4.20 \mathrm{E}+00$ & $6.23 \mathrm{E}-02$ \\
\hline North Anna 1 & $8.46 \mathrm{E}-01$ & $7.23 \mathrm{E}+00$ & $2.74 \mathrm{E}-01$ \\
\hline North Anna 2 & $8.46 \mathrm{E}-01$ & $7.23 \mathrm{E}+00$ & $2.74 \mathrm{E}-01$ \\
\hline Braidwood 2 & $2.58 \mathrm{E}+00$ & $5.85 \mathrm{E}+00$ & $3.67 \mathrm{E}-02$ \\
\hline Arkansas 1 & $1.06 \mathrm{E}+00$ & $7.51 \mathrm{E}+00$ & \\
\hline Palo Verde 2 & & $8.60 \mathrm{E}+00$ & \\
\hline Braidwood 1 & $2.58 \mathrm{E}+00$ & $6.45 \mathrm{E}+00$ & $3.67 \mathrm{E}-02$ \\
\hline Sequoyah 1 & & $9.03 \mathrm{E}+00$ & $4.80 \mathrm{E}-01$ \\
\hline Sequoyah 2 & & $9.03 \mathrm{E}+00$ & $4.80 \mathrm{E}-01$ \\
\hline Farley 1 & & $7.92 \mathrm{E}+00$ & $3.23 \mathrm{E}+00$ \\
\hline Watts Bar & $4.19 \mathrm{E}-01$ & $1.57 \mathrm{E}+01$ & $7.14 \mathrm{E}-01$ \\
\hline Callaway & $1.44 \mathrm{E}+00$ & $1.70 \mathrm{E}+01$ & $8.71 \mathrm{E}-01$ \\
\hline Waterford 3 & $2.60 \mathrm{E}-02$ & $3.58 \mathrm{E}+01$ & $4.69 \mathrm{E}+00$ \\
\hline South Texas 2 & & $4.40 \mathrm{E}+01$ & \\
\hline Millstone 3 & $1.16 \mathrm{E}+01$ & $3.31 \mathrm{E}+01$ & $7.26 \mathrm{E}-01$ \\
\hline San Onofre 2 & $1.87 \mathrm{E}+00$ & $4.70 \mathrm{E}+01$ & $1.52 \mathrm{E}-03$ \\
\hline San Onofre 3 & $1.87 \mathrm{E}+00$ & $4.70 \mathrm{E}+01$ & $1.52 \mathrm{E}-03$ \\
\hline Vogtle 2 & & $8.49 \mathrm{E}+01$ & $3.14 \mathrm{E}-01$ \\
\hline Oconee 1 & $1.19 \mathrm{E}+00$ & $1.05 \mathrm{E}+02$ & $6.13 \mathrm{E}+00$ \\
\hline Oconee 2 & $1.19 \mathrm{E}+00$ & $1.05 \mathrm{E}+02$ & $6.13 \mathrm{E}+00$ \\
\hline Oconee 3 & $1.19 \mathrm{E}+00$ & $1.05 \mathrm{E}+02$ & $6.13 \mathrm{E}+00$ \\
\hline Calvert Cliffs 1 & $7.16 \mathrm{E}+01$ & $2.28 \mathrm{E}+02$ & $1.32 \mathrm{E}+01$ \\
\hline Calvert Cliffs 2 & $7.16 \mathrm{E}+01$ & $2.28 \mathrm{E}+02$ & $1.32 \mathrm{E}+01$ \\
\hline Palisades & $6.29 \mathrm{E}+00$ & $3.30 \mathrm{E}+02$ & $1.14 \mathrm{E}+00$ \\
\hline
\end{tabular}


TABLE 4.6

PWR Gaseous Releases — lodine, 2007

\begin{tabular}{|l|l|}
\hline \multicolumn{1}{|c|}{ PWR Facility } & I-131 (Ci) \\
\hline Catawba 1 & \\
\hline Catawba 2 & \\
\hline Comanche Peak 1 & \\
\hline Comanche Peak 2 & \\
\hline Diablo Canyon 1 & \\
\hline Diablo Canyon 2 & \\
\hline Fort Calhoun & \\
\hline Ginna & \\
\hline Harris & \\
\hline Indian Point 2 & \\
\hline Kewaunee & \\
\hline Palo Verde 3 & \\
\hline Prairie Island 1 & \\
\hline Prairie Island 2 & \\
\hline Seabrook & \\
\hline South Texas 1 & \\
\hline Summer & \\
\hline Surry 1 & \\
\hline Surry 2 & \\
\hline Vogtle 1 & \\
\hline Wolf Creek & \\
\hline Farley 2 & \\
\hline Beaver Valley 1 & $1.71 \mathrm{E}-06$ \\
\hline Beaver Valley 2 & $1.25 \mathrm{EE}-06$ \\
\hline Vogtle 2 & \\
\hline Salem 2 & \\
\hline McGuire 1 & \\
\hline McGuire 2 & \\
\hline South Texas 2 & \\
\hline Crystal River 3 & \\
\hline Byron 2 & \\
\hline Robinson 2 & \\
\hline Point Beach 1 & \\
\hline Point Beach 2 & \\
\hline Callaway & \\
\hline & \\
\hline
\end{tabular}

\begin{tabular}{|l|l|}
\hline \multicolumn{1}{|c|}{ PWR Facility } & I-131 (Ci) \\
\hline PWR Median Release & $\mathbf{4 . 3 4 E - 0 6}$ \\
\hline Turkey Point 3 & $4.94 \mathrm{E}-06$ \\
\hline Turkey Point 4 & $4.94 \mathrm{E}-06$ \\
\hline Waterford 3 & $5.10 \mathrm{E}-06$ \\
\hline St. Lucie 1 & $8.96 \mathrm{E}-06$ \\
\hline Three Mile Island 1 & $9.22 \mathrm{E}-06$ \\
\hline Farley 1 & $9.31 \mathrm{E}-06$ \\
\hline Salem 1 & $1.30 \mathrm{E}-05$ \\
\hline Davis-Besse & $1.38 \mathrm{E}-05$ \\
\hline Arkansas 1 & $1.98 \mathrm{E}-05$ \\
\hline Byron 1 & $2.48 \mathrm{E}-05$ \\
\hline Braidwood 1 & $2.73 \mathrm{E}-05$ \\
\hline Arkansas 2 & $3.22 \mathrm{E}-05$ \\
\hline Watts Bar & $3.62 \mathrm{E}-05$ \\
\hline Palo Verde 2 & $4.30 \mathrm{E}-05$ \\
\hline Sequoyah 1 & $4.90 \mathrm{E}-05$ \\
\hline Sequoyah 2 & $4.90 \mathrm{E}-05$ \\
\hline Braidwood 2 & $5.54 \mathrm{E}-05$ \\
\hline Cook 1 & $7.34 \mathrm{E}-05$ \\
\hline Cook 2 & $7.34 \mathrm{E}-05$ \\
\hline Millstone 2 & $8.56 \mathrm{E}-05$ \\
\hline Indian Point 3 & $1.42 \mathrm{E}-04$ \\
\hline San Onofre 2 & $1.50 \mathrm{E}-04$ \\
\hline San Onofre 3 & $1.50 \mathrm{E}-04$ \\
\hline Palo Verde 1 & $2.31 \mathrm{E}-04$ \\
\hline North Anna 1 & $4.31 \mathrm{E}-04$ \\
\hline North Anna 2 & $4.31 \mathrm{E}-04$ \\
\hline St. Lucie 2 & $4.51 \mathrm{E}-04$ \\
\hline Oconee 1 & $8.94 \mathrm{E}-04$ \\
\hline Oconee 2 & $8.94 \mathrm{E}-04$ \\
\hline Oconee 3 & $8.94 \mathrm{E}-04$ \\
\hline Millstone 3 & $2.23 \mathrm{E}-03$ \\
\hline Calvert Cliffs 1 & $2.38 \mathrm{E}-03$ \\
\hline Calvert Cliffs 2 & $3.26 \mathrm{E}-02$ \\
\hline Palisades & \\
\hline
\end{tabular}


TABLE 4.7

PWR Gaseous Releases — Selected Particulates, 2007

\begin{tabular}{|l|c|c|c|c|}
\hline \multicolumn{1}{|c|}{ PWR Facility } & $\begin{array}{c}\text { Co-58 } \\
\text { (Ci) }\end{array}$ & $\begin{array}{c}\text { Co-60 } \\
\text { (Ci) }\end{array}$ & $\begin{array}{c}\text { Cs-134 } \\
\text { (Ci) }\end{array}$ & $\begin{array}{c}\text { Cs-137 } \\
\text { (Ci) }\end{array}$ \\
\hline Arkansas 1 & & & & \\
\hline Arkansas 2 & & & & \\
\hline Beaver Valley 2 & & & & \\
\hline Braidwood 1 & & & \\
\hline Braidwood 2 & & & \\
\hline Byron 1 & & & \\
\hline Byron 2 & & & \\
\hline Calvert Cliffs 1 & & & \\
\hline Calvert Cliffs 2 & & & \\
\hline Catawba 1 & & & \\
\hline Catawba 2 & & & \\
\hline Cook 1 & & & \\
\hline Cook 2 & & & \\
\hline Farley 2 & & & \\
\hline Ginna & & & \\
\hline Indian Point 2 & & & \\
\hline Indian Point 3 & & & \\
\hline Kewaunee & & & \\
\hline Palisades & & & & \\
\hline Palo Verde 2 & & & \\
\hline Salem 1 & & & \\
\hline Salem 2 & & & \\
\hline Seabrook & & & \\
\hline Summer & & & \\
\hline Turkey Point 3 & & & \\
\hline Turkey Point 4 & & & \\
\hline Wolf Creek & & & \\
\hline Point Beach 1 & & & \\
\hline Point Beach 2 & & & \\
\hline Farley 1 & & & \\
\hline Vogtle 1 & & & \\
\hline Crystal River 3 & & & \\
\hline Harris & & & \\
\hline Fort Calhoun & & & \\
\hline Millstone 2 & & & \\
\hline PWR Median Release & & & \\
\hline
\end{tabular}


TABLE 4.7 (continued)

PWR Gaseous Releases — Selected Particulates, 2007

\begin{tabular}{|l|c|c|c|c|}
\multicolumn{1}{|c|}{ PWR Facility } & $\begin{array}{c}\text { Co-58 } \\
\text { (Ci) }\end{array}$ & $\begin{array}{c}\text { Co-60 } \\
\text { (Ci) }\end{array}$ & $\begin{array}{c}\text { Cs-134 } \\
\text { (Ci) }\end{array}$ & $\begin{array}{c}\text { Cs-137 } \\
\text { (Ci) }\end{array}$ \\
\hline Comanche Peak 1 & & & $9.56 \mathrm{E}-07$ & \\
\hline Comanche Peak 2 & & & $9.56 \mathrm{E}-07$ & \\
\hline Surry 1 & $1.07 \mathrm{E}-06$ & & & $8.25 \mathrm{E}-09$ \\
\hline Surry 2 & $1.07 \mathrm{E}-06$ & & & $8.25 \mathrm{E}-09$ \\
\hline Diablo Canyon 1 & $1.12 \mathrm{E}-06$ & & & \\
\hline Diablo Canyon 2 & $1.12 \mathrm{E}-06$ & & & \\
\hline South Texas 1 & $6.27 \mathrm{E}-07$ & $1.01 \mathrm{E}-06$ & & \\
\hline Waterford 3 & & & & $2.03 \mathrm{E}-06$ \\
\hline Prairie Island 1 & & & & $2.09 \mathrm{E}-06$ \\
\hline Prairie Island 2 & & & & $2.09 \mathrm{E}-06$ \\
\hline Watts Bar & $5.70 \mathrm{E}-06$ & & & \\
\hline Vogtle 2 & $4.42 \mathrm{E}-06$ & $1.30 \mathrm{E}-06$ & & \\
\hline Robinson 2 & $5.01 \mathrm{E}-06$ & $9.78 \mathrm{E}-07$ & & $4.76 \mathrm{E}-08$ \\
\hline Oconee 1 & $9.59 \mathrm{E}-06$ & $6.47 \mathrm{E}-07$ & & $3.33 \mathrm{E}-07$ \\
\hline Oconee 2 & $9.59 \mathrm{E}-06$ & $6.47 \mathrm{E}-07$ & & $3.33 \mathrm{E}-07$ \\
\hline Oconee 3 & $9.59 \mathrm{E}-06$ & $6.47 \mathrm{E}-07$ & & $3.33 \mathrm{E}-07$ \\
\hline St. Lucie 1 & & $9.25 \mathrm{E}-06$ & & $4.27 \mathrm{E}-06$ \\
\hline Sequoyah 1 & $6.55 \mathrm{E}-06$ & $7.45 \mathrm{E}-06$ & & \\
\hline Sequoyah 2 & $6.55 \mathrm{E}-06$ & $7.45 \mathrm{E}-06$ & & \\
\hline St. Lucie 2 & $4.79 \mathrm{E}-06$ & $2.02 \mathrm{E}-06$ & & $7.20 \mathrm{E}-06$ \\
\hline McGuire 1 & $1.81 \mathrm{E}-05$ & & & \\
\hline McGuire 2 & $1.81 \mathrm{E}-05$ & & & \\
\hline Callaway & $4.62 \mathrm{E}-06$ & $1.36 \mathrm{E}-05$ & & \\
\hline Three Mile Island 1 & & & & $2.53 \mathrm{E}-05$ \\
\hline Davis-Besse & $4.80 \mathrm{E}-05$ & & & \\
\hline Beaver Valley 1 & $1.51 \mathrm{E}-04$ & $2.29 \mathrm{E}-05$ & & $3.06 \mathrm{E}-07$ \\
\hline South Texas 2 & $2.06 \mathrm{E}-04$ & $2.87 \mathrm{E}-05$ & $6.58 \mathrm{E}-08$ & $1.73 \mathrm{E}-07$ \\
\hline Millstone 3 & $2.97 \mathrm{E}-04$ & $4.96 \mathrm{E}-05$ & $1.07 \mathrm{E}-04$ & $5.73 \mathrm{E}-05$ \\
\hline San Onofre 2 & $3.59 \mathrm{E}-04$ & $1.55 \mathrm{E}-04$ & & $6.70 \mathrm{E}-06$ \\
\hline San Onofre 3 & $3.59 \mathrm{E}-04$ & $1.55 \mathrm{E}-04$ & & $6.70 \mathrm{E}-06$ \\
\hline Palo Verde 1 & $5.32 \mathrm{E}-04$ & $9.30 \mathrm{E}-05$ & & $2.30 \mathrm{E}-05$ \\
\hline Palo Verde 3 & $2.16 \mathrm{E}-03$ & $3.89 \mathrm{E}-04$ & & $1.11 \mathrm{E}-05$ \\
\hline North Anna 1 & $1.69 \mathrm{E}-06$ & $1.87 \mathrm{E}-06$ & & $5.16 \mathrm{E}-03$ \\
\hline North Anna 2 & $1.69 \mathrm{E}-06$ & $1.87 \mathrm{E}-06$ & & $5.16 \mathrm{E}-03$ \\
\hline & & & & \\
\hline
\end{tabular}


TABLE 4.8

PWR Gaseous Releases — Tritium, 2007

\begin{tabular}{|l|l|}
\multicolumn{1}{|c|}{ PWR Facility } & H-3 (Ci) \\
\hline Palisades & \\
\hline Calvert Cliffs 1 & $2.98 \mathrm{E}+00$ \\
\hline Calvert Cliffs 2 & $2.98 \mathrm{E}+00$ \\
\hline Summer & $4.39 \mathrm{E}+00$ \\
\hline Fort Calhoun & $4.65 \mathrm{E}+00$ \\
\hline Prairie Island 1 & $5.90 \mathrm{E}+00$ \\
\hline Prairie Island 2 & $5.90 \mathrm{E}+00$ \\
\hline Robinson 2 & $6.68 \mathrm{E}+00$ \\
\hline Turkey Point 4 & $7.70 \mathrm{E}+00$ \\
\hline Millstone 2 & $7.87 \mathrm{E}+00$ \\
\hline Farley 2 & $9.93 \mathrm{E}+00$ \\
\hline Vogtle 2 & $1.00 \mathrm{E}+01$ \\
\hline Turkey Point 3 & $1.05 \mathrm{E}+01$ \\
\hline Crystal River 3 & $1.19 \mathrm{E}+01$ \\
\hline Kewaunee & $1.22 \mathrm{E}+01$ \\
\hline Indian Point 3 & $1.34 \mathrm{E}+01$ \\
\hline Beaver Valley 1 & $1.34 \mathrm{E}+01$ \\
\hline Beaver Valley 2 & $1.34 \mathrm{E}+01$ \\
\hline Indian Point 2 & $1.45 \mathrm{E}+01$ \\
\hline Braidwood 2 & $1.70 \mathrm{E}+01$ \\
\hline Oconee 1 & $1.90 \mathrm{E}+01$ \\
\hline Oconee 2 & $1.90 \mathrm{E}+01$ \\
\hline Oconee 3 & $1.90 \mathrm{E}+01$ \\
\hline Farley 1 & $2.21 \mathrm{E}+01$ \\
\hline Byron 1 & $2.26 \mathrm{E}+01$ \\
\hline Arkansas 1 & $2.60 \mathrm{E}+01$ \\
\hline South Texas 1 & $2.73 \mathrm{E}+01$ \\
\hline Arkansas 2 & $2.74 \mathrm{E}+01$ \\
\hline North Anna 1 & $2.76 \mathrm{E}+01$ \\
\hline North Anna 2 & $2.76 \mathrm{E}+01$ \\
\hline Comanche Peak 1 & $2.79 \mathrm{E}+01$ \\
\hline Comanche Peak 2 & $2.79 \mathrm{E}+01$ \\
\hline Ginna & $2.80 \mathrm{E}+01$ \\
\hline Surry 1 & $3.15 \mathrm{E}+01$ \\
\hline Surry 2 & $3.15 \mathrm{E}+01$ \\
\hline
\end{tabular}

\begin{tabular}{|l|c|}
\multicolumn{1}{|c|}{ PWR Facility } & H-3 $\mathbf{( C i )}$ \\
\hline PWR Median Release & $\mathbf{3 . 1 5 \mathrm { E } + 0 1}$ \\
\hline South Texas 2 & $3.62 \mathrm{E}+01$ \\
\hline Watts Bar & $3.64 \mathrm{E}+01$ \\
\hline Braidwood 1 & $3.64 \mathrm{E}+01$ \\
\hline Callaway & $4.12 \mathrm{E}+01$ \\
\hline San Onofre 2 & $4.21 \mathrm{E}+01$ \\
\hline San Onofre 3 & $4.21 \mathrm{E}+01$ \\
\hline Byron 2 & $4.26 \mathrm{E}+01$ \\
\hline Point Beach 1 & $4.31 \mathrm{E}+01$ \\
\hline Point Beach 2 & $4.31 \mathrm{E}+01$ \\
\hline Wolf Creek & $4.31 \mathrm{E}+01$ \\
\hline Davis-Besse & $5.52 \mathrm{E}+01$ \\
\hline Millstone 3 & $5.52 \mathrm{E}+01$ \\
\hline Vogtle 1 & $6.11 \mathrm{E}+01$ \\
\hline St. Lucie 1 & $6.40 \mathrm{E}+01$ \\
\hline Sequoyah 1 & $6.56 \mathrm{E}+01$ \\
\hline Sequoyah 2 & $6.56 \mathrm{E}+01$ \\
\hline St. Lucie 2 & $7.41 \mathrm{E}+01$ \\
\hline Three Mile Island 1 & $8.52 \mathrm{E}+01$ \\
\hline Catawba 1 & $9.40 \mathrm{E}+01$ \\
\hline Catawba 2 & $9.40 \mathrm{E}+01$ \\
\hline Diablo Canyon 1 & $1.02 \mathrm{E}+02$ \\
\hline Diablo Canyon 2 & $1.02 \mathrm{E}+02$ \\
\hline McGuire 1 & $1.02 \mathrm{E}+02$ \\
\hline McGuire 2 & $1.02 \mathrm{E}+02$ \\
\hline Seabrook & $1.18 \mathrm{E}+02$ \\
\hline Salem 2 & $1.23 \mathrm{E}+02$ \\
\hline Waterford 3 & $1.32 \mathrm{E}+02$ \\
\hline Cook 1 & $1.46 \mathrm{E}+02$ \\
\hline Cook 2 & $1.46 \mathrm{E}+02$ \\
\hline Harris & $2.36 \mathrm{E}+02$ \\
\hline Salem 1 & $2.52 \mathrm{E}+02$ \\
\hline Palo Verde 2 & $5.78 \mathrm{E}+02$ \\
\hline Palo Verde 1 & $5.96 \mathrm{E}+02$ \\
\hline Palo Verde 3 & $7.60 \mathrm{E}+02$ \\
\hline & \\
\hline
\end{tabular}


TABLE 4.9

BWR Liquid Releases - Selected Fission and Activation Products, 2007

\begin{tabular}{|c|c|c|c|c|c|c|}
\hline BWR Facility & $\begin{array}{c}\text { Co-58 } \\
\text { (Ci) }\end{array}$ & $\begin{array}{c}\text { Co-60 } \\
\text { (Ci) }\end{array}$ & $\begin{array}{c}\text { Cs-134 } \\
\text { (Ci) }\end{array}$ & $\begin{array}{c}\text { Cs-137 } \\
\text { (Ci) }\end{array}$ & $\begin{array}{c}\mathrm{Fe}-55 \\
\text { (Ci) }\end{array}$ & $\begin{array}{l}\text { I-131 } \\
\text { (Ci) }\end{array}$ \\
\hline \multicolumn{7}{|l|}{ Clinton } \\
\hline \multicolumn{7}{|l|}{ Columbia Generating } \\
\hline \multicolumn{7}{|l|}{ Cooper Station } \\
\hline \multicolumn{7}{|l|}{ Duane Arnold } \\
\hline \multicolumn{7}{|l|}{ Fermi 2} \\
\hline \multicolumn{7}{|l|}{ LaSalle 1} \\
\hline \multicolumn{7}{|l|}{ LaSalle 2} \\
\hline \multicolumn{7}{|l|}{ Nine Mile Point 1} \\
\hline \multicolumn{7}{|l|}{ Nine Mile Point 2} \\
\hline \multicolumn{7}{|l|}{ Oyster Creek } \\
\hline \multicolumn{7}{|l|}{ Vermont Yankee } \\
\hline Monticello & 2.12E-08 & $8.42 \mathrm{E}-08$ & & $1.60 \mathrm{E}-08$ & & \\
\hline Fitzpatrick & & & & & 1.17E-05 & \\
\hline Pilgrim & & 1.75E-05 & 1.64E-05 & 8.92E-05 & & \\
\hline Susquehanna 1 & $9.39 \mathrm{E}-06$ & 1.47E-04 & & $3.81 \mathrm{E}-07$ & & \\
\hline Susquehanna 2 & $9.39 E-06$ & $1.47 \mathrm{E}-04$ & & 3.81E-07 & & \\
\hline Hatch 2 & $3.98 \mathrm{E}-06$ & 2.83E-04 & & 4.03E-05 & 1.43E-04 & \\
\hline BWR Median Release & 9.39E-06 & 1.79E-04 & & 6.65E-06 & & \\
\hline Quad Cities 1 & $1.26 \mathrm{E}-05$ & 1.79E-04 & & $6.50 \mathrm{E}-05$ & $6.40 \mathrm{E}-04$ & \\
\hline Quad Cities 2 & $1.26 \mathrm{E}-05$ & 1.79E-04 & & $6.50 \mathrm{E}-05$ & $6.40 \mathrm{E}-04$ & \\
\hline Limerick 1 & 7.32E-05 & 1.77E-03 & $4.36 \mathrm{E}-06$ & 1.90E-04 & & $1.09 \mathrm{E}-06$ \\
\hline Limerick 2 & $7.32 \mathrm{E}-05$ & $1.77 \mathrm{E}-03$ & $4.36 \mathrm{E}-06$ & $1.90 \mathrm{E}-04$ & & $1.09 \mathrm{E}-06$ \\
\hline Perry & $3.76 \mathrm{E}-05$ & $1.87 \mathrm{E}-03$ & & $3.41 \mathrm{E}-04$ & & \\
\hline Brunswick 1 & $3.51 \mathrm{E}-05$ & $9.90 \mathrm{E}-04$ & $1.90 \mathrm{E}-05$ & 1.36E-04 & 4.56E-04 & $6.88 \mathrm{E}-04$ \\
\hline Brunswick 2 & $3.51 \mathrm{E}-05$ & $9.90 \mathrm{E}-04$ & $1.90 \mathrm{E}-05$ & 1.36E-04 & 4.56E-04 & $6.88 \mathrm{E}-04$ \\
\hline River Bend & $1.68 \mathrm{E}-05$ & 2.43E-03 & & & $2.10 \mathrm{E}-03$ & \\
\hline Hatch 1 & $3.01 \mathrm{E}-06$ & $1.82 \mathrm{E}-03$ & & $8.28 \mathrm{E}-04$ & 2.33E-03 & \\
\hline Dresden 2 & $3.00 \mathrm{E}-05$ & $2.80 \mathrm{E}-04$ & & $6.65 \mathrm{E}-06$ & $1.79 \mathrm{E}-02$ & \\
\hline Dresden 3 & $3.00 \mathrm{E}-05$ & $2.80 \mathrm{E}-04$ & & $6.65 \mathrm{E}-06$ & 1.79E-02 & \\
\hline Browns Ferry 1 & 3.19E-05 & $3.51 \mathrm{E}-03$ & $2.82 \mathrm{E}-03$ & $1.22 \mathrm{E}-02$ & $1.92 \mathrm{E}-05$ & $1.38 \mathrm{E}-04$ \\
\hline Browns Ferry 2 & 3.19E-05 & $3.51 \mathrm{E}-03$ & $2.82 \mathrm{E}-03$ & $1.22 \mathrm{E}-02$ & $1.92 \mathrm{E}-05$ & $1.38 \mathrm{E}-04$ \\
\hline Browns Ferry 3 & 3.19E-05 & $3.51 \mathrm{E}-03$ & $2.82 \mathrm{E}-03$ & $1.22 \mathrm{E}-02$ & $1.92 \mathrm{E}-05$ & $1.38 \mathrm{E}-04$ \\
\hline Hope Creek & $9.82 \mathrm{E}-04$ & 4.33E-03 & $3.08 \mathrm{E}-04$ & $4.28 \mathrm{E}-04$ & $2.86 \mathrm{E}-02$ & $1.67 \mathrm{E}-05$ \\
\hline Grand Gulf & $6.48 \mathrm{E}-03$ & $2.25 \mathrm{E}-02$ & & 8.70E-05 & 7.47E-02 & 4.55E-04 \\
\hline Peach Bottom 2 & 1.40E-02 & $1.66 \mathrm{E}-01$ & & 1.29E-03 & $1.82 \mathrm{E}-02$ & $5.50 \mathrm{E}-06$ \\
\hline Peach Bottom 3 & 1.40E-02 & $1.66 \mathrm{E}-01$ & & 1.29E-03 & 1.82E-02 & $5.50 \mathrm{E}-06$ \\
\hline
\end{tabular}


TABLE 4.10

BWR Liquid Releases — Tritium, 2007

\begin{tabular}{|l|l|}
\hline \multicolumn{1}{|c|}{ BWR Facility } & H-3 (Ci) \\
\hline Clinton & \\
\hline Columbia Generating & \\
\hline Cooper Station & \\
\hline Duane Arnold & \\
\hline Fermi 2 & \\
\hline LaSalle 1 & \\
\hline LaSalle 2 & \\
\hline Nine Mile Point 1 & \\
\hline Nine Mile Point 2 & \\
\hline Oyster Creek & \\
\hline Vermont Yankee & \\
\hline Monticello & $2.27 \mathrm{E}-05$ \\
\hline Fitzpatrick & $1.26 \mathrm{E}-01$ \\
\hline Pilgrim & $2.25 \mathrm{E}-01$ \\
\hline Quad Cities 1 & $5.30 \mathrm{E}-01$ \\
\hline Quad Cities 2 & $5.30 \mathrm{E}-01$ \\
\hline Peach Bottom 2 & $2.02 \mathrm{E}+00$ \\
\hline BWR Median Release & $\mathbf{2 . 0 2 E + 0 0}$ \\
\hline
\end{tabular}

\begin{tabular}{|l|l|}
\hline \multicolumn{1}{|c|}{ BWR Facility } & H-3 (Ci) \\
\hline Peach Bottom 3 & $2.02 \mathrm{E}+00$ \\
\hline Hope Creek & $9.53 \mathrm{E}+00$ \\
\hline Browns Ferry 1 & $1.05 \mathrm{E}+01$ \\
\hline Browns Ferry 2 & $1.05 \mathrm{E}+01$ \\
\hline Browns Ferry 3 & $1.05 \mathrm{E}+01$ \\
\hline Hatch 2 & $2.20 \mathrm{E}+01$ \\
\hline Hatch 1 & $2.35 \mathrm{E}+01$ \\
\hline Limerick 1 & $2.36 \mathrm{E}+01$ \\
\hline Limerick 2 & $2.36 \mathrm{E}+01$ \\
\hline Susquehanna 1 & $3.52 \mathrm{E}+01$ \\
\hline Susquehanna 2 & $3.52 \mathrm{E}+01$ \\
\hline Perry & $4.64 \mathrm{E}+01$ \\
\hline Dresden 2 & $7.96 \mathrm{E}+01$ \\
\hline Dresden 3 & $7.96 \mathrm{E}+01$ \\
\hline Grand Gulf & $1.04 \mathrm{E}+02$ \\
\hline River Bend & $1.31 \mathrm{E}+02$ \\
\hline Brunswick 1 & $1.31 \mathrm{E}+02$ \\
\hline Brunswick 2 & $1.31 \mathrm{E}+02$ \\
\hline
\end{tabular}


TABLE 4.11

PWR Liquid Releases — Selected Fission and Activation Products, 2007

\begin{tabular}{|c|c|c|c|c|c|c|}
\hline PWR Facility & $\begin{array}{c}\text { Co-58 } \\
\text { (Ci) }\end{array}$ & $\begin{array}{c}\text { Co-60 } \\
\text { (Ci) }\end{array}$ & $\begin{array}{c}\text { Cs-134 } \\
\text { (Ci) }\end{array}$ & $\begin{array}{c}\text { Cs-137 } \\
\text { (Ci) }\end{array}$ & $\begin{array}{c}\mathrm{Fe}-55 \\
\text { (Ci) }\end{array}$ & $\begin{array}{c}I-131 \\
\text { (Ci) }\end{array}$ \\
\hline \multicolumn{7}{|l|}{ Palo Verde 1} \\
\hline \multicolumn{7}{|l|}{ Palo Verde 2} \\
\hline \multicolumn{7}{|l|}{ Palo Verde 3} \\
\hline Braidwood 1 & 4.45E-04 & 3.27E-04 & $2.90 \mathrm{E}-05$ & $1.93 \mathrm{E}-05$ & & $6.94 \mathrm{E}-06$ \\
\hline Braidwood 2 & 4.45E-04 & 3.27E-04 & $2.90 \mathrm{E}-05$ & $1.93 \mathrm{E}-05$ & & $6.94 \mathrm{E}-06$ \\
\hline Ginna & 8.39E-04 & 1.77E-04 & & & & \\
\hline Comanche Peak 1 & $5.24 \mathrm{E}-04$ & 2.91E-04 & & & 2.64E-04 & \\
\hline Comanche Peak 2 & $5.24 \mathrm{E}-04$ & 2.91E-04 & & & 2.64E-04 & \\
\hline Cook 1 & $6.46 \mathrm{E}-04$ & $3.61 \mathrm{E}-04$ & $4.62 \mathrm{E}-05$ & $5.64 \mathrm{E}-05$ & 2.60E-04 & $1.20 \mathrm{E}-06$ \\
\hline Cook 2 & $6.46 \mathrm{E}-04$ & $3.61 \mathrm{E}-04$ & 4.62E-05 & $5.64 \mathrm{E}-05$ & 2.60E-04 & $1.20 \mathrm{E}-06$ \\
\hline Salem 2 & $1.26 \mathrm{E}-03$ & 5.53E-04 & 7.89E-06 & 2.64E-04 & & \\
\hline Three Mile Island 1 & $2.71 \mathrm{E}-05$ & & & 1.65E-03 & $8.44 \mathrm{E}-04$ & \\
\hline Fort Calhoun & $9.21 \mathrm{E}-04$ & $8.44 \mathrm{E}-04$ & $5.89 \mathrm{E}-05$ & 5.27E-04 & & $6.22 \mathrm{E}-04$ \\
\hline Wolf Creek & $2.88 \mathrm{E}-03$ & $3.09 \mathrm{E}-04$ & & $7.98 \mathrm{E}-05$ & & $3.26 \mathrm{E}-05$ \\
\hline Oconee 1 & $5.27 \mathrm{E}-03$ & $1.39 \mathrm{E}-05$ & & $1.18 \mathrm{E}-04$ & & $6.73 \mathrm{E}-05$ \\
\hline Oconee 2 & $5.27 \mathrm{E}-03$ & 1.39E-05 & & $1.18 \mathrm{E}-04$ & & $6.73 \mathrm{E}-05$ \\
\hline Oconee 3 & $5.27 \mathrm{E}-03$ & 1.39E-05 & & $1.18 \mathrm{E}-04$ & & $6.73 \mathrm{E}-05$ \\
\hline Calvert Cliffs 1 & $9.40 \mathrm{E}-04$ & $3.01 \mathrm{E}-04$ & $1.53 \mathrm{E}-04$ & 1.79E-04 & $3.65 \mathrm{E}-03$ & 2.53E-04 \\
\hline Calvert Cliffs 2 & $9.40 \mathrm{E}-04$ & $3.01 \mathrm{E}-04$ & $1.53 \mathrm{E}-04$ & $1.79 \mathrm{E}-04$ & $3.65 \mathrm{E}-03$ & 2.53E-04 \\
\hline Indian Point 3 & $2.21 \mathrm{E}-03$ & 2.49E-03 & $5.22 \mathrm{E}-05$ & $1.37 \mathrm{E}-04$ & 1.17E-03 & 4.72E-05 \\
\hline South Texas 1 & $9.06 \mathrm{E}-04$ & 4.02E-03 & 2.79E-05 & $2.23 \mathrm{E}-04$ & 1.69E-03 & \\
\hline South Texas 2 & $1.32 \mathrm{E}-03$ & 4.08E-03 & 4.36E-06 & $9.87 \mathrm{E}-05$ & $1.59 \mathrm{E}-03$ & \\
\hline Salem 1 & $4.18 \mathrm{E}-03$ & 1.86E-03 & $7.25 \mathrm{E}-05$ & 1.76E-03 & & \\
\hline Crystal River 3 & $6.15 \mathrm{E}-04$ & 7.04E-03 & 1.67E-06 & $1.41 \mathrm{E}-04$ & $8.86 \mathrm{E}-05$ & $1.06 \mathrm{E}-06$ \\
\hline Byron 1 & 7.04E-03 & $1.30 \mathrm{E}-03$ & & & & \\
\hline Byron 2 & $7.04 \mathrm{E}-03$ & $1.30 \mathrm{E}-03$ & & & & \\
\hline Point Beach 1 & $3.13 \mathrm{E}-03$ & $2.72 \mathrm{E}-03$ & & $5.25 \mathrm{E}-05$ & $3.11 \mathrm{E}-03$ & $1.87 \mathrm{E}-05$ \\
\hline Point Beach 2 & $3.13 \mathrm{E}-03$ & 2.72E-03 & & $5.25 \mathrm{E}-05$ & 3.11E-03 & $1.87 \mathrm{E}-05$ \\
\hline Millstone 2 & $7.32 \mathrm{E}-04$ & $1.90 \mathrm{E}-03$ & $9.80 \mathrm{E}-04$ & 1.76E-03 & 4.09E-03 & $2.08 \mathrm{E}-06$ \\
\hline Vogtle 2 & 2.97E-03 & $2.15 \mathrm{E}-03$ & $5.95 \mathrm{E}-06$ & $8.53 \mathrm{E}-05$ & 4.66E-03 & \\
\hline Robinson 2 & $2.36 \mathrm{E}-03$ & 2.26E-03 & & 6.16E-05 & $5.38 \mathrm{E}-03$ & \\
\hline Surry 1 & $5.42 \mathrm{E}-03$ & $3.51 \mathrm{E}-03$ & & $1.57 \mathrm{E}-03$ & & 3.74E-06 \\
\hline Surry 2 & $5.42 \mathrm{E}-03$ & $3.51 \mathrm{E}-03$ & & $1.57 \mathrm{E}-03$ & & 3.74E-06 \\
\hline Davis-Besse & 3.71E-04 & 1.13E-04 & 1.93E-04 & $7.39 \mathrm{E}-04$ & $1.02 \mathrm{E}-02$ & \\
\hline Callaway & $4.08 \mathrm{E}-03$ & $1.64 \mathrm{E}-03$ & 2.03E-03 & $3.97 \mathrm{E}-03$ & & \\
\hline PWR Median Release & $3.68 \mathrm{E}-03$ & $2.22 \mathrm{E}-03$ & $5.95 \mathrm{E}-06$ & 1.25E-04 & $2.88 \mathrm{E}-03$ & 6.87E-07 \\
\hline
\end{tabular}


TABLE 4.11 (continued)

PWR Liquid Releases — Selected Fission and Activation Products, 2007

\begin{tabular}{|c|c|c|c|c|c|c|}
\hline PWR Facility & $\begin{array}{c}\text { Co-58 } \\
\text { (Ci) }\end{array}$ & $\begin{array}{c}\text { Co-60 } \\
\text { (Ci) }\end{array}$ & $\begin{array}{c}\text { Cs-134 } \\
\text { (Ci) }\end{array}$ & $\begin{array}{c}\text { Cs-137 } \\
\text { (Ci) }\end{array}$ & $\begin{array}{c}\text { Fe-55 } \\
\text { (Ci) }\end{array}$ & $\begin{array}{c}\mathrm{I}-131 \\
\text { (Ci) }\end{array}$ \\
\hline McGuire 1 & $4.96 \mathrm{E}-03$ & $1.65 \mathrm{E}-03$ & $1.17 \mathrm{E}-03$ & $4.04 \mathrm{E}-03$ & & $1.02 \mathrm{E}-06$ \\
\hline McGuire 2 & $96 \mathrm{E}-03$ & $1.65 \mathrm{E}-03$ & $1.17 \mathrm{E}-03$ & $4.04 \mathrm{E}-03$ & & $02 \mathrm{E}-06$ \\
\hline Summer & $94 \mathrm{E}-03$ & $.23 \mathrm{E}-03$ & $1.21 \mathrm{E}-03$ & $1.43 \mathrm{E}-03$ & $5.61 \mathrm{E}-03$ & 1.07E-05 \\
\hline Catawba 1 & 77E-03 & $.31 \mathrm{E}-03$ & $4.02 \mathrm{E}-07$ & $8.56 \mathrm{E}-05$ & & \\
\hline Catawba 2 & 77E-03 & $5.31 \mathrm{E}-03$ & 4.02E-07 & $8.56 \mathrm{E}-05$ & & \\
\hline Indian Point 2 & 29E-03 & $1.45 \mathrm{E}-03$ & $5.56 \mathrm{E}-04$ & $1.06 \mathrm{E}-02$ & & \\
\hline Diablo Canyon 1 & $6.11 \mathrm{E}-03$ & $3.61 \mathrm{E}-03$ & & 1.03E-07 & $5.18 \mathrm{E}-03$ & $9.15 \mathrm{E}-06$ \\
\hline Diablo Canyon 2 & $11 \mathrm{E}-03$ & $3.61 \mathrm{E}-03$ & & & $5.18 \mathrm{E}-03$ & $9.15 \mathrm{E}-06$ \\
\hline Prairie Island 1 & $3.14 \mathrm{E}-03$ & $1.38 \mathrm{E}-03$ & & 7.0 & 1.14E-02 & \\
\hline Prairie Island 2 & $14 \mathrm{E}-$ & $1.38 \mathrm{E}-03$ & & & 1.14E-02 & \\
\hline St. Lucie 1 & $7.68 \mathrm{E}-03$ & $3.31 \mathrm{E}-03$ & $5.81 \mathrm{E}-06$ & 1.25 & $6.33 \mathrm{E}-03$ & $1.51 \mathrm{E}-05$ \\
\hline St. Lucie 2 & $7.68 \mathrm{E}-03$ & $3.31 \mathrm{E}-03$ & 5.81 & 1.25 & $6.33 \mathrm{E}-03$ & $1.51 \mathrm{E}-05$ \\
\hline San Onofre 2 & $65 \mathrm{E}$ & $3.65 \mathrm{E}-03$ & & & $8.10 \mathrm{E}-03$ & \\
\hline San Onofre 3 & $65 \mathrm{E}-03$ & $3.65 \mathrm{E}-03$ & & & 8.10E-03 & \\
\hline Seabrook & $15 \mathrm{E}-03$ & $1.90 \mathrm{E}-03$ & & & 1.66E-02 & \\
\hline Kewal & 51E-03 & 4.97E-03 & & & 1.40E-02 & \\
\hline Arkan & $37 \mathrm{E}-03$ & $2.22 \mathrm{E}-03$ & & & 1.67E-02 & \\
\hline Turke & & $1.65 \mathrm{E}-03$ & & & $6.96 \mathrm{E}-03$ & \\
\hline Turkey Point 4 & $35 \mathrm{E}-02$ & $1.65 \mathrm{E}-03$ & $3.34 \mathrm{E}-06$ & & $6.96 \mathrm{E}-03$ & \\
\hline Harris & 46E-02 & 4.95E-03 & & & $2.88 \mathrm{E}-03$ & \\
\hline Vogt & & $6.17 \mathrm{E}-03$ & & & 1.54E-02 & \\
\hline Farley & & $1.02 \mathrm{E}-02$ & E-06 & -04 & $3.04 \mathrm{E}-03$ & \\
\hline Palis & 1.60 & $1.22 \mathrm{E}-02$ & & & & \\
\hline Farley & 2 & 1.17E-02 & & & $\mathrm{E}-03$ & $=-07$ \\
\hline Mills & 3 & $9.85 \mathrm{E}-03$ & $8.7 \mathrm{~s}$ & & 1.95E-02 & $1.20 \mathrm{E}-03$ \\
\hline Arkansas 1 & $2.84 \mathrm{E}-02$ & $2.26 \mathrm{E}-03$ & 1.38 & 6.0 & 3.47E-04 & $6.10 \mathrm{E}-04$ \\
\hline Beaver Valley 1 & $1.57 \mathrm{E}-02$ & $7.53 \mathrm{E}-03$ & 1.19 & 1.0 & 1.83E-02 & \\
\hline Beaver Valley 2 & $1.57 \mathrm{E}-02$ & $7.53 \mathrm{E}-03$ & 1.19 & & $1.83 \mathrm{E}-02$ & \\
\hline Sequoyah 1 & $2.59 \mathrm{E}-02$ & 1.15E-02 & $1.32 \mathrm{E}-03$ & 2.56 & $9.77 \mathrm{E}-03$ & 2.87E-04 \\
\hline Sequoyah 2 & $2.59 \mathrm{E}-02$ & 1.15E-02 & $1.32 \mathrm{E}-03$ & & $9.77 \mathrm{E}-03$ & 2.87E-04 \\
\hline North Anna 1 & $1.35 \mathrm{E}-02$ & 3.77E-02 & 1.99E-03 & 7.67E-03 & $1.04 \mathrm{E}-02$ & 1.87E-04 \\
\hline North Anna 2 & $1.35 \mathrm{E}-02$ & $3.77 \mathrm{E}-02$ & & & $1.04 \mathrm{E}-02$ & 1.87E-04 \\
\hline Watts Bar & $1.22 \mathrm{E}-02$ & $1.46 \mathrm{E}-02$ & $5.33 \mathrm{E}-03$ & & $4.51 \mathrm{E}-02$ & $5.38 \mathrm{E}-04$ \\
\hline Waterford 3 & 1.13E-01 & $6.25 \mathrm{E}-03$ & $1.72 \mathrm{E}-04$ & 3.85E-06 & 3.86E-02 & 1.33E-04 \\
\hline
\end{tabular}


TABLE 4.12

PWR Liquid Releases — Tritium, 2007

\begin{tabular}{|l|l|}
\hline \multicolumn{1}{|c|}{ PWR Facility } & H-3 (Ci) \\
\hline Palo Verde 1 & \\
\hline Palo Verde 2 & \\
\hline Palo Verde 3 & \\
\hline Millstone 2 & $1.49 \mathrm{E}+02$ \\
\hline Fort Calhoun & $1.65 \mathrm{E}+02$ \\
\hline Summer & $1.69 \mathrm{E}+02$ \\
\hline Kewaunee & $2.39 \mathrm{E}+02$ \\
\hline Comanche Peak 1 & $2.66 \mathrm{E}+02$ \\
\hline Comanche Peak 2 & $2.66 \mathrm{E}+02$ \\
\hline Vogtle 2 & $2.69 \mathrm{E}+02$ \\
\hline Point Beach 1 & $2.94 \mathrm{E}+02$ \\
\hline Point Beach 2 & $2.94 \mathrm{E}+02$ \\
\hline Oconee 1 & $3.04 \mathrm{E}+02$ \\
\hline Oconee 2 & $3.04 \mathrm{E}+02$ \\
\hline Oconee 3 & $3.04 \mathrm{E}+02$ \\
\hline Robinson 2 & $3.58 \mathrm{E}+02$ \\
\hline Prairie Island 1 & $3.60 \mathrm{E}+02$ \\
\hline Prairie Island 2 & $3.60 \mathrm{E}+02$ \\
\hline Arkansas 2 & $4.02 \mathrm{E}+02$ \\
\hline St. Lucie 1 & $4.11 \mathrm{E}+02$ \\
\hline St. Lucie 2 & $4.11 \mathrm{E}+02$ \\
\hline Calvert Cliffs 1 & $4.14 \mathrm{E}+02$ \\
\hline Calvert Cliffs 2 & $4.14 \mathrm{E}+02$ \\
\hline Ginna & $4.14 \mathrm{E}+02$ \\
\hline Braidwood 1 & $4.43 \mathrm{E}+02$ \\
\hline Braidwood 2 & $4.43 \mathrm{E}+02$ \\
\hline Arkansas 1 & $4.56 \mathrm{E}+02$ \\
\hline Salem 2 & $4.60 \mathrm{E}+02$ \\
\hline Seabrook & $4.81 \mathrm{E}+02$ \\
\hline Vogtle 1 & $4.87 \mathrm{E}+02$ \\
\hline Turkey Point 3 & $5.04 \mathrm{E}+02$ \\
\hline Turkey Point 4 & $5.04 \mathrm{E}+02$ \\
\hline Davis-Besse & $5.18 \mathrm{E}+02$ \\
\hline Farley 2 & $5.46 \mathrm{E}+02$ \\
\hline Beaver Valley 1 & $5.51 \mathrm{E}+02$ \\
\hline
\end{tabular}

\begin{tabular}{|l|c|}
\hline \multicolumn{1}{|c|}{ PWR Facility } & H-3 (Ci) \\
\hline PWR Median Release & $\mathbf{5 . 5 1 E + 0 2}$ \\
\hline Beaver Valley 2 & $5.51 \mathrm{E}+02$ \\
\hline Three Mile Island 1 & $5.67 \mathrm{E}+02$ \\
\hline North Anna 1 & $5.82 \mathrm{E}+02$ \\
\hline North Anna 2 & $5.82 \mathrm{E}+02$ \\
\hline Surry 1 & $5.89 \mathrm{E}+02$ \\
\hline Surry 2 & $5.89 \mathrm{E}+02$ \\
\hline Waterford 3 & $5.94 \mathrm{E}+02$ \\
\hline Farley 1 & $5.99 \mathrm{E}+02$ \\
\hline Watts Bar & $6.05 \mathrm{E}+02$ \\
\hline Harris & $6.65 \mathrm{E}+02$ \\
\hline Catawba 1 & $6.94 \mathrm{E}+02$ \\
\hline Catawba 2 & $6.94 \mathrm{E}+02$ \\
\hline Indian Point 2 & $6.94 \mathrm{E}+02$ \\
\hline South Texas 1 & $7.08 \mathrm{E}+02$ \\
\hline Crystal River 3 & $7.13 \mathrm{E}+02$ \\
\hline South Texas 2 & $7.19 \mathrm{E}+02$ \\
\hline Callaway & $7.71 \mathrm{E}+02$ \\
\hline Indian Point 3 & $7.74 \mathrm{E}+02$ \\
\hline Salem 1 & $7.75 \mathrm{E}+02$ \\
\hline McGuire 1 & $8.17 \mathrm{E}+02$ \\
\hline McGuire 2 & $8.17 \mathrm{E}+02$ \\
\hline Wolf Creek & $8.23 \mathrm{E}+02$ \\
\hline Palisades & $8.39 \mathrm{E}+02$ \\
\hline San Onofre 2 & $9.08 \mathrm{E}+02$ \\
\hline San Onofre 3 & $9.08 \mathrm{E}+02$ \\
\hline Sequoyah 1 & $9.36 \mathrm{E}+02$ \\
\hline Sequoyah 2 & $9.36 \mathrm{E}+02$ \\
\hline Millstone 3 & $1.04 \mathrm{E}+03$ \\
\hline Byron 1 & $1.37 \mathrm{E}+03$ \\
\hline Byron 2 & $1.37 \mathrm{E}+03$ \\
\hline Diablo Canyon 1 & $1.60 \mathrm{E}+03$ \\
\hline Diablo Canyon 2 & $1.60 \mathrm{E}+03$ \\
\hline Cook 1 & $1.77 \mathrm{E}+03$ \\
\hline Cook 2 +03 \\
\hline
\end{tabular}




\section{FIGURE 4.1 \\ BWR Gaseous Releases - Selected Fission and Activation Gases}

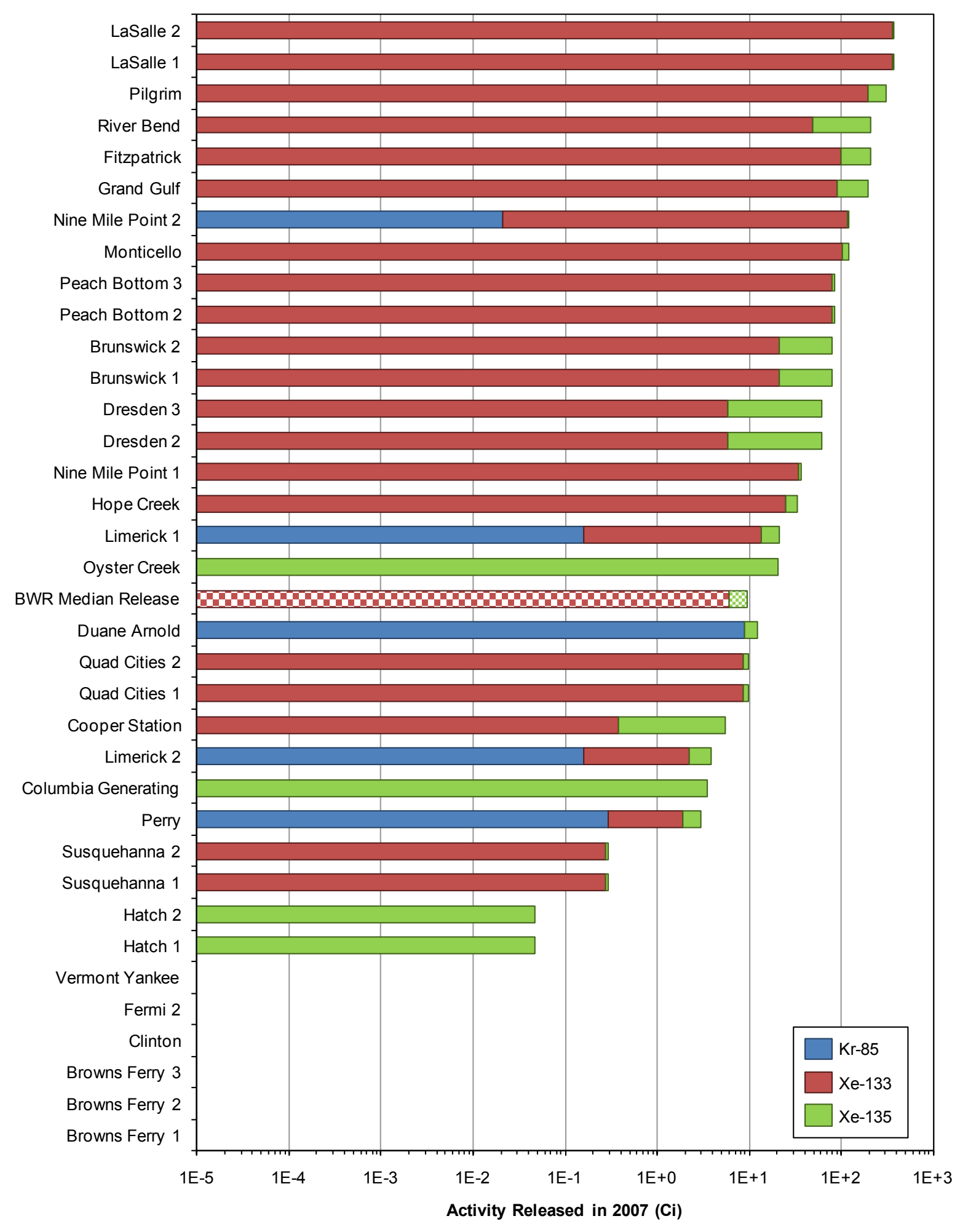


FIGURE 4.2

BWR Gaseous Releases — lodine

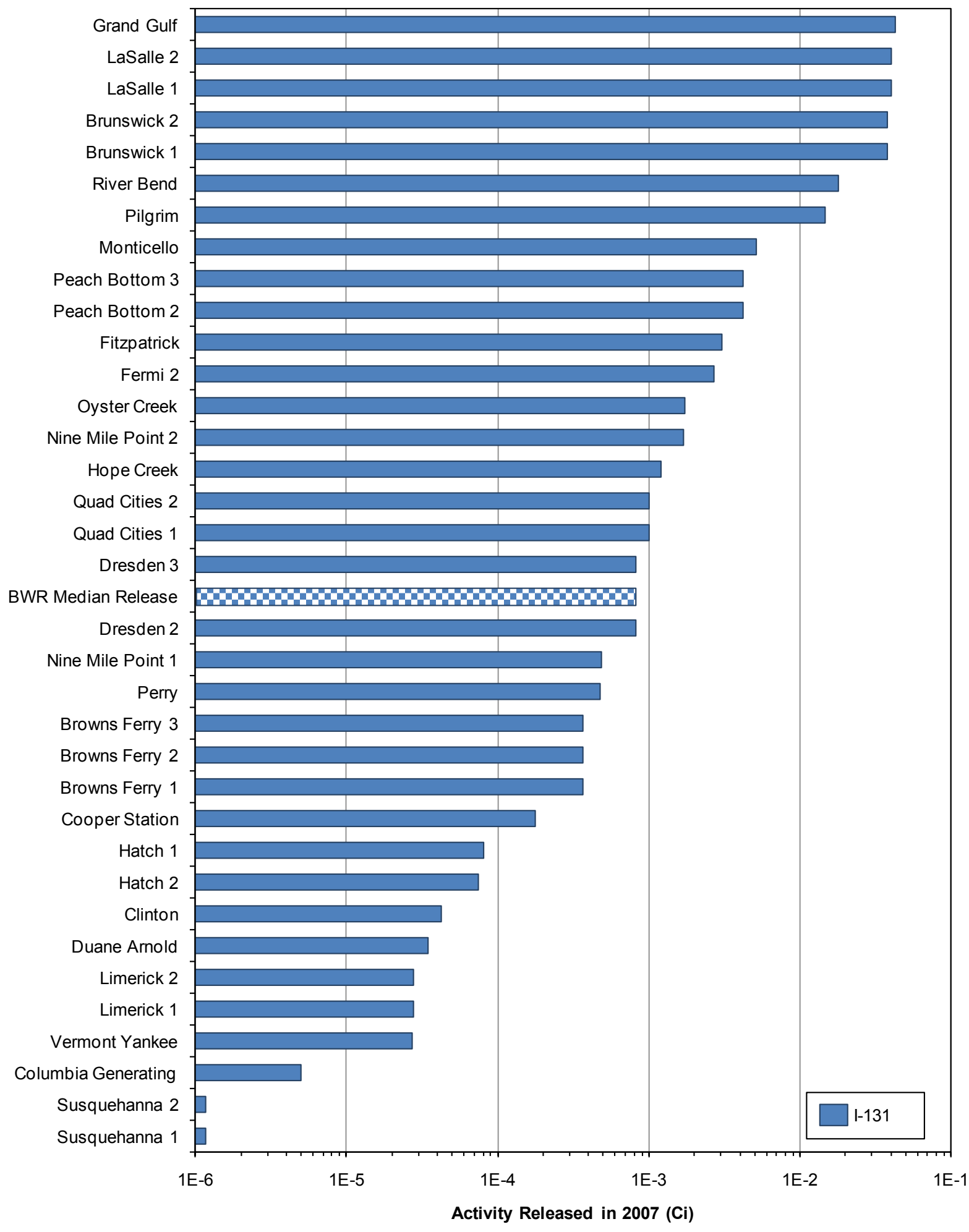




\section{FIGURE 4.3 \\ BWR Gaseous Releases - Selected Particulates}

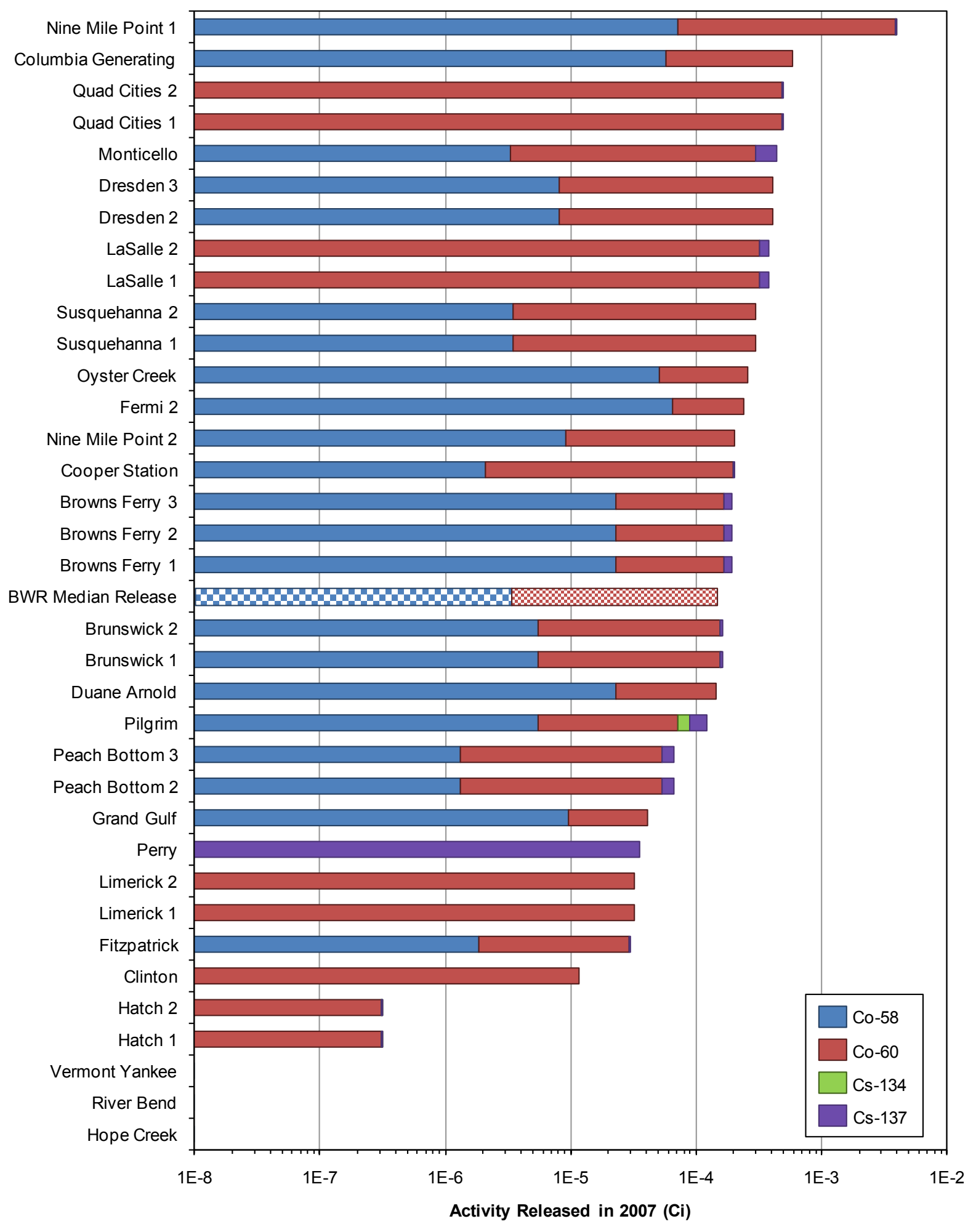


FIGURE 4.4

BWR Gaseous Releases - Tritium

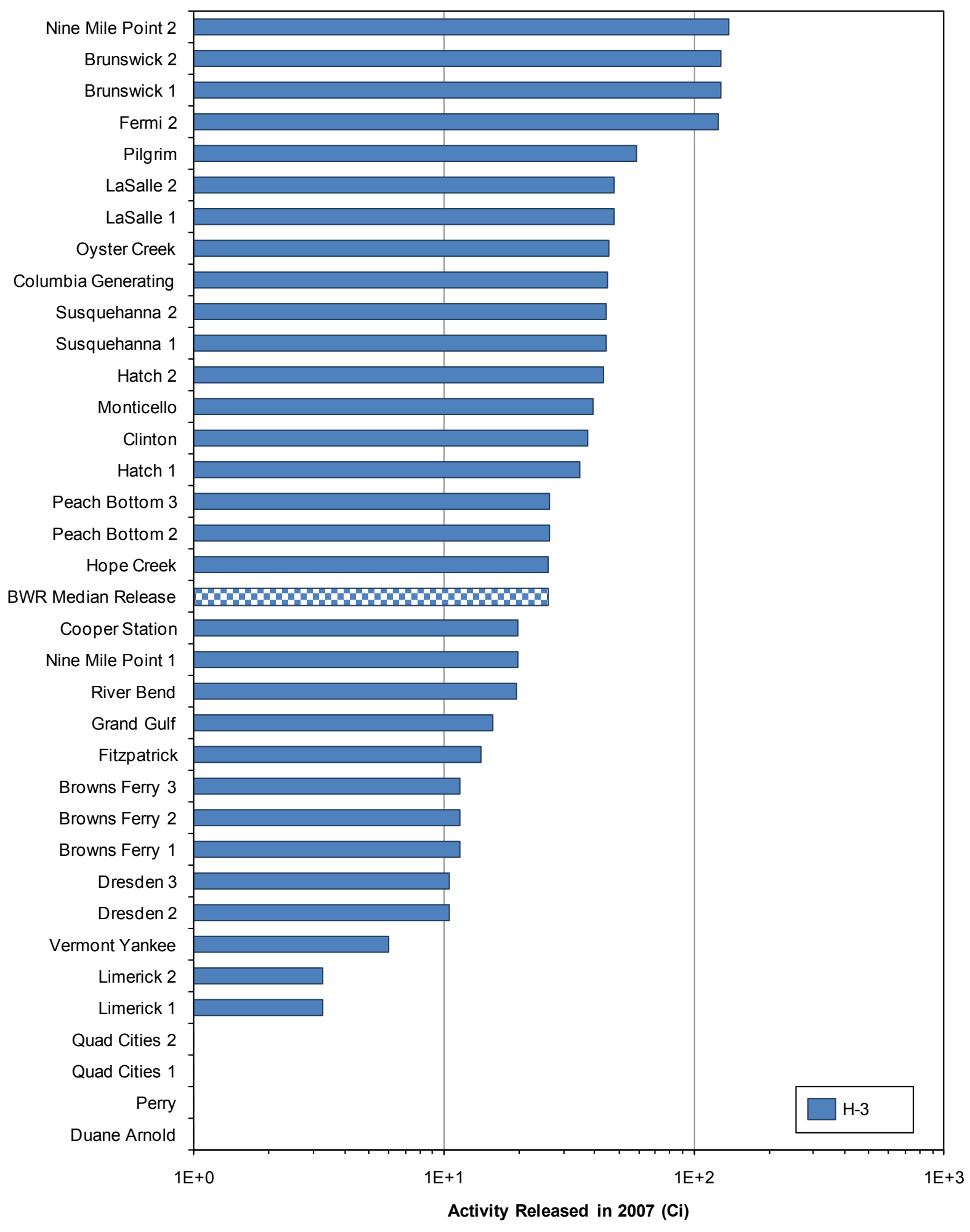




\section{FIGURE 4.5 \\ PWR Gaseous Releases - Selected Fission and Activation Gases}

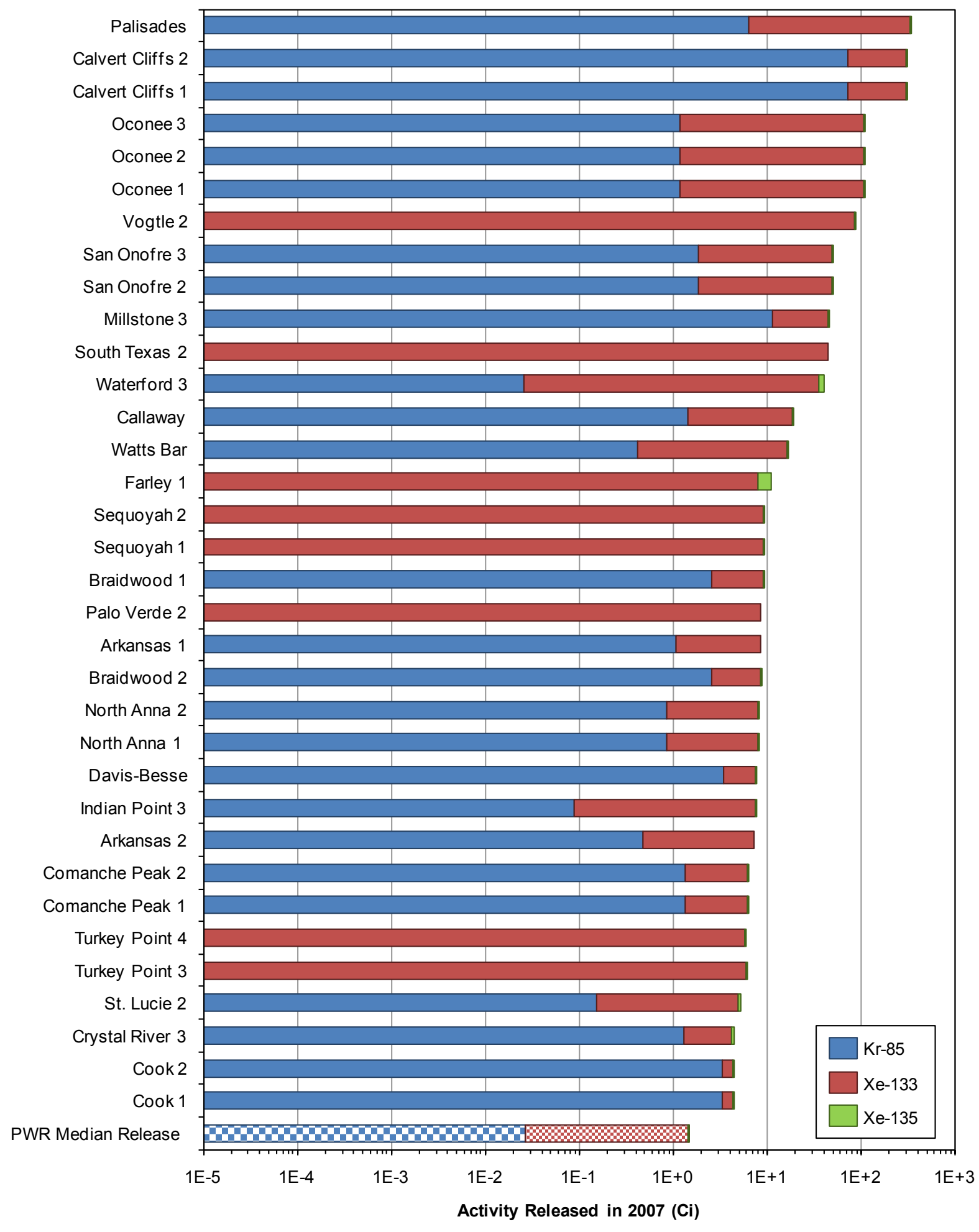


FIGURE 4.5 (continued) PWR Gaseous Releases - Selected Fission and Activation Gases

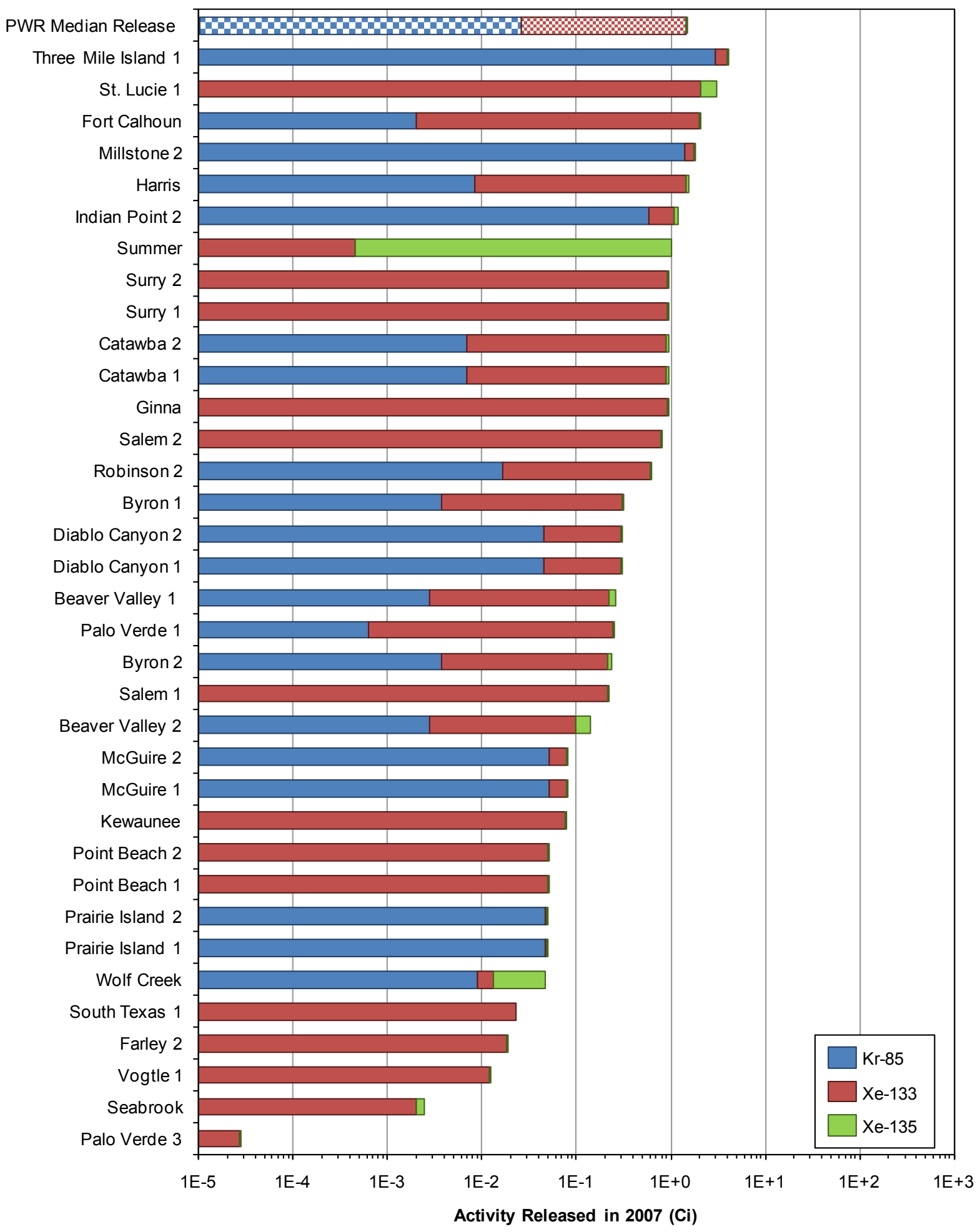


FIGURE 4.6

PWR Gaseous Releases — lodine

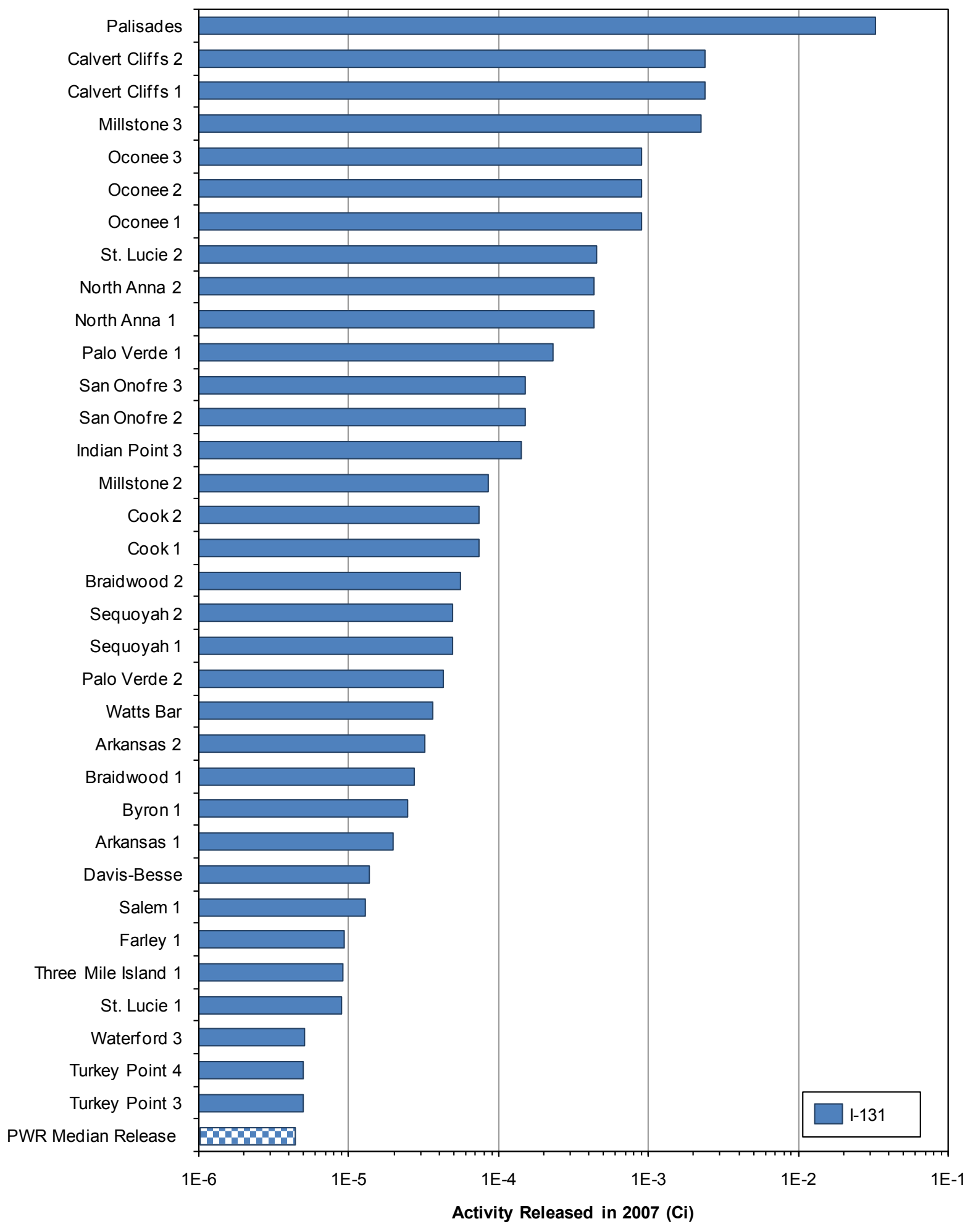


FIGURE 4.6 (continued)

PWR Gaseous Releases — lodine

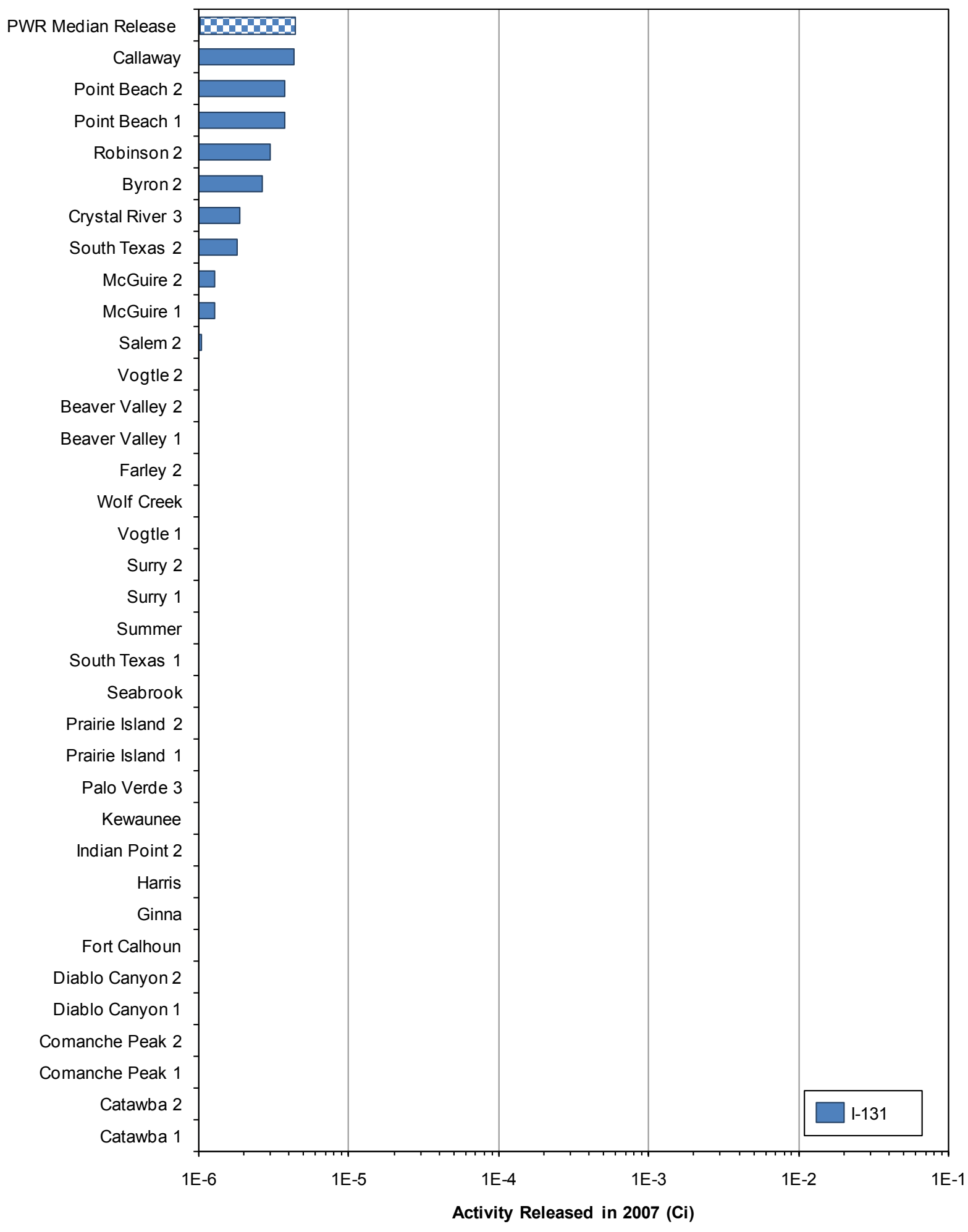


FIGURE 4.7

PWR Gaseous Releases — Selected Particulates

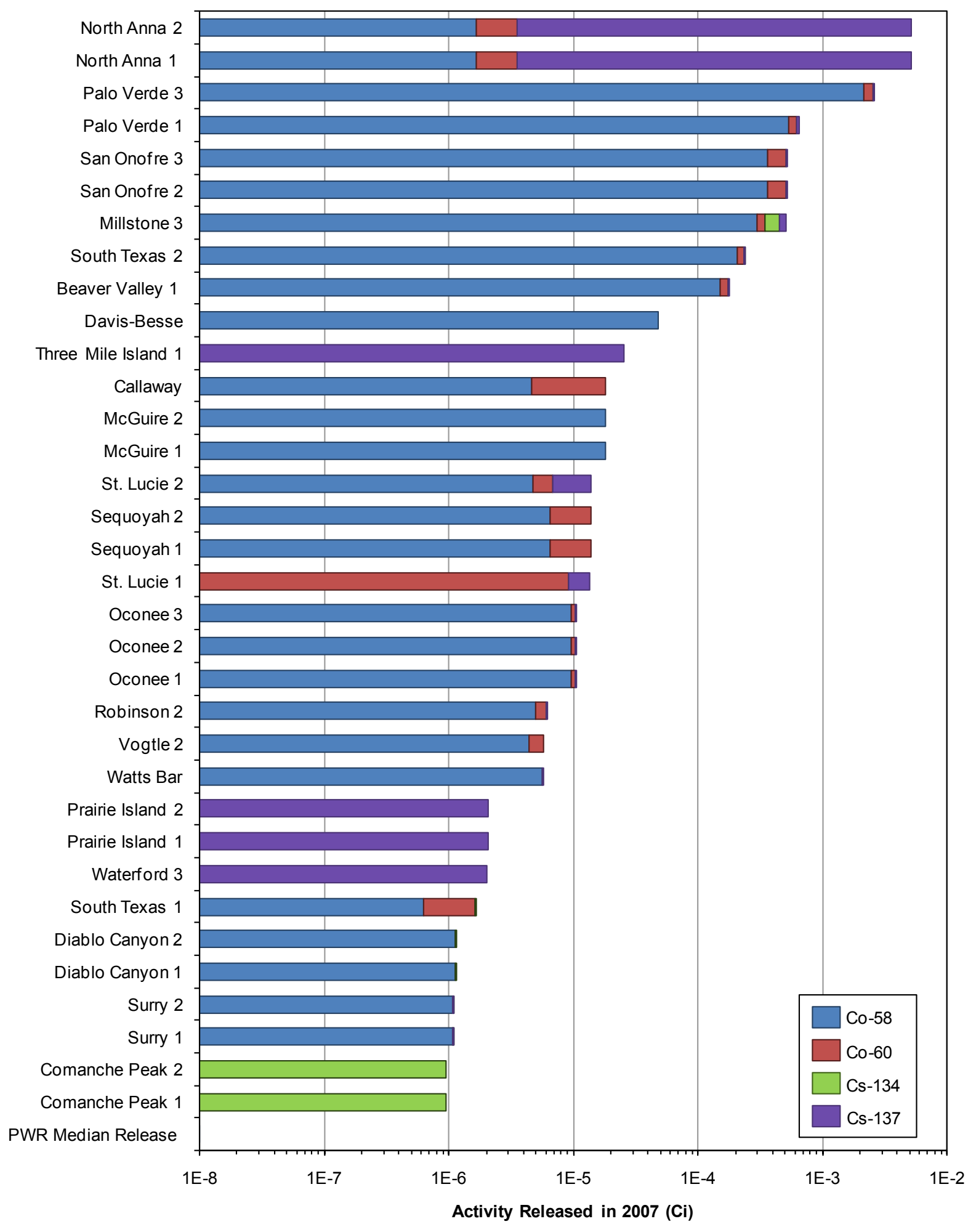


FIGURE 4.7 (continued)

PWR Gaseous Releases - Selected Particulates

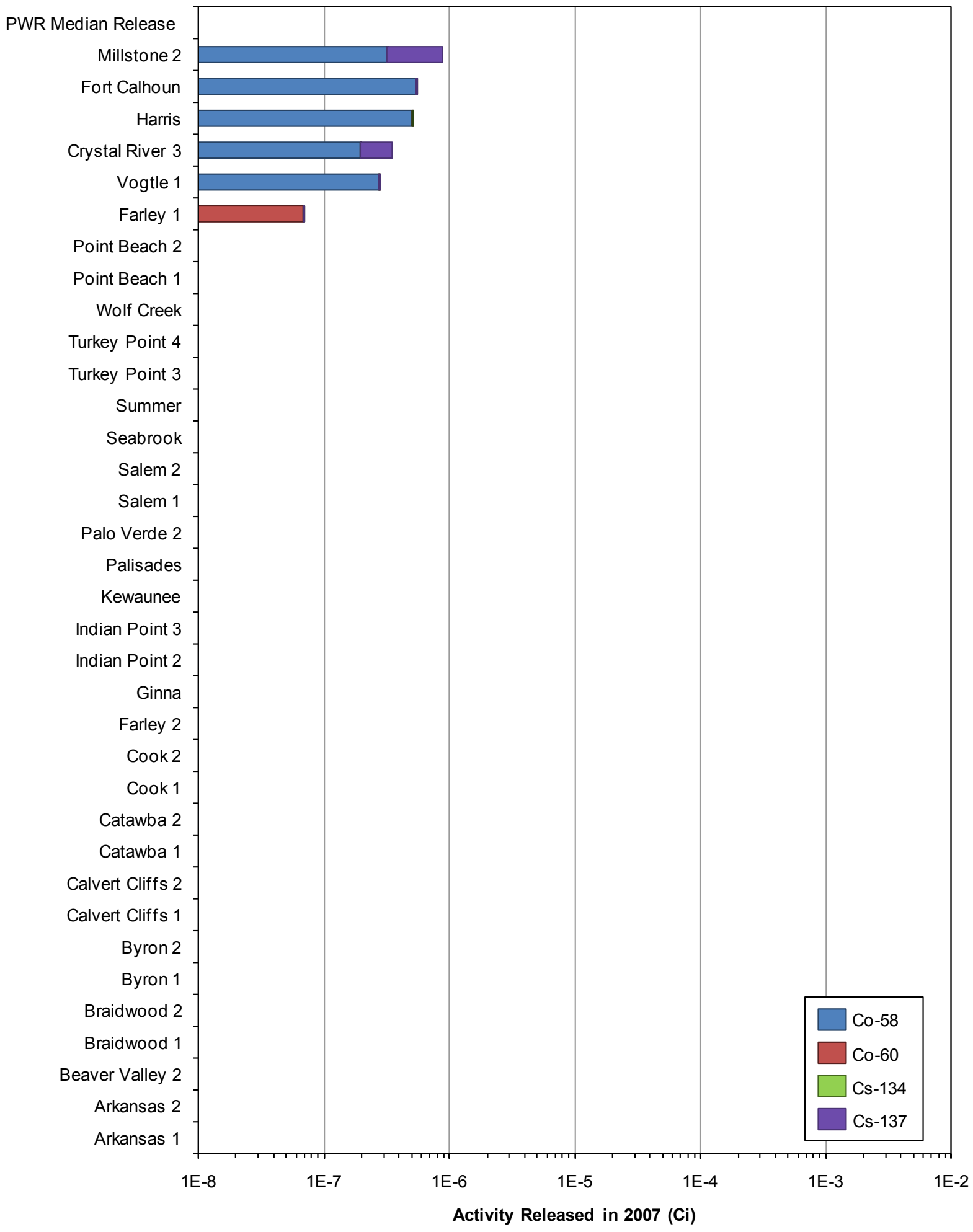


FIGURE 4.8

PWR Gaseous Releases - Tritium

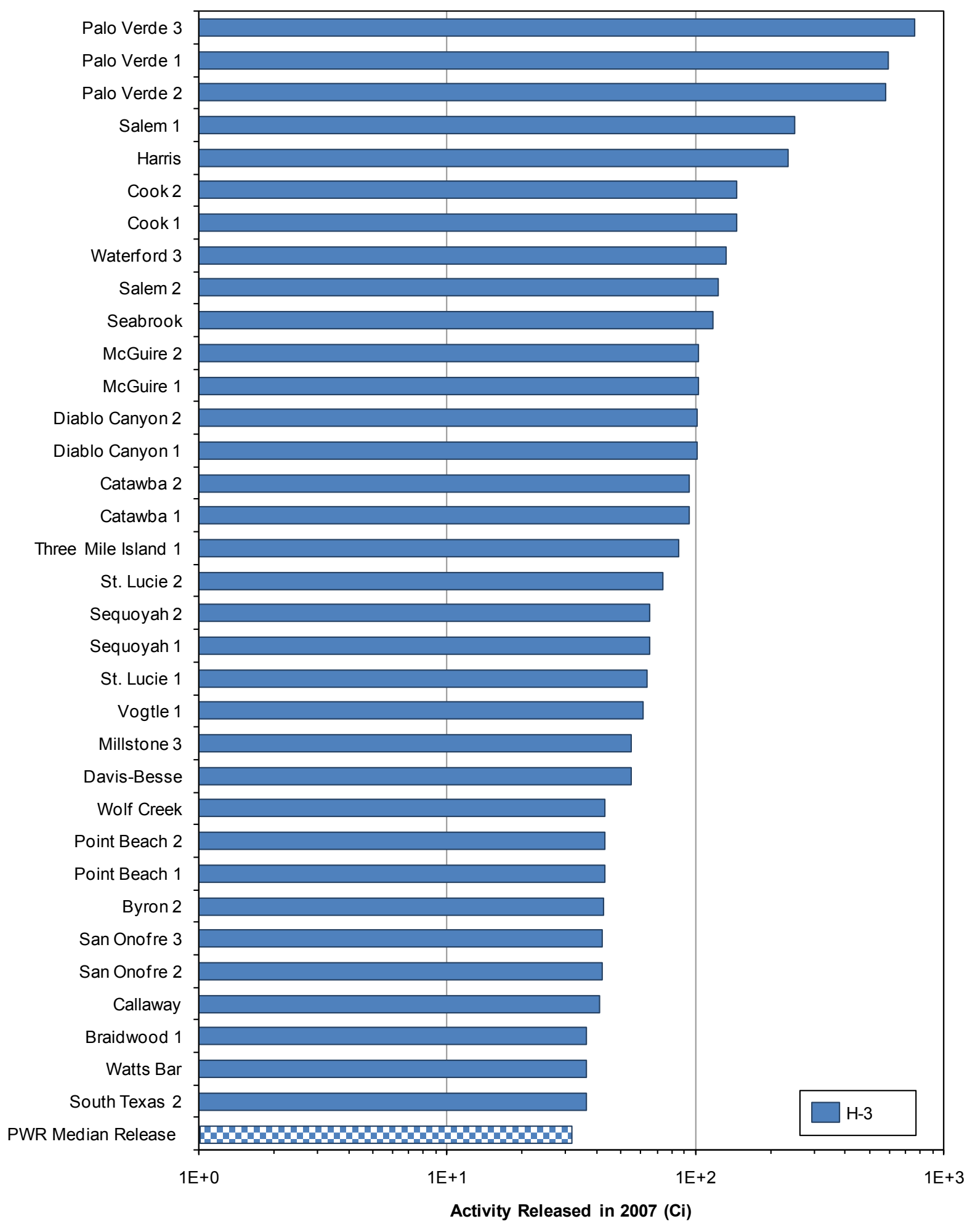


FIGURE 4.8 (continued)

PWR Gaseous Releases - Tritium

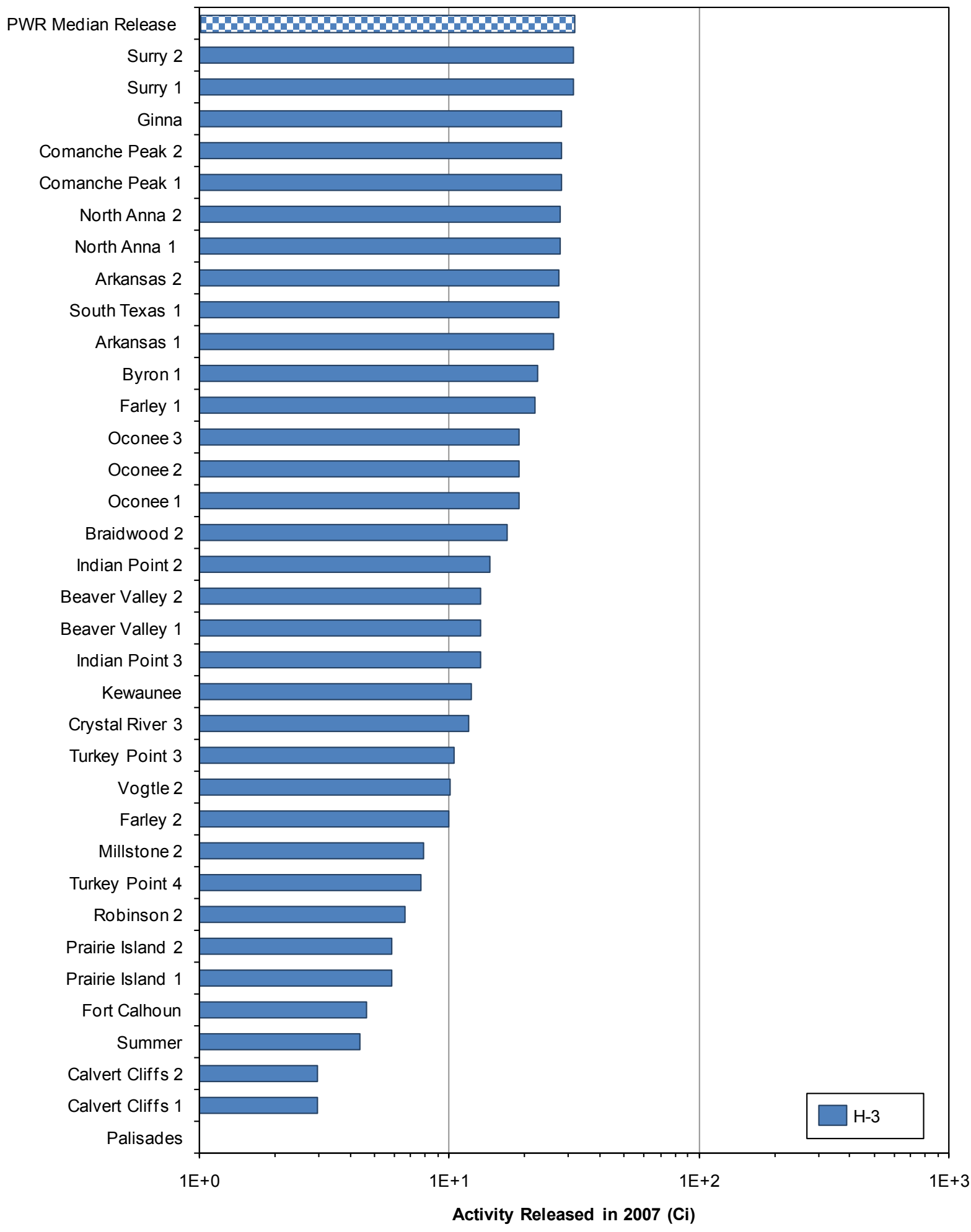


FIGURE 4.9

BWR Liquid Releases - Selected Fission and Activation Products

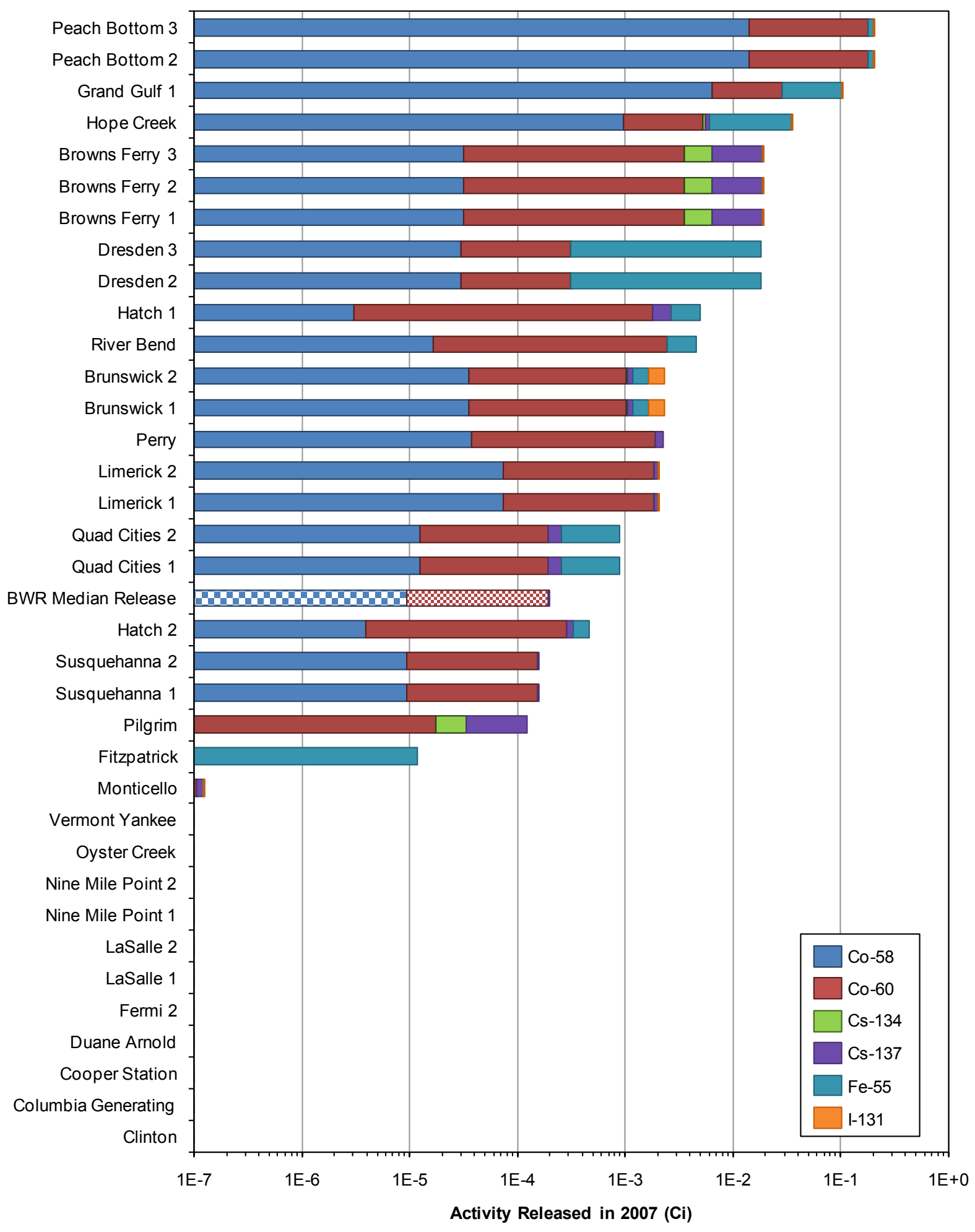


FIGURE 4.10

BWR Liquid Releases - Tritium

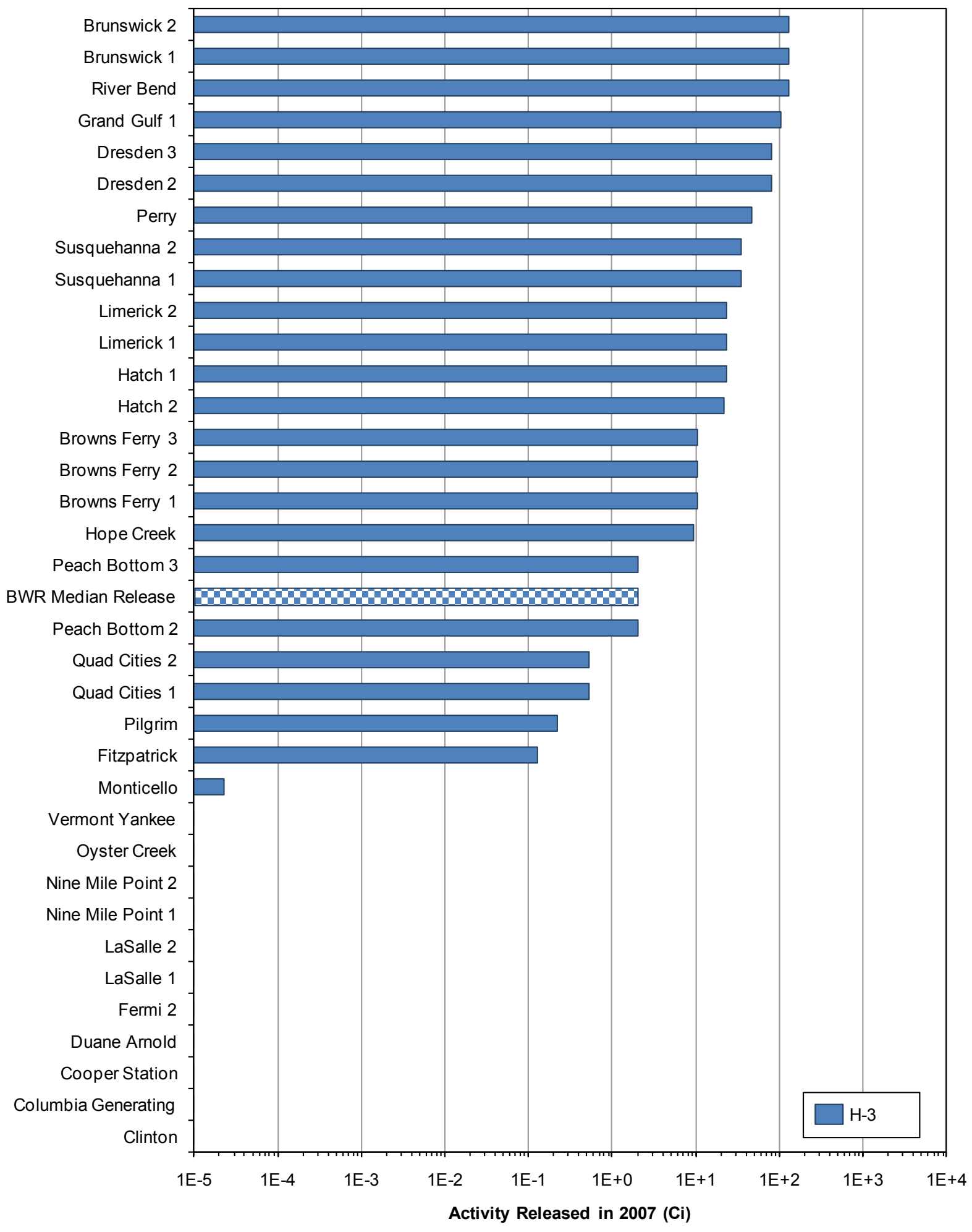


FIGURE 4.11

PWR Liquid Releases - Selected Fission and Activation Products

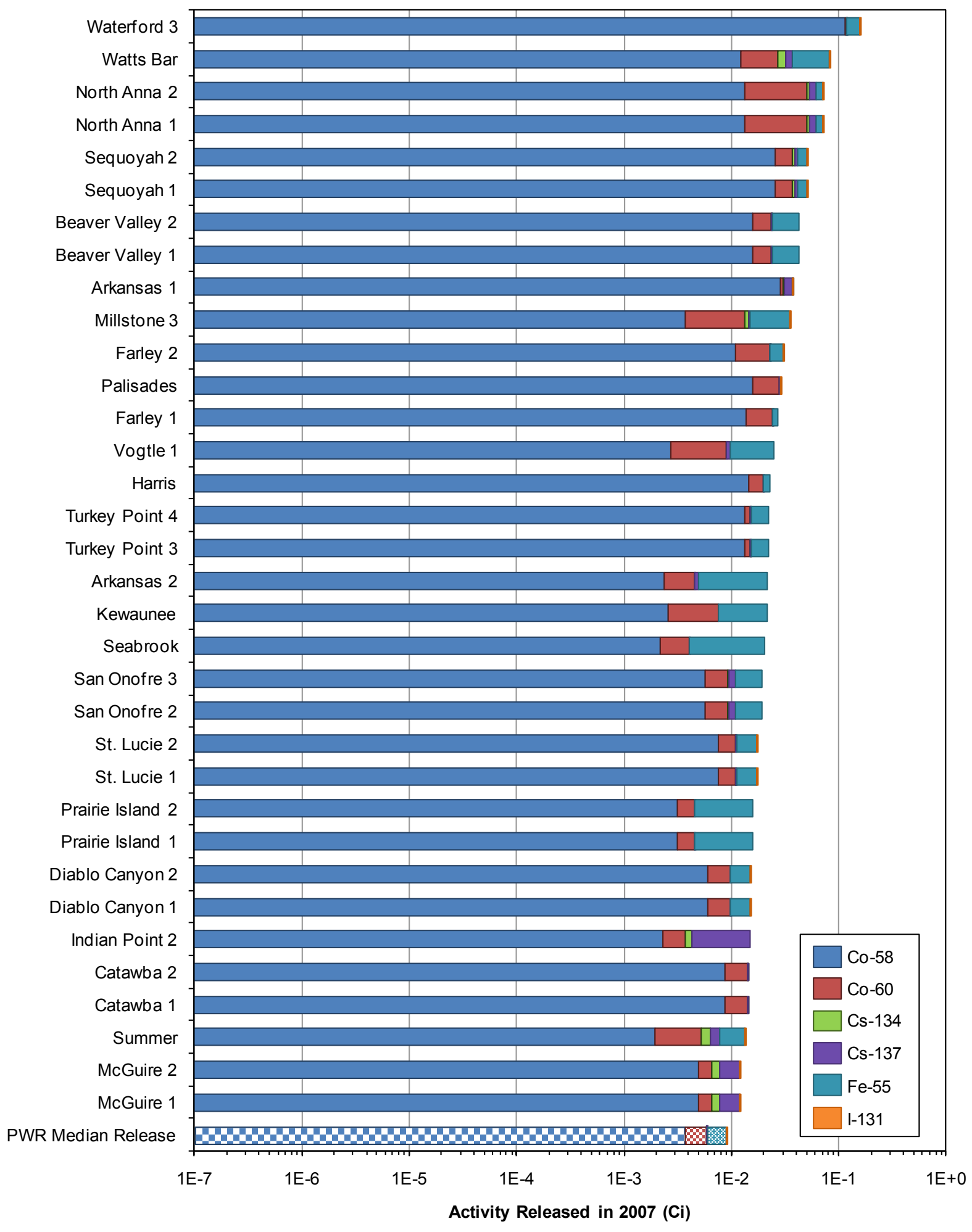


FIGURE 4.11 (continued)

\section{PWR Liquid Releases - Selected Fission and Activation Products}

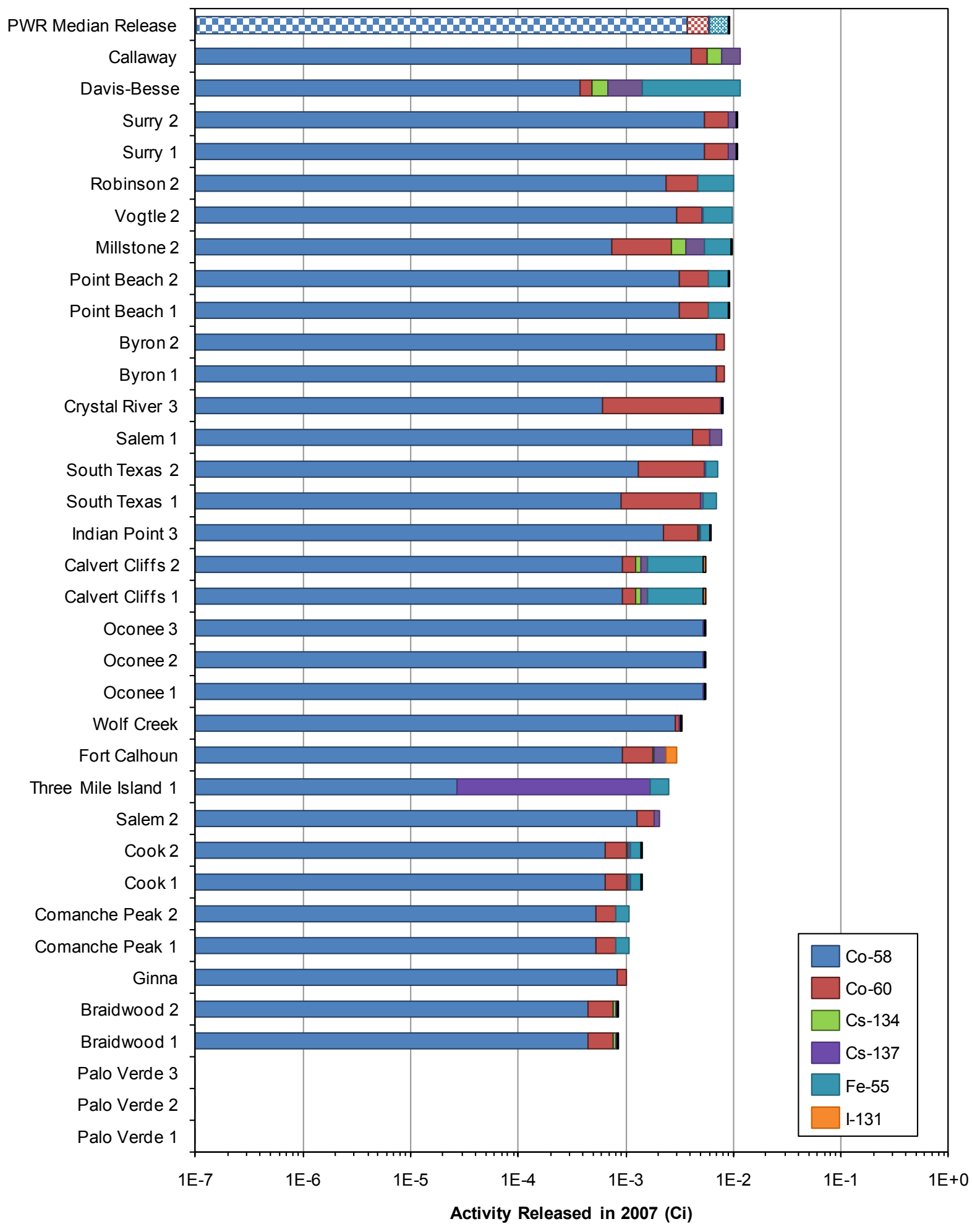


FIGURE 4.12

PWR Liquid Releases - Tritium

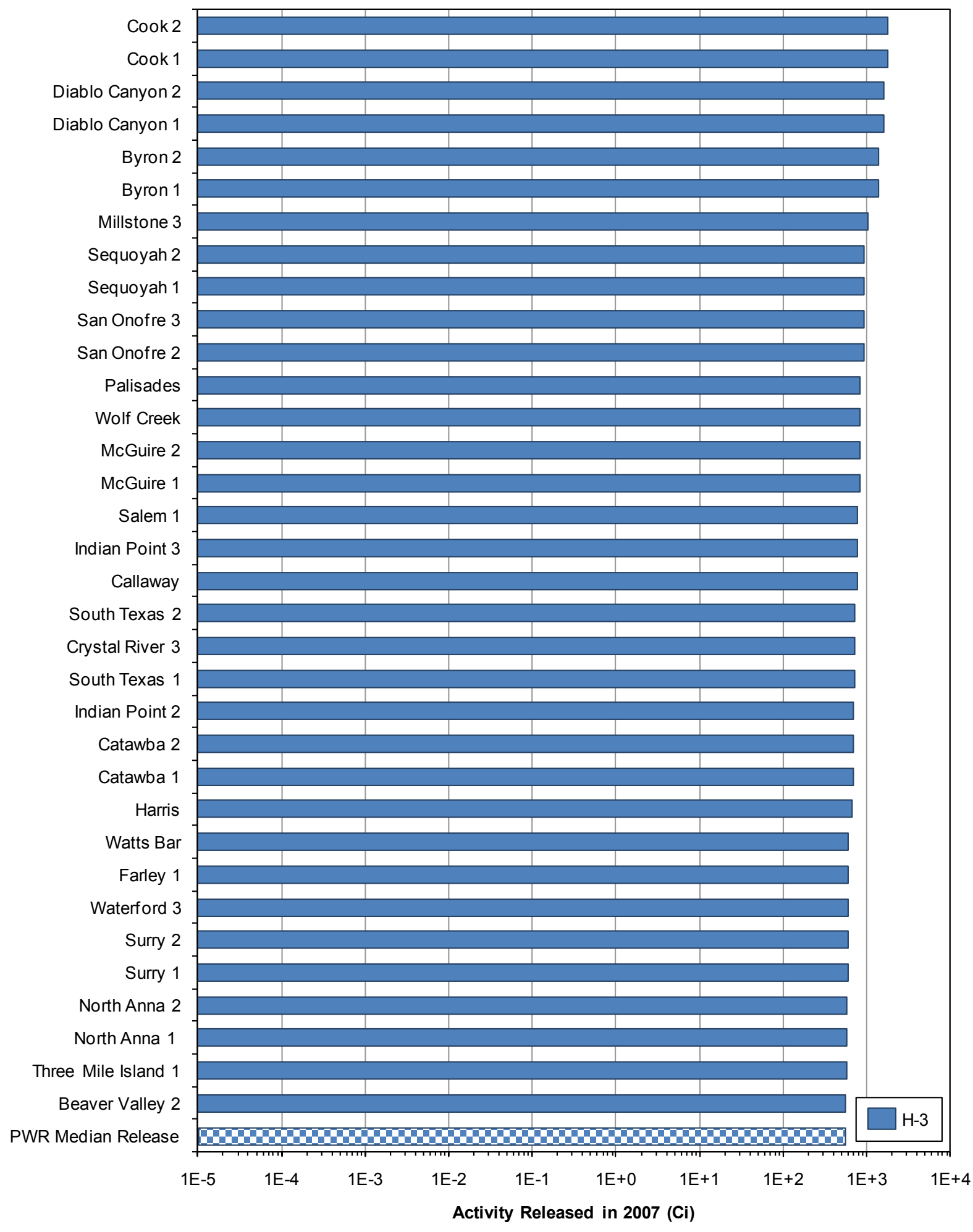


FIGURE 4.12 (continued) PWR Liquid Releases - Tritium

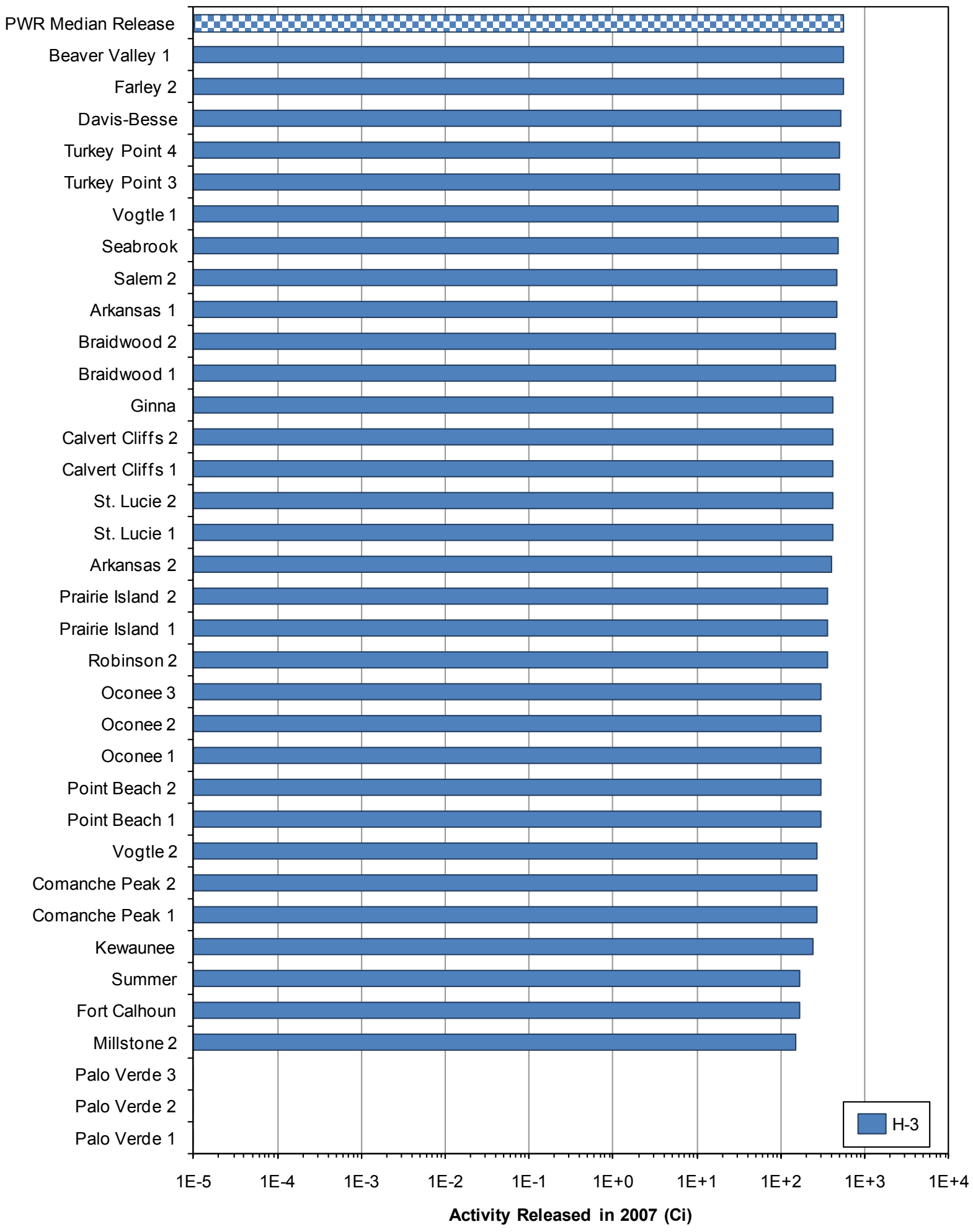




\subsection{RADIATION DOSE}

TABLE 4.13

BWR Gaseous Effluents — Maximum Annual Organ Dose, 2007

\begin{tabular}{|l|c|}
\hline \multicolumn{1}{|c|}{ BWR Facility } & $\begin{array}{c}\text { Annual Organ } \\
\text { Dose (mrem) }\end{array}$ \\
\hline Perry & $8.29 \mathrm{E}-05$ \\
\hline Clinton & $8.17 \mathrm{E}-04$ \\
\hline Vermont Yankee & $1.48 \mathrm{E}-03$ \\
\hline Browns Ferry 1 & $3.33 \mathrm{E}-03$ \\
\hline Browns Ferry 2 & $3.33 \mathrm{E}-03$ \\
\hline Browns Ferry 3 & $3.33 \mathrm{E}-03$ \\
\hline Dresden 2 & $3.61 \mathrm{E}-03$ \\
\hline Limerick 1 & $5.15 \mathrm{E}-03$ \\
\hline Limerick 2 & $5.15 \mathrm{E}-03$ \\
\hline Duane Arnold & $1.00 \mathrm{E}-02$ \\
\hline Monticello & $1.05 \mathrm{E}-02$ \\
\hline Dresden 3 & $1.13 \mathrm{E}-02$ \\
\hline Hope Creek & $1.22 \mathrm{E}-02$ \\
\hline Oyster Creek & $1.34 \mathrm{E}-02$ \\
\hline Hatch 1 & $1.55 \mathrm{E}-02$ \\
\hline Hatch 2 & $1.99 \mathrm{E}-02$ \\
\hline Columbia Generating & $2.40 \mathrm{E}-02$ \\
\hline Nine Mile Point 1 & $3.10 \mathrm{E}-02$ \\
\hline Nine Mile Point 2 & $3.10 \mathrm{E}-02$ \\
\hline Fitzpatrick & $3.10 \mathrm{E}-02$ \\
\hline Cooper Station & $6.34 \mathrm{E}-02$ \\
\hline LaSalle 1 & $7.35 \mathrm{E}-02$ \\
\hline LaSalle 2 & $7.35 \mathrm{E}-02$ \\
\hline Fermi 2 & $7.58 \mathrm{E}-02$ \\
\hline Quad Cities 1 & $1.28 \mathrm{E}-01$ \\
\hline Quad Cities 2 & $1.28 \mathrm{E}-01$ \\
\hline Pilgrim & $1.60 \mathrm{E}-01$ \\
\hline Brunswick 1 & $2.31 \mathrm{E}-01$ \\
\hline Brunswick 2 & $2.31 \mathrm{E}-01$ \\
\hline Susquehanna 1 & $3.88 \mathrm{E}-01$ \\
\hline Susquehanna 2 & $4.06 \mathrm{E}-01$ \\
\hline Grand Gulf & $7.39 \mathrm{E}-01$ \\
\hline River Bend & $7.47 \mathrm{E}-01$ \\
\hline Peach Bottom 2 & $8.88 \mathrm{E}-01$ \\
\hline Peach Bottom 3 & $8.88 \mathrm{E}-01$ \\
\hline Gaseous Effluent Operational Limit & $1.50 \mathrm{E}+01$ \\
\hline & \\
\hline
\end{tabular}


TABLE 4.14

PWR Gaseous Effluents — Maximum Annual Organ Dose, 2007

\begin{tabular}{|l|c|}
\hline \multicolumn{1}{|c|}{ PWR Facility } & $\begin{array}{c}\text { Annual Organ } \\
\text { Dose (mrem) }\end{array}$ \\
\hline Ginna & $1.49 \mathrm{E}-06$ \\
\hline Vogtle 2 & $6.75 \mathrm{E}-05$ \\
\hline Turkey Point 4 & $1.71 \mathrm{E}-04$ \\
\hline Turkey Point 3 & $2.04 \mathrm{E}-04$ \\
\hline Kewaunee & $2.58 \mathrm{E}-04$ \\
\hline Vogtle 1 & $3.93 \mathrm{E}-04$ \\
\hline Diablo Canyon 2 & $8.32 \mathrm{E}-04$ \\
\hline South Texas 1 & $8.68 \mathrm{E}-04$ \\
\hline Salem 1 & $1.02 \mathrm{E}-03$ \\
\hline Salem 2 & $1.02 \mathrm{E}-03$ \\
\hline South Texas 2 & $1.15 \mathrm{E}-03$ \\
\hline Davis-Besse & $1.30 \mathrm{E}-03$ \\
\hline Farley 2 & $1.36 \mathrm{E}-03$ \\
\hline Summer & $2.31 \mathrm{E}-03$ \\
\hline Indian Point 2 & $2.43 \mathrm{E}-03$ \\
\hline Farley 1 & $3.22 \mathrm{E}-03$ \\
\hline Diablo Canyon 1 & $3.76 \mathrm{E}-03$ \\
\hline Byron 2 & $3.86 \mathrm{E}-03$ \\
\hline Indian Point 3 & $3.88 \mathrm{E}-03$ \\
\hline Crystal River 3 & $4.07 \mathrm{E}-03$ \\
\hline Millstone 2 & $4.88 \mathrm{E}-03$ \\
\hline St. Lucie 1 & $6.71 \mathrm{E}-03$ \\
\hline Callaway & $7.65 \mathrm{E}-03$ \\
\hline Three Mile Island 1 & $8.14 \mathrm{E}-03$ \\
\hline San Onofre 2 & $8.58 \mathrm{E}-03$ \\
\hline San Onofre 3 & $8.58 \mathrm{E}-03$ \\
\hline Fort Calhoun & $8.58 \mathrm{E}-03$ \\
\hline Byron 1 & $8.67 \mathrm{E}-03$ \\
\hline Prairie Island 1 & $1.63 \mathrm{E}-02$ \\
\hline Prairie Island 2 & $1.63 \mathrm{E}-02$ \\
\hline Point Beach 1 & $1.72 \mathrm{E}-02$ \\
\hline Point Beach 2 & $1.72 \mathrm{E}-02$ \\
\hline Seabrook & $1.85 \mathrm{E}-02$ \\
\hline Arkansas 1 & $2.03 \mathrm{E}-02$ \\
\hline Arkansas 2 & $2.38 \mathrm{E}-02$ \\
\hline North Anna 1 & $2.54 \mathrm{E}-02$ \\
\hline & \\
\hline
\end{tabular}

\begin{tabular}{|l|c|}
\hline \multicolumn{1}{|c|}{ PWR Facility } & $\begin{array}{c}\text { Annual Organ } \\
\text { Dose (mrem) }\end{array}$ \\
\hline North Anna 2 & $2.54 \mathrm{E}-02$ \\
\hline Oconee 1 & $2.56 \mathrm{E}-02$ \\
\hline Oconee 2 & $2.56 \mathrm{E}-02$ \\
\hline Oconee 3 & $2.56 \mathrm{E}-02$ \\
\hline Wolf Creek & $3.05 \mathrm{E}-02$ \\
\hline Sequoyah 1 & $3.70 \mathrm{E}-02$ \\
\hline Sequoyah 2 & $3.70 \mathrm{E}-02$ \\
\hline Comanche Peak 1 & $3.94 \mathrm{E}-02$ \\
\hline Comanche Peak 2 & $3.94 \mathrm{E}-02$ \\
\hline Watts Bar & $3.96 \mathrm{E}-02$ \\
\hline Braidwood 1 & $3.99 \mathrm{E}-02$ \\
\hline Calvert Cliffs 1 & $6.50 \mathrm{E}-02$ \\
\hline Calvert Cliffs 2 & $6.50 \mathrm{E}-02$ \\
\hline Braidwood 2 & $6.98 \mathrm{E}-02$ \\
\hline Surry 1 & $7.60 \mathrm{E}-02$ \\
\hline Surry 2 & $7.60 \mathrm{E}-02$ \\
\hline Robinson 2 & $9.22 \mathrm{E}-02$ \\
\hline Beaver Valley 2 & $9.46 \mathrm{E}-02$ \\
\hline Waterford 3 & $1.20 \mathrm{E}-01$ \\
\hline McGuire 1 & $1.22 \mathrm{E}-01$ \\
\hline McGuire 2 & $1.22 \mathrm{E}-01$ \\
\hline Millstone 3 & $1.23 \mathrm{E}-01$ \\
\hline Cook 1 & $1.33 \mathrm{E}-01$ \\
\hline Cook 2 & $1.33 \mathrm{E}-01$ \\
\hline St. Lucie 2 & $1.37 \mathrm{E}-01$ \\
\hline Palo Verde 2 & $2.08 \mathrm{E}-01$ \\
\hline Palo Verde 1 & $2.17 \mathrm{E}-01$ \\
\hline Palo Verde 3 & $2.74 \mathrm{E}-01$ \\
\hline Beaver Valley 1 & $2.80 \mathrm{E}-01$ \\
\hline Harris & $3.18 \mathrm{E}-01$ \\
\hline Palisades & $3.72 \mathrm{E}-01$ \\
\hline Catawba 1 & $4.48 \mathrm{E}-01$ \\
\hline Catawba 2 & $4.48 \mathrm{E}-01$ \\
\hline Gaseous Effluent & $\mathbf{1 . 5 0 E + 0 1}$ \\
\hline Operational Limit & \\
\hline &
\end{tabular}


TABLE 4.15

BWR Liquid Effluents — Maximum Annual Total Body and Organ Dose, 2007

\begin{tabular}{|l|c|c|}
\multicolumn{1}{|c|}{ BWR Facility } & $\begin{array}{c}\text { Annual Total } \\
\text { Body Dose } \\
\text { (mrem) }\end{array}$ & $\begin{array}{c}\text { Annual } \\
\text { Organ Dose } \\
\text { (mrem) }\end{array}$ \\
\hline Clinton & & \\
\hline Columbia Generating & & \\
\hline Cooper Station & & \\
\hline Fermi 2 & & \\
\hline LaSalle 1 & & \\
\hline LaSalle 2 & & \\
\hline Nine Mile Point 1 & & \\
\hline Nine Mile Point 2 & & \\
\hline Oyster Creek & & \\
\hline Vermont Yankee & $4.86 \mathrm{E}-06$ & $7.57 \mathrm{E}-06$ \\
\hline Pilgrim & $1.96 \mathrm{E}-05$ & $1.98 \mathrm{E}-05$ \\
\hline Fitzpatrick & $2.25 \mathrm{E}-05$ & $2.25 \mathrm{E}-05$ \\
\hline Duane Arnold & $1.97 \mathrm{E}-05$ & $3.47 \mathrm{E}-05$ \\
\hline Dresden 3 & $2.85 \mathrm{E}-05$ & $1.22 \mathrm{E}-04$ \\
\hline Hope Creek & $9.00 \mathrm{E}-05$ & $6.75 \mathrm{E}-04$ \\
\hline River Bend & $2.79 \mathrm{E}-04$ & $6.35 \mathrm{E}-04$ \\
\hline Brunswick 1 & $2.79 \mathrm{E}-04$ & $6.35 \mathrm{E}-04$ \\
\hline Brunswick 2 & $7.40 \mathrm{E}-04$ & $8.21 \mathrm{E}-04$ \\
\hline Perry & $9.23 \mathrm{E}-04$ & $1.01 \mathrm{E}-03$ \\
\hline Hatch 2 & $9.96 \mathrm{E}-04$ & $1.01 \mathrm{E}-03$ \\
\hline Dresden 2 & $1.02 \mathrm{E}-03$ & $1.66 \mathrm{E}-03$ \\
\hline Quad Cities 1 & $1.02 \mathrm{E}-03$ & $1.66 \mathrm{E}-03$ \\
\hline Quad Cities 2 & $9.05 \mathrm{E}-04$ & $1.85 \mathrm{E}-03$ \\
\hline Susquehanna 1 & $9.05 \mathrm{E}-04$ & $1.85 \mathrm{E}-03$ \\
\hline Susquehanna 2 & $1.91 \mathrm{E}-03$ & $2.54 \mathrm{E}-03$ \\
\hline Limerick 1 & $1.91 \mathrm{E}-03$ & $2.54 \mathrm{E}-03$ \\
\hline Limerick 2 & $2.90 \mathrm{E}-03$ & $5.92 \mathrm{E}-03$ \\
\hline Monticello & $9.26 \mathrm{E}-03$ & $1.67 \mathrm{E}-02$ \\
\hline Hatch 1 & $7.51 \mathrm{E}-03$ & $1.85 \mathrm{E}-02$ \\
\hline Peach Bottom 2 & $7.51 \mathrm{E}-03$ & $1.85 \mathrm{E}-02$ \\
\hline Peach Bottom 3 & $1.26 \mathrm{E}-02$ & $1.79 \mathrm{E}-02$ \\
\hline Browns Ferry 1 & $1.26 \mathrm{E}-02$ & $1.79 \mathrm{E}-02$ \\
\hline Browns Ferry 2 & $1.26 \mathrm{E}-02$ & $1.79 \mathrm{E}-02$ \\
\hline Browns Ferry 3 & $1.57 \mathrm{E}-01$ & $4.72 \mathrm{E}-01$ \\
\hline Grand Gulf & $3.00 \mathrm{E}+00$ & $\mathbf{1 . 0 0 E}+01$ \\
\hline Liquid Effluent Operational Limit & & \\
\hline & & \\
\hline
\end{tabular}


TABLE 4.16

PWR Liquid Effluents — Maximum Annual Total Body and Organ Dose, 2007

\begin{tabular}{|c|c|c|c|c|c|}
\hline PWR Facility & $\begin{array}{c}\text { Annual } \\
\text { Total Body } \\
\text { Dose } \\
\text { (mrem) }\end{array}$ & $\begin{array}{l}\text { Annual } \\
\text { Organ } \\
\text { Dose } \\
\text { (mrem) }\end{array}$ & PWR Facility & $\begin{array}{c}\text { Annual } \\
\text { Total Body } \\
\text { Dose } \\
\text { (mrem) }\end{array}$ & $\begin{array}{c}\text { Annual } \\
\text { Organ } \\
\text { Dose } \\
(\mathrm{mrem})\end{array}$ \\
\hline Palo Verde 1 & & & Davis-Besse & 8.99E-03 & $1.19 \mathrm{E}-02$ \\
\hline Palo Verde 2 & & & St. Lucie 1 & $5.08 \mathrm{E}-03$ & $1.96 \mathrm{E}-02$ \\
\hline Palo Verde 3 & & & St. Lucie 2 & 5.08E-03 & 1.96E-02 \\
\hline Ginna & 3.27E-06 & $3.33 \mathrm{E}-06$ & Sequoyah 1 & 1.43E-02 & 1.70E-02 \\
\hline Salem 2 & $2.90 \mathrm{E}-05$ & $3.32 \mathrm{E}-05$ & Sequoyah 2 & 1.43E-02 & 1.70E-02 \\
\hline Turkey Point 3 & 8.40E-05 & & Harris & 1.55E-02 & 1.99E-02 \\
\hline Turkey Point 4 & $8.40 \mathrm{E}-05$ & & Fort Calhoun & 1.68E-02 & $2.01 \mathrm{E}-02$ \\
\hline Salem 1 & 3.57E-05 & $5.12 \mathrm{E}-05$ & Vogtle 1 & $1.58 \mathrm{E}-02$ & $2.26 \mathrm{E}-02$ \\
\hline Robinson 2 & $9.77 \mathrm{E}-05$ & 1.13E-04 & Callaway & 2.16E-02 & 2.96E-02 \\
\hline Crystal River 3 & 2.91E-05 & $1.85 \mathrm{E}-04$ & Oconee 1 & $2.56 \mathrm{E}-02$ & $2.86 \mathrm{E}-02$ \\
\hline Surry 1 & 1.43E-04 & 2.93E-04 & Oconee 2 & 2.56E-02 & $2.86 \mathrm{E}-02$ \\
\hline Surry 2 & 1.43E-04 & 2.93E-04 & Oconee 3 & $2.56 \mathrm{E}-02$ & $2.86 \mathrm{E}-02$ \\
\hline Indian Point 3 & $2.14 \mathrm{E}-04$ & $3.20 \mathrm{E}-04$ & Farley 1 & 8.36E-03 & $5.01 \mathrm{E}-02$ \\
\hline Millstone 2 & 1.65E-04 & $9.11 \mathrm{E}-04$ & Farley 2 & $6.83 \mathrm{E}-03$ & $6.75 \mathrm{E}-02$ \\
\hline Diablo Canyon 1 & $5.20 \mathrm{E}-04$ & 1.00E-03 & Catawba 1 & $3.60 \mathrm{E}-02$ & $4.38 \mathrm{E}-02$ \\
\hline Diablo Canyon 2 & $5.20 \mathrm{E}-04$ & 1.00E-03 & Catawba 2 & $3.60 \mathrm{E}-02$ & $4.38 \mathrm{E}-02$ \\
\hline Seabrook & 3.16E-04 & $1.25 \mathrm{E}-03$ & Cook 1 & 4.54E-02 & 4.57E-02 \\
\hline Arkansas 2 & 8.00E-04 & $9.00 \mathrm{E}-04$ & Cook 2 & 4.54E-02 & 4.57E-02 \\
\hline Indian Point 2 & $5.35 \mathrm{E}-04$ & $1.30 \mathrm{E}-03$ & Watts Bar & 4.47E-02 & 5.77E-02 \\
\hline Prairie Island 1 & 8.60E-04 & $1.25 \mathrm{E}-03$ & Beaver Valley 1 & 4.37E-02 & $6.30 \mathrm{E}-02$ \\
\hline Prairie Island 2 & $8.60 \mathrm{E}-04$ & $1.25 \mathrm{E}-03$ & Beaver Valley 2 & 4.37E-02 & $6.30 \mathrm{E}-02$ \\
\hline Calvert Cliffs 1 & $6.00 \mathrm{E}-04$ & $1.55 \mathrm{E}-03$ & Three Mile Island 1 & $5.68 \mathrm{E}-02$ & $7.25 \mathrm{E}-02$ \\
\hline Calvert Cliffs 2 & $6.00 \mathrm{E}-04$ & $1.55 \mathrm{E}-03$ & Comanche Peak 1 & $6.84 \mathrm{E}-02$ & $6.84 \mathrm{E}-02$ \\
\hline Millstone 3 & 7.64E-04 & $2.14 \mathrm{E}-03$ & Comanche Peak 2 & $6.84 \mathrm{E}-02$ & $6.84 \mathrm{E}-02$ \\
\hline Kewaunee & 1.30E-03 & $1.78 \mathrm{E}-03$ & Byron 1 & 7.79E-02 & 1.16E-01 \\
\hline Summer & $1.61 \mathrm{E}-03$ & 1.87E-03 & Byron 2 & 7.79E-02 & 1.16E-01 \\
\hline Waterford 3 & $1.24 \mathrm{E}-03$ & 2.31E-03 & Wolf Creek & 1.10E-01 & $1.11 \mathrm{E}-01$ \\
\hline Point Beach 1 & 3.10E-03 & 3.15E-03 & McGuire 1 & 1.03E-01 & $1.25 \mathrm{E}-01$ \\
\hline Point Beach 2 & 3.10E-03 & $3.15 \mathrm{E}-03$ & McGuire 2 & 1.03E-01 & $1.25 \mathrm{E}-01$ \\
\hline South Texas 1 & 4.07E-03 & 4.13E-03 & Braidwood 1 & 1.45E-01 & $1.45 \mathrm{E}-01$ \\
\hline South Texas 2 & $4.14 \mathrm{E}-03$ & $4.19 \mathrm{E}-03$ & Braidwood 2 & $1.45 \mathrm{E}-01$ & $1.45 \mathrm{E}-01$ \\
\hline Arkansas 1 & $3.60 \mathrm{E}-03$ & $5.20 \mathrm{E}-03$ & North Anna 1 & 3.11E-01 & $4.18 \mathrm{E}-01$ \\
\hline San Onofre 2 & $2.42 \mathrm{E}-03$ & $6.75 \mathrm{E}-03$ & North Anna 2 & $3.11 \mathrm{E}-01$ & 4.18E-01 \\
\hline San Onofre 3 & $2.42 \mathrm{E}-03$ & $6.75 \mathrm{E}-03$ & Liquid Effluent & & $100 \mathrm{~F}+01$ \\
\hline Vogtle 2 & $4.87 \mathrm{E}-03$ & $9.83 \mathrm{E}-03$ & & $3.00 E+00$ & \\
\hline Palisades & $6.47 \mathrm{E}-03$ & 8.60E-03 & & & \\
\hline
\end{tabular}


FIGURE 4.13

BWR Gaseous Effluents - Maximum Annual Organ Dose

Gaseous Effluent Operational Limit

Peach Bottom 3

Peach Bottom 2

River Bend

Grand Gulf

Susquehanna 2

Susquehanna 1

Brunswick 2

Brunswick 1

Pilgrim

Quad Cities 2

Quad Cities 1

Fermi 2

LaSalle 2

LaSalle 1

Cooper Station

Fitzpatrick

Nine Mile Point 2

Nine Mile Point 1

Columbia Generating

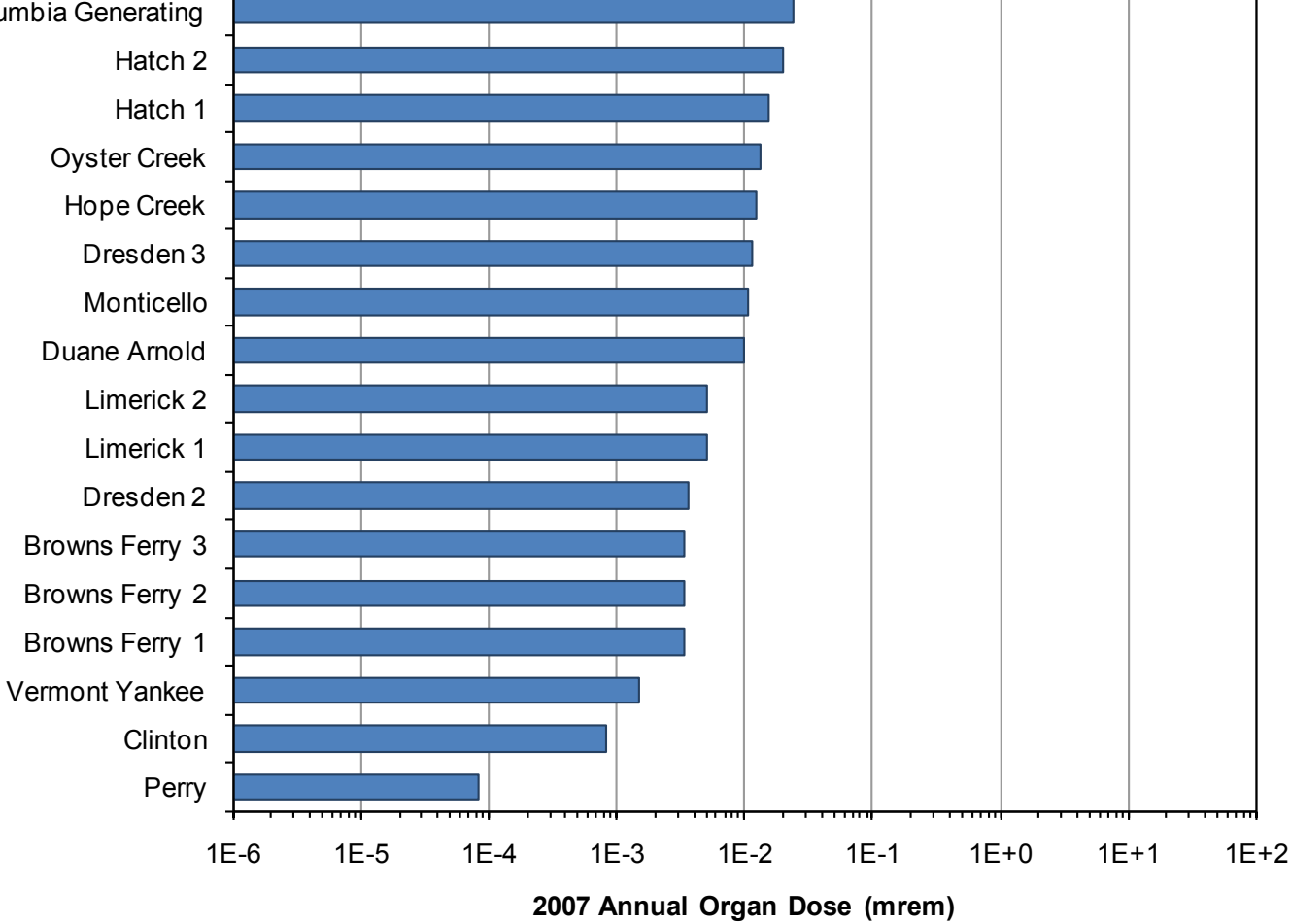


FIGURE 4.14

PWR Gaseous Effluents - Maximum Annual Organ Dose

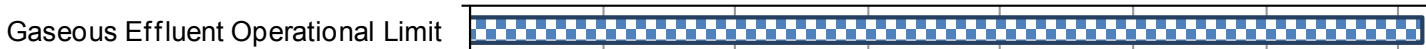

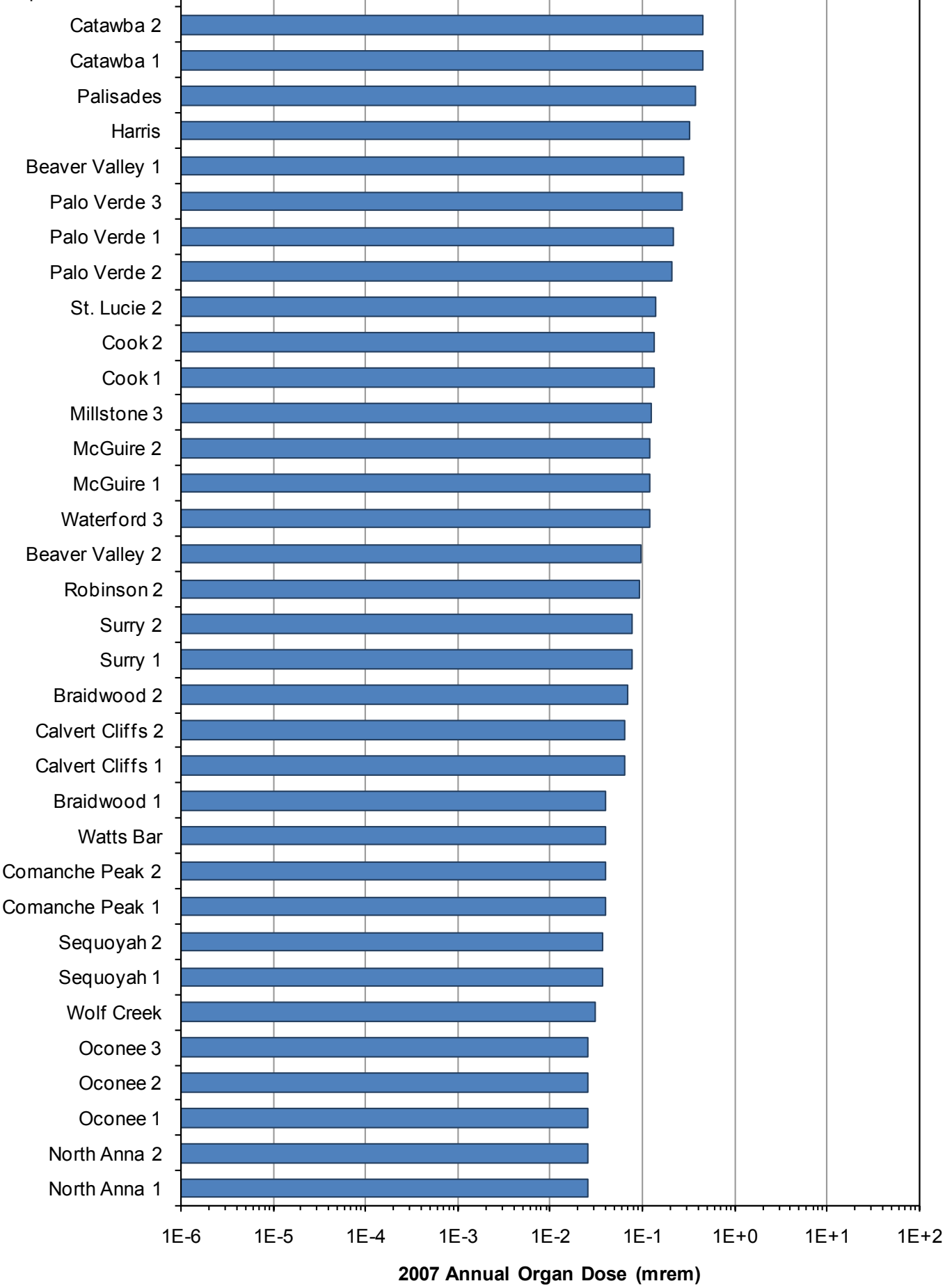


FIGURE 4.14 (continued)

PWR Gaseous Effluents - Maximum Annual Organ Dose

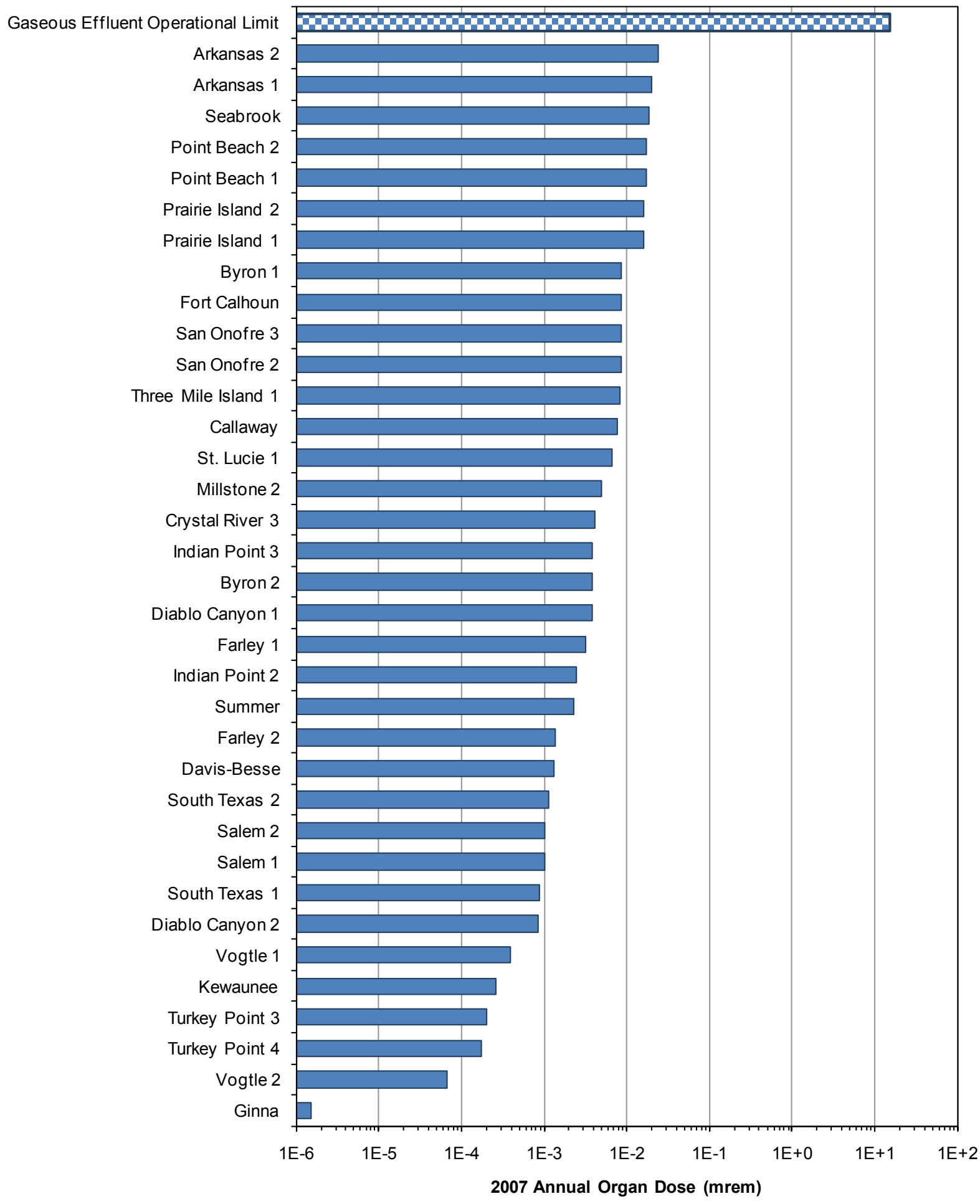


FIGURE 4.15

BWR Liquid Effluents - Maximum Annual Total Body and Organ Dose

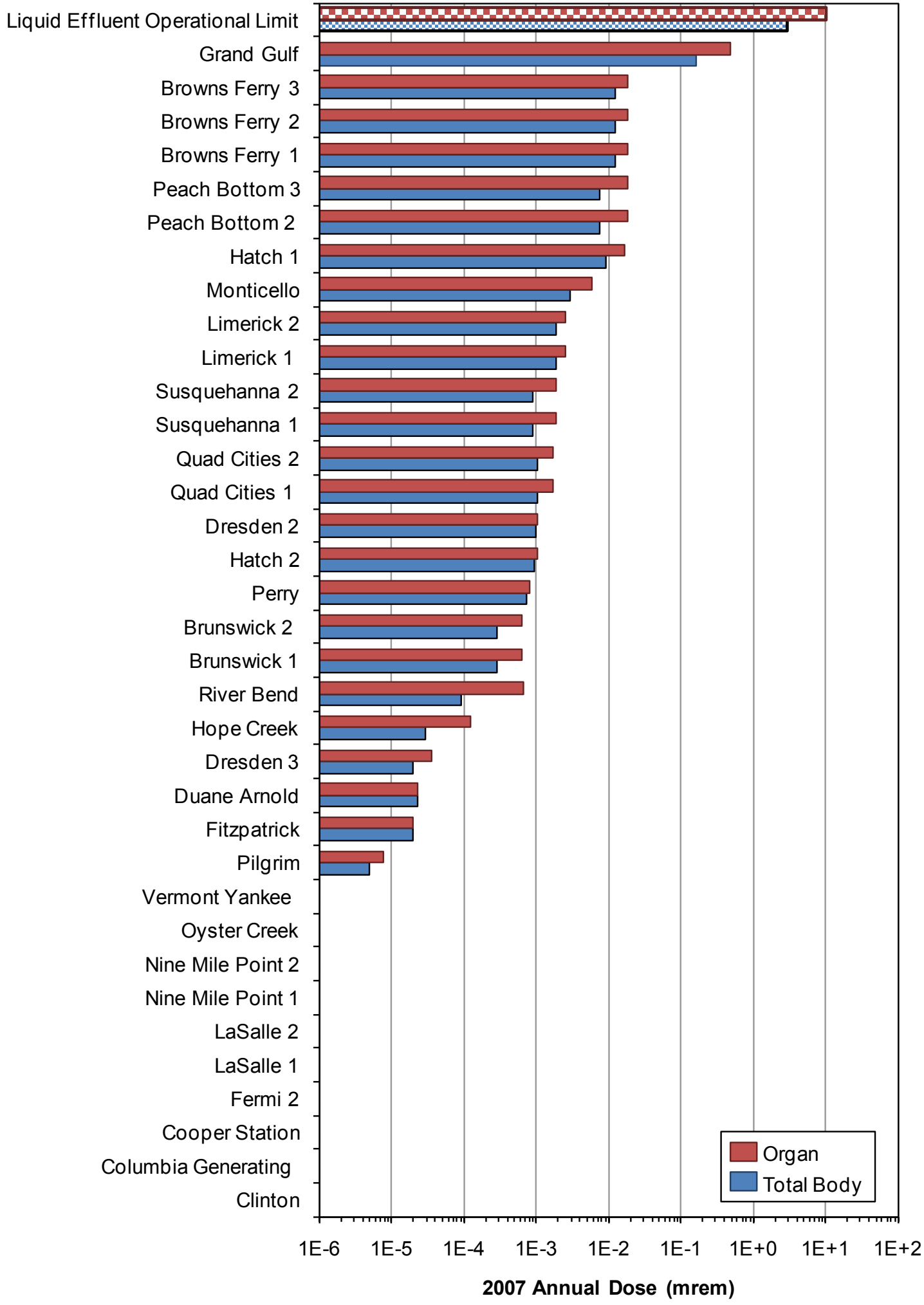


FIGURE 4.16

PWR Liquid Effluents - Maximum Annual Total Body and Organ Dose

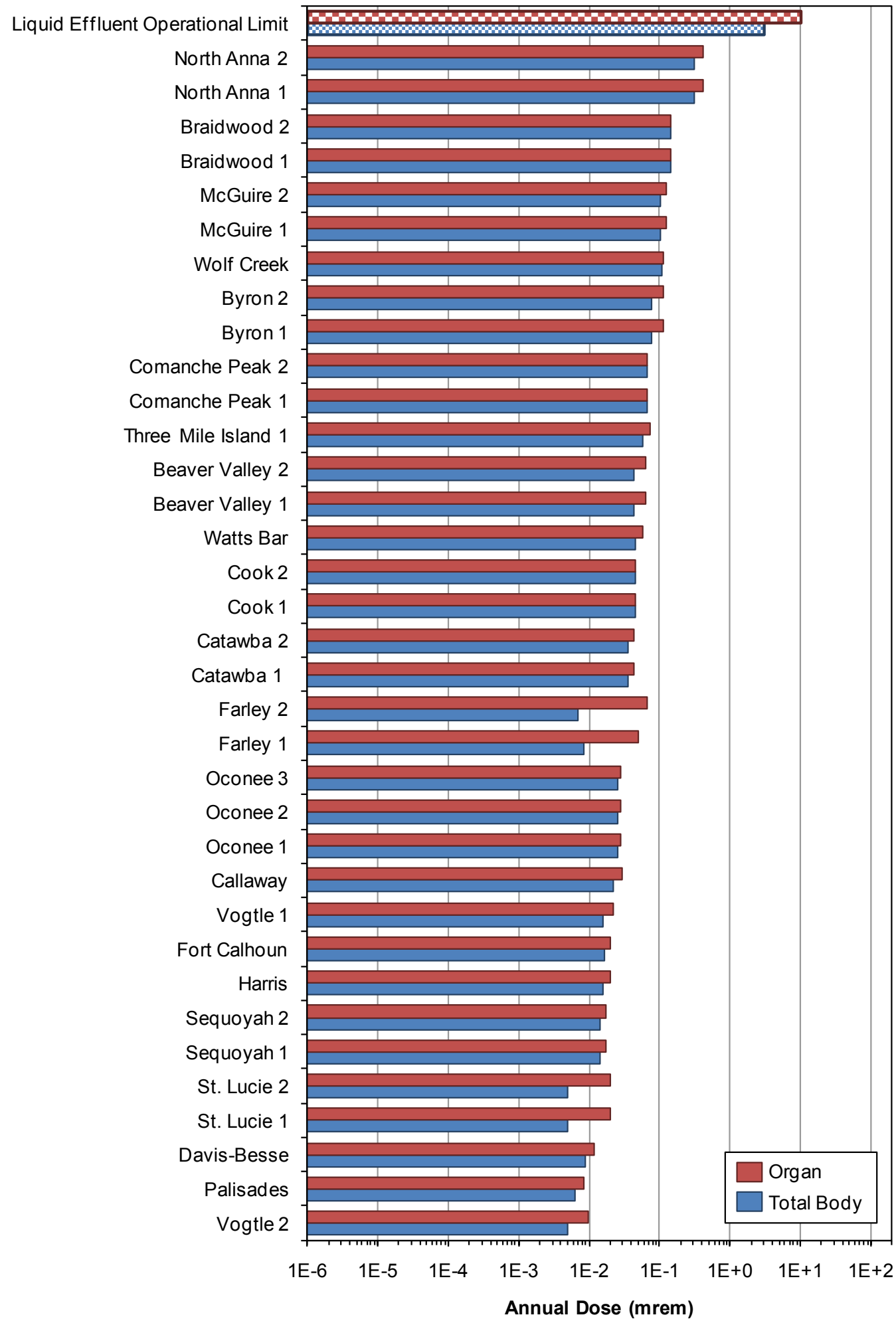


FIGURE 4.16 (continued) PWR Liquid Effluents - Maximum Annual Total Body and Organ Dose

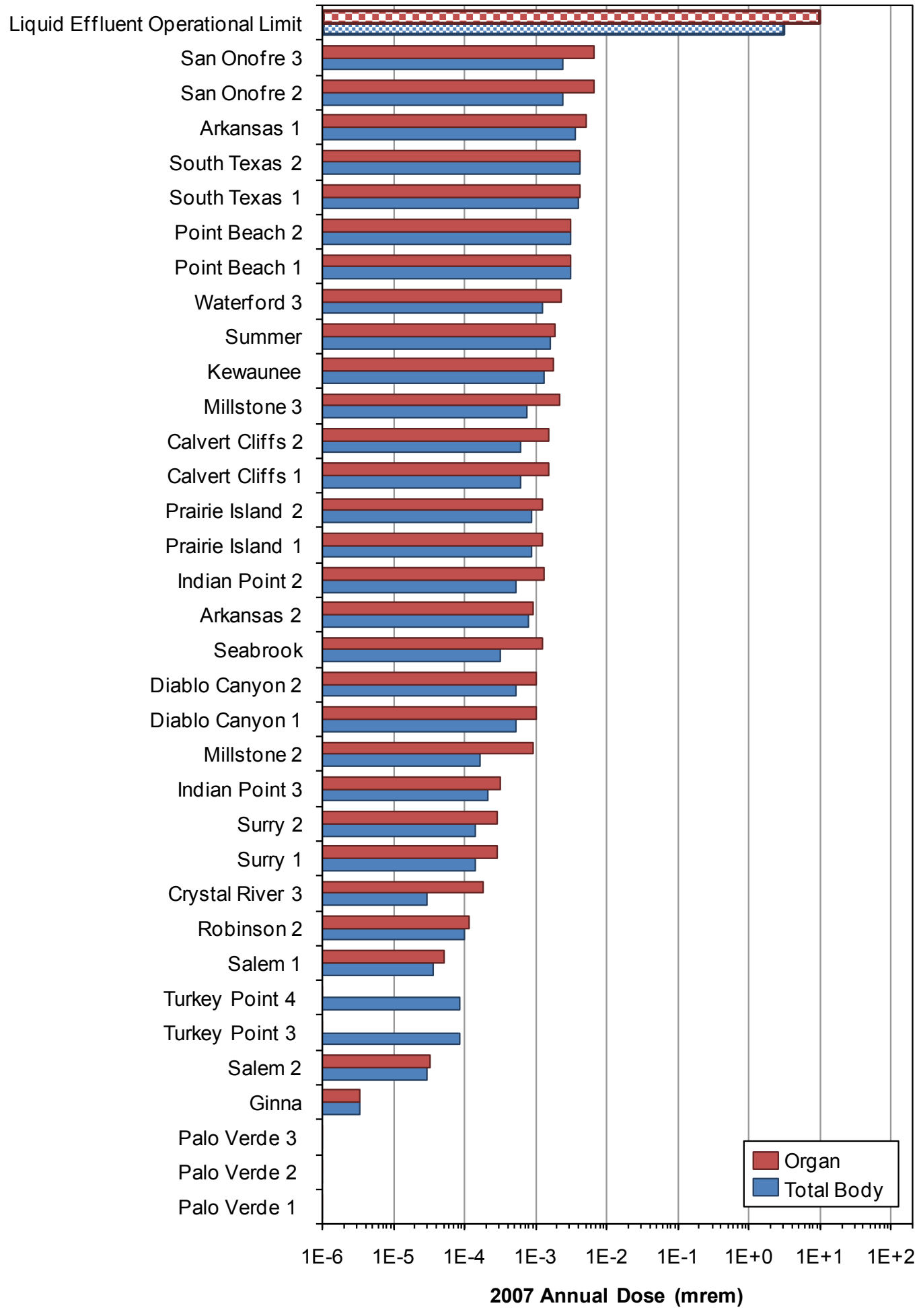




\section{Section 5 \\ REFERENCES}

1. "Report on Releases of Radioactivity in Effluents and Solid Wastes from Nuclear Power Plants for 1972," Directorate of Regulatory Operations, August 1973.

2. "Summary of Radioactivity Releases in Effluents from Nuclear Power Plants During 1973," NUREG-75/001, January 1975.

3. "Radioactive Materials Released from Nuclear Power Plants, 1974," NUREG-0077, June 1976.

4. "Radioactive Materials Released from Nuclear Power Plants, 1975," NUREG-0218, March 1977.

5. "Radioactive Materials Released from Nuclear Power Plants, 1976," NUREG-0367, March 1978.

6. "Radioactive Materials Released from Nuclear Power Plants, 1977," NUREG-0521, January 1979.

7. "Radioactive Materials Released from Nuclear Power Plants, 1978," NUREG/CR-1497, BNL-NUREG-51192, March 1981.

8. "Radioactive Materials Released from Nuclear Power Plants, 1979," NUREG/CR-2227, BNL-NUREG-51416, November 1981.

9. "Radioactive Materials Released from Nuclear Power Plants, 1980," NUREG/CR-2907, BNL-NUREG-51581, Vol. 1, January 1983.

10. "Radioactive Materials Released from Nuclear Power Plants, 1981," NUREG/CR-2907, BNL-NUREG-51581, Vol. 2, June 1984.

11. "Radioactive Materials Released from Nuclear Power Plants, 1982," NUREG/CR-2907, BNL-NUREG-51581, Vol. 3, February 1986.

12. "Radioactive Materials Released from Nuclear Power Plants, 1983," NUREG/CR-2907, BNL-NUREG-51581, Vol. 4, August 1986.

13. "Radioactive Materials Released from Nuclear Power Plants, 1984," NUREG/CR-2907, BNL-NUREG-51581, Vol. 5, August 1987.

14. "Radioactive Materials Released from Nuclear Power Plants, 1985," NUREG/CR-2907, BNL-NUREG-51581, Vol. 6, January 1988.

15. "Radioactive Materials Released from Nuclear Power Plants, 1986," NUREG/CR-2907, BNL-NUREG-51581, Vol. 7, November 1988.

16. "Radioactive Materials Released from Nuclear Power Plants, 1987," NUREG/CR-2907, BNL-NUREG-51581, Vol. 8, October 1989. 
17. "Radioactive Materials Released from Nuclear Power Plants, 1988," NUREG/CR-2907, BNL-NUREG-51581, Vol. 9, July 1991.

18. "Radioactive Materials Released from Nuclear Power Plants, 1989," NUREG/CR-2907, BNL-NUREG-51581, Vol. 10, September 1992.

19. "Radioactive Materials Released from Nuclear Power Plants, 1990," NUREG/CR-2907, BNL-NUREG-51581, Vol. 11, October 1993.

20. "Radioactive Materials Released from Nuclear Power Plants, 1991," NUREG/CR-2907, BNL-NUREG-51581, Vol. 12, May 1994.

21. "Radioactive Materials Released from Nuclear Power Plants, 1992," NUREG/CR-2907, BNL-NUREG-51581, Vol. 13, August 1995.

22. "Radioactive Materials Released from Nuclear Power Plants, 1993," NUREG/CR-2907, BNL-NUREG-51581, Vol. 14, August 1995.

23. SECY-06-0212, Preparation of Annual Reports on Radioactive Materials Released in Gaseous and Liquid Effluents and in Solid Wastes Shipped for Disposal by Commercial Nuclear Power Plants, U.S. Nuclear Regulatory Commission, Washington, DC, October 17, 2006.

24. 10 CFR Part 50, "Domestic Licensing of Production and Utilization Facilities," U.S. Nuclear Regulatory Commission, Washington, DC.

25. Regulatory Guide 1.21, "Measuring, Evaluating, and Reporting Radioactive Material in Liquid and Gaseous Effluents and Solid Waste," Revision 2, U.S. Nuclear Regulatory Commission, Washington, DC, June 2009.

26. Regulatory Guide 1.109, "Calculation of Annual Doses to Man from Routine Releases of Reactor Effluents for the Purpose of Demonstrating Compliance with 10 CFR Part 50, Appendix I," U.S. Nuclear Regulatory Commission, Washington, DC, October 1977.

27. 10 CFR Part 20, "Standards for Protection Against Radiation," U.S. Nuclear Regulatory Commission, Washington, DC.

28. NCRP Publication No. 160, "Ionizing Radiation Exposure of the Population of the United States, National Council on Radiation Protection and Measurements”, Bethesda, MD, March 3, 2009.

29. NCRP Publication No. 93, "Ionizing Radiation Exposure of the Population of the United States, National Council on Radiation Protection and Measurements", Bethesda, MD, September 1987. 


\section{AVAILABILITY OF REFERENCE MATERIALS IN NRC PUBLICATIONS}

\section{NRC Reference Material}

As of November 1999, you may electronically access NUREG-series publications and other NRC records at NRC's Public Electronic Reading Room at www.nrc.gov/reading-rm/adams.html. Publicly released records include, to name a few, NUREGseries publications; Federal Register notices; applicant, licensee, and vendor documents and correspondence; NRC correspondence and internal memoranda; bulletins and information notices; inspection and investigative reports; licensee event reports; and Commission papers and their attachments.

NRC publications in the NUREG series, NRC regulations, and Title 10, Energy, in the Code of Federal Regulations may also be purchased from one of these two sources.

1. The Superintendent of Documents

U.S. Government Printing Office

P. 0. Box 979050 St. Louis, MO 63197-9000

http://bookstore.gpo.gov

1-866-512-1800 or, locally, 202-512-1800

2. The National Technical Information Service Springfield, VA 22161-0002

http://www.ntis.gov/ .

1-800-533-6847 or, locally, 703-805-6000

A single copy of each NRC draft report for comment is available free, to the extent of supply, upon written request as follows:

Address: Office of Administration

Reproduction and Distribution

Services Section

U.S. Nuclear Regulatory Commission

Washington, DC 20555-0001

E-mail: DISTRIBUTION@nrc.gov

Facsimile: $301-415-2289$

Some publications in the NUREG series that are posted at NRC's Web site address

http://www.nrc.gov/reading-rm/doccollections/nuregs/ are updated periodically and may differ from the last printed version. Although references to material found on a Web site bear the date the material was accessed, the material available on the date cited may subsequently be removed from the site.

\section{Non-NRC Reference Material}

Documents available from public and special technical libraries include all open literature items, such as books, journal articles, and transactions, Federal Register notices, Federal and State legislation, and congressional reports. Such documents as theses, dissertations, foreign reports and translations, and non-NRC conference proceedings may be purchased from their sponsoring organization.

Copies of industry codes and standards used in a substantive manner in the NRC regulatory process are maintained at-

The NRC Technical Library

Two White Flint North

11545 Rockville Pike

Rockville, MD 20852-2738

These standards are available in the library for reference use by the public. Codes and standards are usually copyrighted and may be purchased from the originating organization or, if they are American National Standards, from-

American National Standards Institute 25 West $43^{\text {rd }}$ Street

New York, NY 10036

http://www.webstore.ansi.org/

$1-212-642-4900$

The NUREG series comprises

(1) technical and administrative reports and books prepared by the staff (NUREG-XXXX) or agency contractors (NUREG/CR-XXXX), (2) proceedings of conferences (NUREG/CP-XXXX),

(3) reports resulting from international agreements (NUREG/IA-XXXX),

(4) brochures (NUREG/BR-XXXX), and

(5) compilations of legal decisions and orders of the Commission and Atomic and Safety Licensing Boards and of Directors' decisions under Section 2.206 of NRC's regulations (NUREG-0750). 
This page intentionally left blank 


\section{Section 6 GLOSSARY}

Activity or radioactivity: The rate of radioactive decay of a radionuclide, measured in the traditional unit of the curie $(\mathrm{Ci})$ or the international standard unit of the becquerel $(\mathrm{Bq})$.

Background (radiation): Radiation from cosmic sources; naturally occurring radioactive material, including radon (except as a decay product of source or special nuclear material); and global fallout as it exists in the environment from the testing of nuclear explosive devices and from past nuclear accidents such as Chernobyl that contribute to background radiation and are not under the control of the licensee. Background radiation does not include radiation from source, byproduct, or special nuclear materials regulated by the Nuclear Regulatory Commission.

Effluent discharge, radioactive discharge: The portion of an effluent release that reaches an unrestricted area.

Effluent release, radioactive release: The emission of an effluent.

Exposure pathway: A mechanism by which radioactive material is transferred from the (local) environment to humans. There are three commonly recognized exposure pathways: inhalation, ingestion, and direct radiation.

Fission and activation gases: The noble (chemically non-reactive) gases formed from the splitting (fission) of the uranium-235 isotope in a nuclear reactor or the creation of radioactive atoms from non-radioactive atoms (activation) by the capture of neutrons or gamma rays that were released during the fission process.

Gaseous effluents: Airborne effluents.

lodines/Halogens: The measured radioactive isotopes of iodine or of other non-metal elements in group 17 of the Periodic Table of Elements. Licensees might report any combination of the iodine isotopes $\mathrm{I}-131, \mathrm{I}-132, \mathrm{I}-133, \mathrm{l}-134$, and $\mathrm{l}-135$, as well as other halogens such as bromine$82(\mathrm{Br}-82)$.

Maximum exposed individual: Individuals characterized as maximum with regard to food consumption, occupancy, and other usage of the region in the vicinity of the plant site. As such, they represent individuals with habits that are considered to be maximum reasonable deviations from the average for the population in general. Additionally, in physiological or metabolic respects, the maximum exposure individuals are assumed to have those characteristics that represent the averages for their corresponding age group in the general population. 
Member of the public (10 CFR 20): Any individual except when that individual is receiving an occupational dose.

Monitoring: The measurement of radiation levels, concentrations, surface area concentrations or quantities of radioactive material and the use of results of these measurements to evaluate potential exposures and doses.

Noble gas: One of six noble gases (helium, neon, argon, krypton, xenon and radon) with an oxidation number of 0 that prevents it from forming compounds readily. All noble gases have the maximum number of electrons possible in their outer shell ( 2 for Helium, 8 for all others), making them stable.

Particulates: Radioactive materials entrained in the gaseous effluent that are not included in any other effluent category.

Site boundary: That line beyond which the land is neither owned, nor leased, nor otherwise controlled by the licensee.

Tritium: The radioactive isotope of hydrogen $(\mathrm{H}-3)$. 